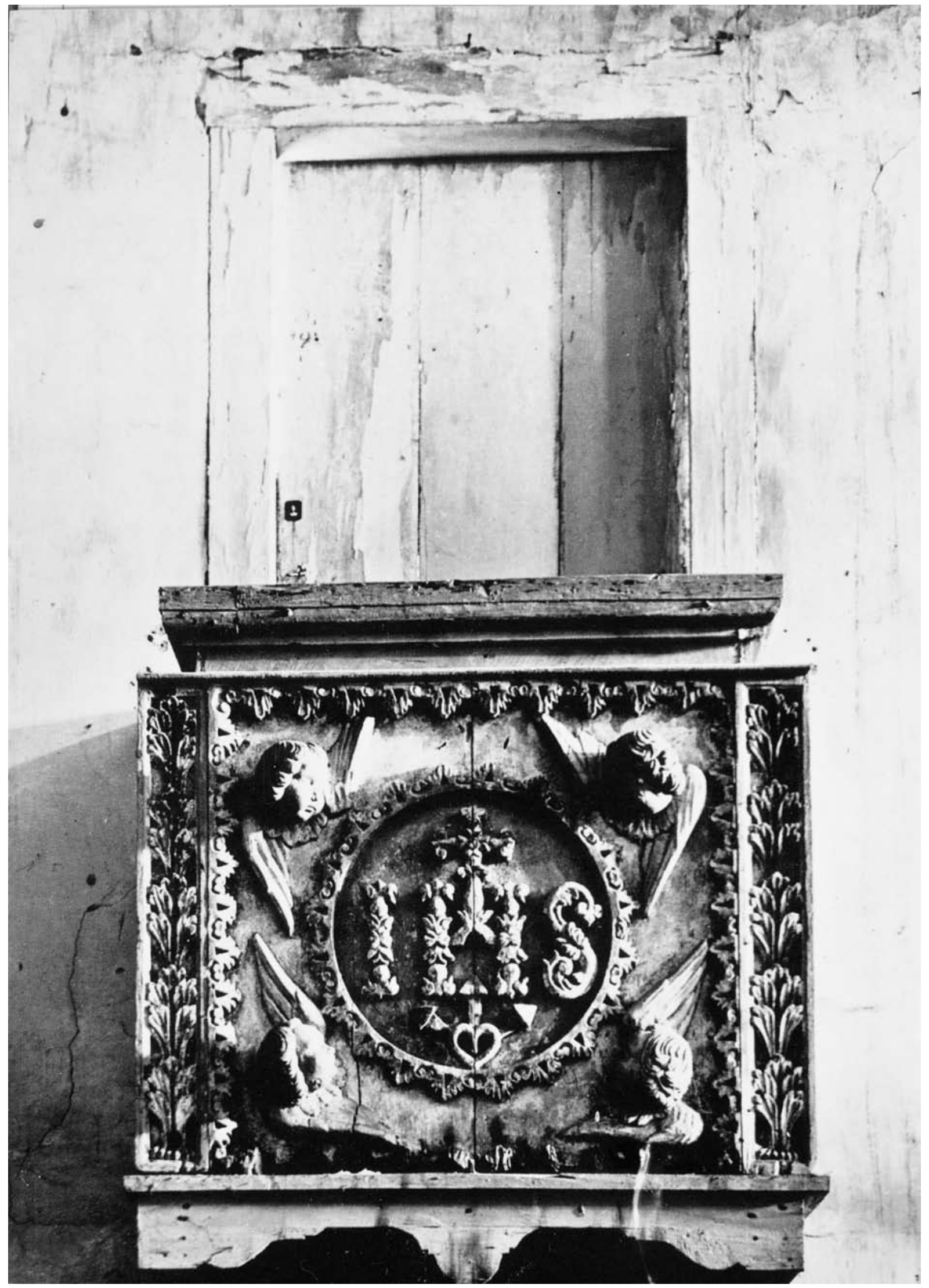




\section{Lúcio Costa}

\section{A arquitetura dos jesuítas no Brasil*}

palavras-chave: arquitetura no Brasil; Companhia de Jesus; barroco no Brasil; arte no Brasil dos séculos XVI - XVIII; igrejas; traçados urbanísticos

keywords: brazilian architecture; Society of Jesus; Baroque in Brazil; brazilian

art of the sixteenth to the eighteenth centuries; churches; urban design
Lúcio Costa aborda neste artigo as singularidades das construções jesuíticas no contexto brasileiro, defendendo que essas obras constituíram verdadeiramente nossa "antiguidade". O autor afirma que enquanto na Europa a Companhia se associava à exuberância das construções barrocas, aqui, suas intervenções eram marcadas por uma profunda sobriedade, não obstante deixando entrever um "sabor popular", que desfigurava desde sempre os padrões eruditos, configurando-se como experiências legítimas de recriações. $\mathrm{O}$ autor não deixa de atentar para o fato de que no Brasil as características arquitetônicas empreendidas nas obras dos jesuítas extrapolavam a esfera das edificações religiosas, repetindo-se nas demais construções do traçado urbano.

Lúcio Costa approaches, in this article, the singularities of the Jesuitical buildings in the Brazilian context, stating that such works constituted our true "antiquity". The author argues that, if in Europe the religious order was associated with the exuberance of Baroque, here its interventions were marked by a deep sobriety, nonetheless revealing a "popular flavor" that has been, since the beginning, transfiguring the classical canons, and, thus, becoming legitimate experiences of reinvention. The author pays attention to the fact that, in Brazil, the architectural features in the Jesuitical works surpasses the religious sphere, appearing in other urban buildings. 
*Texto originalmente publicado na Revista do

Serviço do Patrimônio Histórico e Artístico Nacional, Rio de Janeiro, n. 5, p. 105-169,

1941.
O considerável acervo de obras de arte que os padres da Companhia de Jesus nos legaram, fruto de dois séculos de trabalho penoso e constante, poderá não ser, a rigor, a contribuição maior, nem a mais rica, nem a mais bela, no conjunto dos monumentos de arte que nos ficaram do passado. É, contudo, uma das mais significativas.

A circunstância de se ter iniciado a ação da Companhia em fins do Renascimento, quando os primeiros sintomas do barroco já se faziam sentir, e de se desenvolverem, depois, os dois movimentos paralelamente, levou alguns críticos a pretenderem englobar sob a denominação comum de "arte jesuítica” todas as manifestações de arte religiosa dos séculos XVII e XVIII. Ora, as transformações por que passou a arquitetura religiosa, juntamente com a civil, durante esse longo período, obedeceram a um processo evolutivo normal, de natureza, por assim dizer, fisiológica: uma vez quebrado o tabu das fórmulas neoclássicas renascentistas, gastas de tanto se repetirem, ela teria mesmo de percorrer - independentemente da existência ou não da Companhia de Jesus - o caminho que efetivamente percorreu, até quando o barroco, por sua vez impossibilitado de renovação, teve de ceder o lugar à nova atitude classicista $\mathrm{e}$ já o seu tanto acadêmica de fins do século XVIII e começo do XIX.

Atribuir-se, pois, à designação de "arte jesuítica" uma tão grande amplitude é, evidentemente, incorreto. Mas não se trata tampouco de uma expressão furta-cor e vazia de sentido, como muitos supõem, só porque as manifestações de arte dos jesuítas apresentam formas diversas, de acordo com as conveniências e recursos locais e com as características de estilo próprias de cada período. Apesar dessas diferenças, por vezes tão sensíveis, e mesmo das aparentes contradições que se podem observar, diferenças e contradições que se acentuam à medida que as obras se vão afastando dos padrões mais definidos de fins do século XVI e da primeira metade do século XVII, apesar das mudanças de forma, das mudanças de material e das mudanças de técnica, a personalidade inconfundível dos padres, o "espírito" jesuítico, vem sempre à tona - é a marca, o cachet que identifica todas elas e as diferencia, à primeira vista, das demais. E é precisamente essa constante, que persiste sem embargo das acomodações impostas pela experiência e pela moda - ora perdida no conjunto da composição, ora escondida numa ou noutra particularidade dela - essa presença irredutível e acima de todas as modalidades de estilo porventura adotadas, é que constitui, no fundo, o verdadeiro "estilo" dos padres da Companhia.

Tratando-se de uma ordem nova e "diferente", livre de compromissos com as tradições monásticas medievais, e, por conseguinte, em situação particularmente favorável para se deixar impregnar, logo de início, do espírito moderno, pós-renascentista e barroco, é natural que tenha sido mesmo assim. 
Se isto é verdade com relação à obra internacional dos jesuítas em seu conjunto, para nós brasileiros, porém, a expressão "estilo jesuítico" tem um sentido mais limitado e preciso.

Com efeito, enquanto para os europeus, saturados de "renascimento", o falar-se em estilo jesuítico traz logo à lembrança, além das formas compassadas iniciais, as manifestações mais desenvoltas do barroco; enquanto para os hispano-americanos, onde a ação da Companhia prosseguiu ininterruptamente durante todo o século XVIII, a ideia da arte jesuítica abrange o ciclo barroco completo; para nós, no Brasil, onde a atividade dos padres, já atenuada na primeira metade do século, foi definitivamente interrompida em 1759, as obras dos jesuítas, ou pelo menos grande parte delas, representam o que temos de mais "antigo". Consequentemente, quando se fala aqui em "estilo jesuítico", o que se quer significar, de preferência, são as composições mais renascentistas, mais moderadas, regulares e frias, ainda imbuídas do espírito severo da Contra-Reforma.

A ideia de coisa decadente, de aberração, andou tanto tempo associada à noção de arte barroca, que, ainda hoje, muita gente só admira tais obras por condescendência, quase por favor.

Se algumas vezes os monumentos barrocos merecem realmente essa pecha de anomalias artísticas, a grande maioria deles - inclusive daqueles em que o arrojo da concepção ou o delírio ornamental atingem o clímax - é constituída por autênticas obras de arte, que não resultaram de nenhum processo de degenerescência, mas, pelo contrário, de um processo legítimo de renovação.

Com efeito, desde que os vários elementos de que se compõe cada uma das ordens gregas - as colunas, o entablamento, os frontões perderam as suas características funcionais primitivas, isto é, deixaram de constituir a própria estrutura do edifício, passando a representar, para os romanos, simplesmente elementos construtivos complementares e, para os artistas do Renascimento, apenas elementos de modenatura, independentes das necessidades construtivas reais, nenhuma razão mais justificava o apego intransigente às fórmulas convencionais e vazias de sentido então em vigor. Se o frontão já não era mais tão somente uma empena, a coluna um apoio, a arquitrave uma viga, mas simples formas plásticas de que os arquitetos se serviam para dar expressão e caráter às construções - por que não encarar de frente a questão e tratar cada um desses elementos como formas plásticas autônomas, criando-se assim novo alento de vida ao velho receituário greco-romano à bout de forces?

Não se trata, por conseguinte, de uma arte bastarda, como pretendem alguns, mas de uma nova concepção plástica, liberta dos preconceitos anteriores e fundada em princípios lógicos e sãos. 
Passando-se por alto sobre as interessantes teorias mais recentes que atribuem ao fenômeno barroco maior amplitude, definindo-o como atitude anticlássica permanente - interpretação que, a par da vantagem de acentuar o que há de fundamental na maneira barroca de ver e sentir, apresenta o grave inconveniente de estender desnecessariamente o campo de estudo, tornando-o difuso e complexo demais -, deve-se aqui entender por barrocas, dentro do critério histórico habitual, a maior parte das manifestações de arte compreendidas entre a última fase do Renascimento e o novo surto classicista de fins do século XVIII e, no Brasil, princípios do XIX.

A expressão "arte barroca" não significa, assim, apenas um estilo. Ela abrange todo um sistema, verdadeira confederação de estilos - uma commonwealth barroca, poder-se-ia dizer. Estilos perfeitamente diferenciados entre si, mas que mantêm uma norma comum de conduta em relação aos preceitos e módulos renascentistas.

No caso particular brasileiro, é na composição e talha dos retábulos de altar que se pode observar com nitidez essa extraordinária variedade de estilos peculiar ao barroco. Será melhor, porém, começarmos pelo exame do aspecto mais propriamente arquitetônico e construtivo dos monumentos, para depois então abordarmos a sua arquitetura interior.

Em vez de uma classificação sistemática por edifícios, por regiões, ou rigorosamente cronológica, as fotografias que acompanham este trabalho foram distribuídas conforme as afinidades de estilo ou de partido de composição. Esse critério apresenta, sobre os demais, a vantagem de grifar livremente as características próprias de um determinado período, de uma determinada técnica ou de uma determinada região, o que no caso, pareceu preferível. Vão também, fora do texto, numerosos pequenos desenhos esquemáticos que não têm outro objetivo senão o de procurar esclarecer e precisar melhor o sentido das palavras, a fim de tornar tanto quanto possível clara, mesmo aos leigos no assunto, a exposição da matéria.

Quando se estuda qualquer obra de arquitetura, importa ter primeiro em vista, além das imposições do meio físico e social, consideradas no seu sentido mais amplo, o "programa", isto é, quais as finalidades dela e as necessidades de natureza funcional a satisfazer; em seguida, a "técnica", quer dizer, os materiais e o sistema de construção adotados; depois, o "partido", ou seja, de que maneira, com a utilização desta técnica, foram traduzidas, em termos de arquitetura, as determinações daquele programa; finalmente, a "comodulação" e a "modenatura", entendendo-se por isto as qualidades plásticas do monumento.

O programa das construções jesuíticas era relativamente simples. Pode ser dividido em três partes, correspondendo cada uma destas a uma determinada utilização: para o culto, a igreja com o coro e a sacristia; para o 
trabalho, as aulas e oficinas; para residência, os "cubículos", a enfermaria e mais dependências de serviço, além da "cerca", com horta e pomar.

Sendo o objetivo da Companhia a doutrina e catequese, a igreja devia ser ampla, a fim de abrigar número sempre crescente de convertidos e curiosos e localizada, de preferência, em frente a um espaço aberto - um terreiro - onde o povo se pudesse reunir e andar livremente, não se prevendo, o mais das vezes, a construção ordenada de casas em volta dessa praça. É que, ao contrário do que se observa nas missões do sul, onde, como se verá depois, cada núcleo jesuítico constituía por si mesmo o "povo”, isto é, a cidade, os nossos principais colégios faziam parte de organizações urbanas distintas, ou então, quando sucedia a algum dos numerosos aldeamentos formados pelos padres, tomar corpo - como foi o caso de São Paulo de Piratininga, por exemplo - ele era logo repartido com as demais ordens religiosas e as autoridades civis. Assim, mais modesto e menos independente, o programa jesuítico brasileiro não comportava os traçados urbanísticos integrais tão característicos das missões da Província do Paraguai, das quais nos ficaram, por bem dizer, de quebra, os chamados Sete Povos das Missões.

A conhecida descrição quinhentista do colégio construído pelo arquiteto Francisco Dias, na Bahia, mostra claramente o programa seguido e indica com minúcia o conteúdo de cada um dos "quartos" da "quadra" e a respectiva orientação:

Tem de novo feito um claustro de pedra e cal e no quarto da parte de Leste, fica a igreja e a sacristia; a igreja é razoável, bem acabada, com seu coro, é bastante por agora para a terra, e bem ornada de ricos ornamentos [...] O outro quarto da parte do Sul tem por cima a capela e enfermaria de boa grandura, por baixo despensa e adega. O quarto da parte do Poente tem 19 câmaras: nove por cima e por debaixo dez com as janelas grandes que fazem cruz nos corredores. O quarto da parte de Nordeste tem sete câmaras por cima e seis por debaixo: todas são forradas de cedro, e amplas mais que as de Coimbra, os portais de cantaria, e é edifício bem acomodado, exceto que está por aperfeiçoar e forrar os corredores e guarnecer.

Já se deu impropriamente a essa expressão "forradas de cedro", referente às câmaras, o sentido de revestimento de paredes, à guisa de boiserie, quando, na verdade, não pode senão significar a forração comum dos tetos.

Quanto à técnica, excluídas as primeiras construções sumárias de cobertura vegetal, "de pouca dura" - como diziam, então, os padres - houve uma primeira série de edificações ainda provisórias, estruturas de madeira e barro de mão, quase sempre assobradadas, com compartimentos forrados e cobertura de telha. As referências a umas e outras, nas cartas, nas crônicas etc., são numerosas e muitas delas já pareciam "velhas" quando, de 1583 a 1585, o padre Cristóvão de Gouveia as visitou. Não eram, porém, tais cons- 
truções tão precárias como se tem dado a entender. Anchieta, por exemplo, referindo-se à área cultivada do primitivo Colégio de Olinda, diz o seguinte: “ainda que grande está toda cercada de parede de tijolo..."; e tem "duas ruas de pilares de tijolo com parreira”, acrescenta Fernão Cardim. Por onde também se conclui, fato este importante, que o emprego do tijolo em Pernambuco, ao contrário do que se tem afirmado, é anterior, de muito, ao domínio holandês.

As instruções de Roma com referência a construções eram, porém, no sentido de se atender à "perpetuidade - porque ainda que custe mais, sai mais barato". Aquelas estruturas provisórias foram, pois, substituídas, logo que as circunstâncias o permitiram e muitas vezes ainda no primeiro século, por construções já de caráter definitivo, de taipa de pilão ou de pedra e cal, dependendo a preferência dos recursos e das conveniências locais. As duas técnicas eram empregadas contemporaneamente. Onde houvesse bom barro e pedra e cal fossem difíceis de obter, recorria-se à taipa de pilão. Em São Paulo, por exemplo, fora do litoral.

Essas estruturas, em que as paredes são formadas por camadas sucessivas de barro apiloado, distinguem-se das de alvenaria de pedra pelos contornos menos definidos e precisos e pelo aspecto acachapado, conforme se pode observar no oitão da preciosa capelinha paulista de Santo Antônio, no Município de São Roque (fig. Ia). O espesso pranchão, fazendo de verga sobre a janela, é solução peculiar às construções de terra socada, embora também empregada nas de alvenaria de pedra, quando o enquadramento dos vãos não pudesse ser de cantaria, como ocorre, por exemplo, na porta travessa da igreja de Reritiba, hoje cidade de Anchieta, no Espírito Santo.

Na capela tão simpática de São Miguel, daquela mesma região de São Paulo (fig. 17), o aspecto mais leve e gracioso resulta do alteamento da nave com paredes de adobe, material muito empregado nas reformas e acréscimos do século XVIII, e escoramento interno de madeira. O feitio primitivo desta velha capela de 1622 - contemporâneo do portal e da peça valiosa que é a grade de separação do presbitério (fig. 17) - seria, acrescida de alpendre, o das capelas típicas de aldeia, como a de Carapicuíba (fig. 12), construção também de taipa, embora posterior de um século, pois data de 1735, e onde ainda se conservam, na terça decorada da sacristia, vestígios de mão de obra indígena (fig. 12).

Outro traço característico imposto pela técnica são os grandes beirais, precaução esta indispensável - já que não havia calhas - para evitar que a água despejada dos telhados fosse aos poucos desagregando o barro das paredes e comprometendo assim, com o tempo, a estabilidade do edifício.

Quanto às construções ditas de "pedra e barro", como, por exemplo, a igreja do Colégio de São Paulo (fig. 28), representavam, de 
certo modo, um compromisso entre essa técnica e a de pedra e cal.

Ao contrário do que se tem categoricamente afirmado, as edificações em alvenaria de pedra - tanto religiosas como civis - já eram bastante comuns na segunda metade do primeiro século. Foram várias as construções jesuíticas, igrejas e colégios, então feitas com essa técnica.

Tomé de Sousa, em sua carta de $1^{\circ}$ de junho de 1553 , descreve São Vicente com "hua igreja muito honrrada e honrradas casas de pedra e call com um collegio dos Irmãos de Jhesus", o que faz presumir fosse a igreja, ela também, de pedra e cal. Ora, essa igreja não podia ser outra senão a do próprio colégio, concluída no ano anterior e tão boa que, no dizer do padre Nóbrega, "até em Portugal não possuíam ainda então os Jesuítas outra melhor", porquanto a construção da nova matriz, edificada em substituição da primitiva, que o mar destruiu em 1542, só foi iniciada em 1559. E como, ainda hoje, a igreja do colégio - atual matriz - conserva, tanto externa como internamente, as proporções e o aspecto geral das igrejas mais antigas (fig. Ib), embora os vãos e o frontão datem do século XVIII, e o revestimento, a cobertura, o coro etc. tenham sido recentemente desfigurados - é bem possível que o seu arcabouço ainda seja o mesmo daquela primeira igreja referida pelo governador geral e assim descrita em carta do dia 20 de junho de 1552, pelo padre Nunes: "a igreja é a mais devota que há agora nesta costa. A capela é mui bem forrada e formosa, e um terço da igreja, por causa dos altares, é também forrado”. Mormente se levarmos em conta que muito antes do coup de grâce do aventureiro Cavendish, já São Vicente se estava despovoando e a decair e que ainda agora se conservam na igreja, conforme teremos ocasião de referir depois, quatro colunas e um sacrário, trabalhados no estilo característico dos altares jesuíticos do primeiro período.

A igreja de pedra e cal mandada construir por Mem de Sá, em Salvador, para o "mosteiro de Jesus", com capela-mor forrada "de painéis para se poder pintar de figuras com óleo avendo bom pintor que o saiba fazer", já estava concluída havia cinco anos quando ali chegou, em 1577, o irmão arquiteto Francisco Dias, com a incumbência de projetar e dirigir a construção do novo colégio, o mesmo descrito por Cardim, nove anos depois, "todo de pedra e cal de ostra, que é tão boa como a de pedra de Portugal. Os cubículos são grandes, os portais de pedra, as portas d'angelim forradas de cedro”.

Era também construção do primeiro século e de pedra e cal a igreja destruída com o arrasamento do morro do Castelo, nesta cidade, igreja inaugurada em 1588, em substituição da primitiva, e que ainda conservava, quando demolida - demolição feita com desamor e sem os cuidados que no caso se impunham - o aspecto original (fig. 2). 
Nesta página, Fig. 2:

Frontespício da igreja

do antigo Colégio do

Rio de Janeiro e foto do

sacrário de um dos

altares colaterais da

mesma igreja.
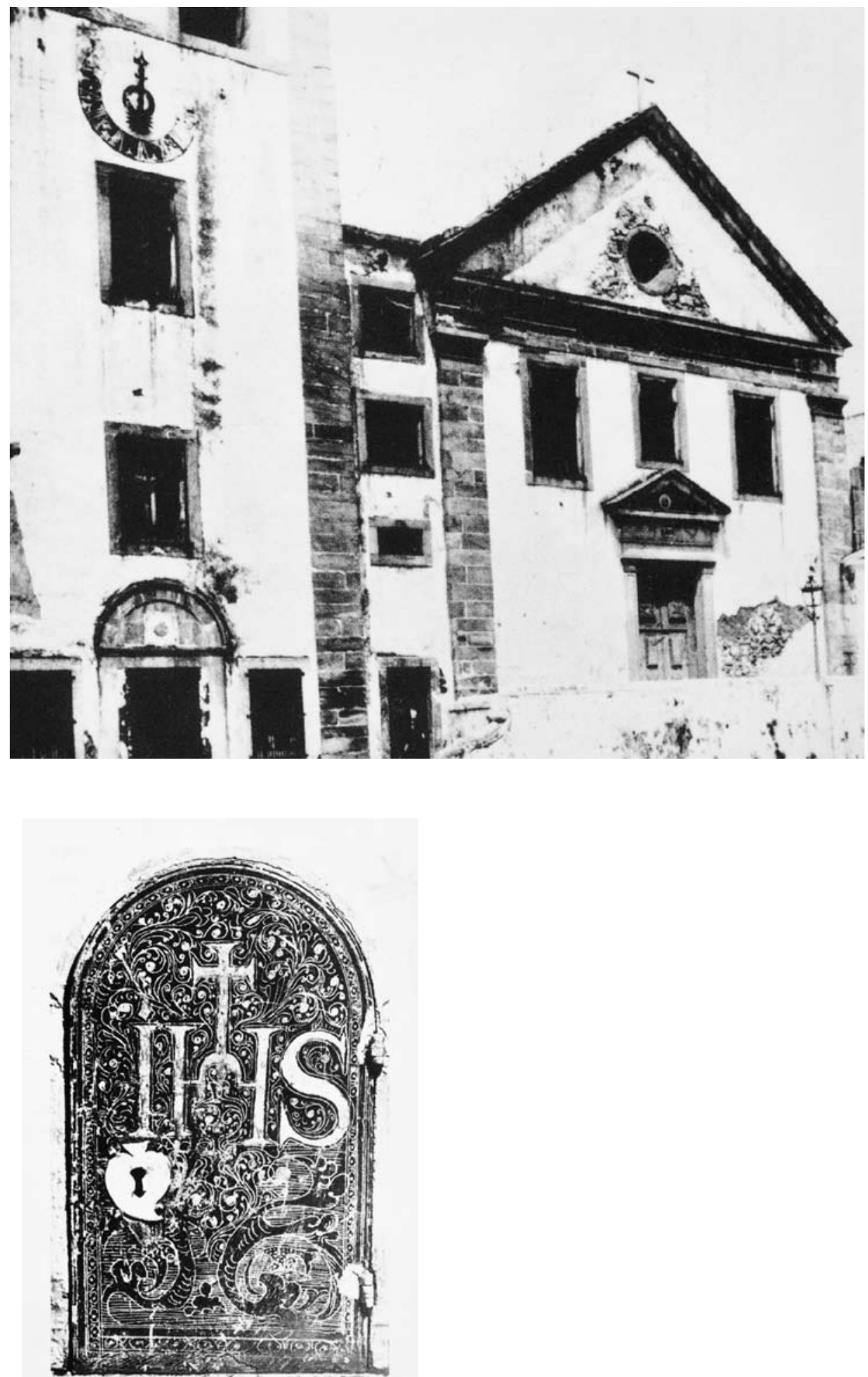
Fig. 3: Sacrário e pormenores do retábulo do altar-

mor da antiga igreja do

Colégio do Rio de Janeiro
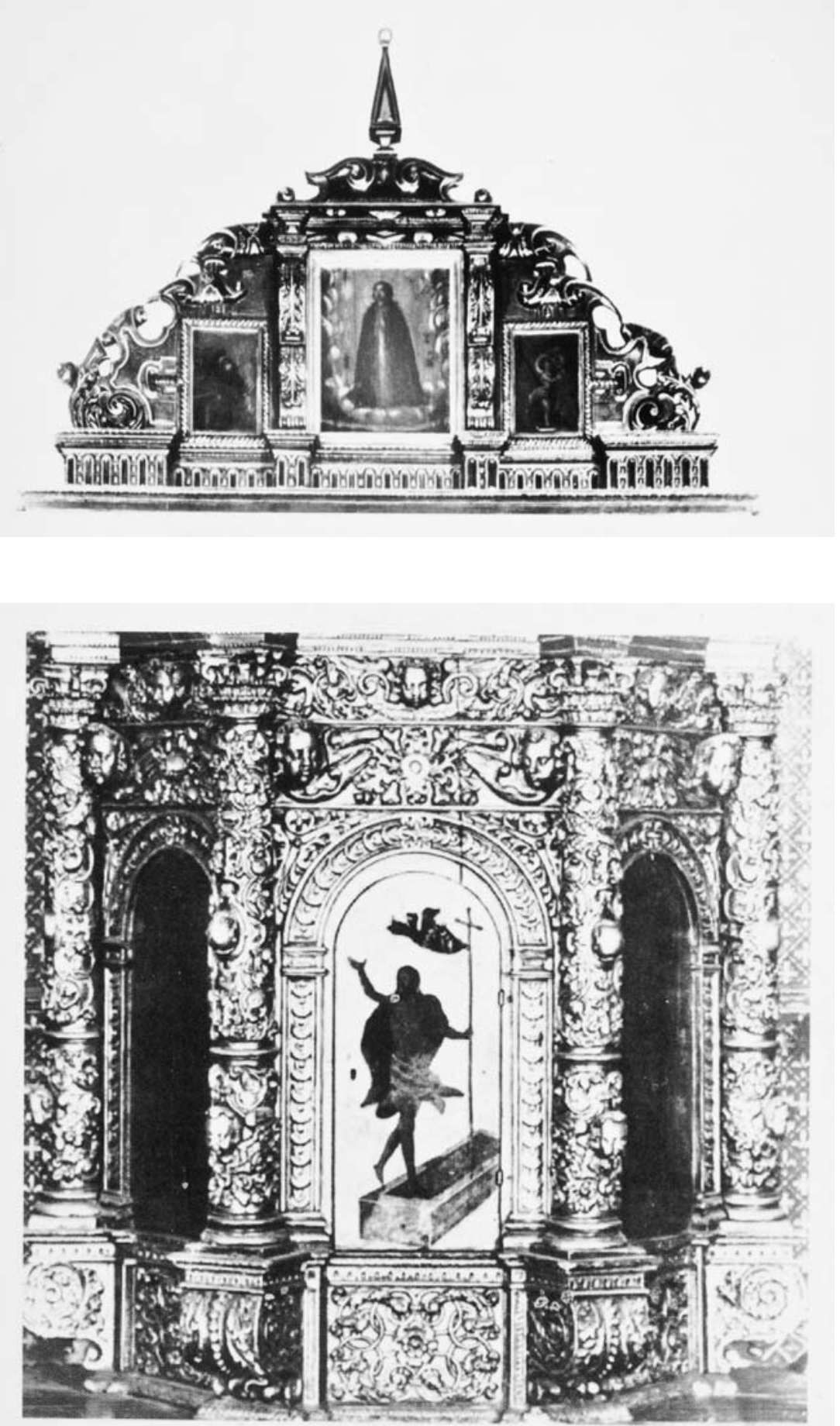
Fig. 4: Retábulo de um dos altares colaterais da antiga igreja do Colégio do Rio de Janeiro.

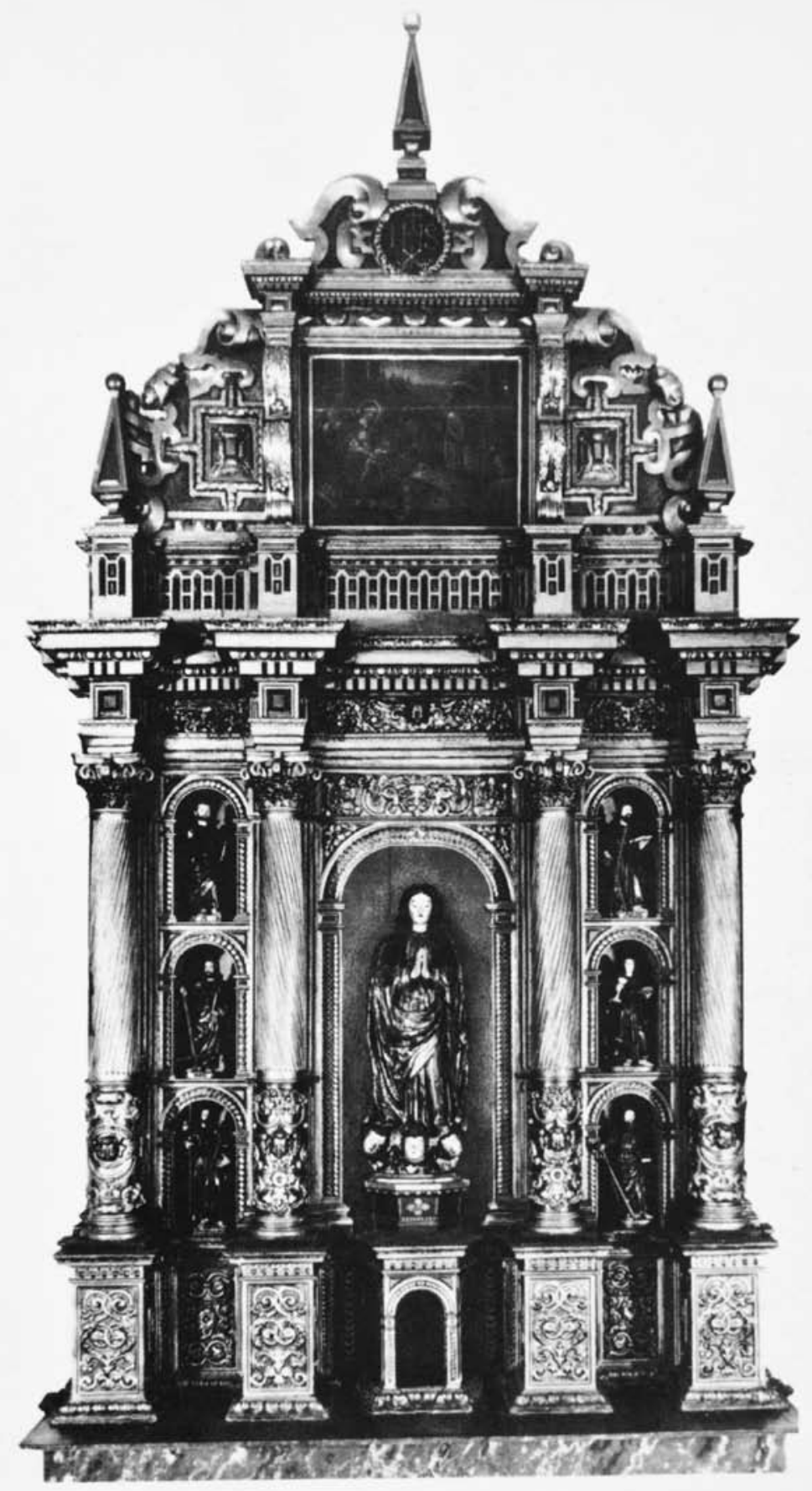


Fig. 5: Retábulo de um dos altares colaterais da antiga igreja da Graça, do antigo Colégio de Olinda e pormenor de um quadro de Franz Post, onde se vê o estado em que ficou a igreja depois do incêndio.
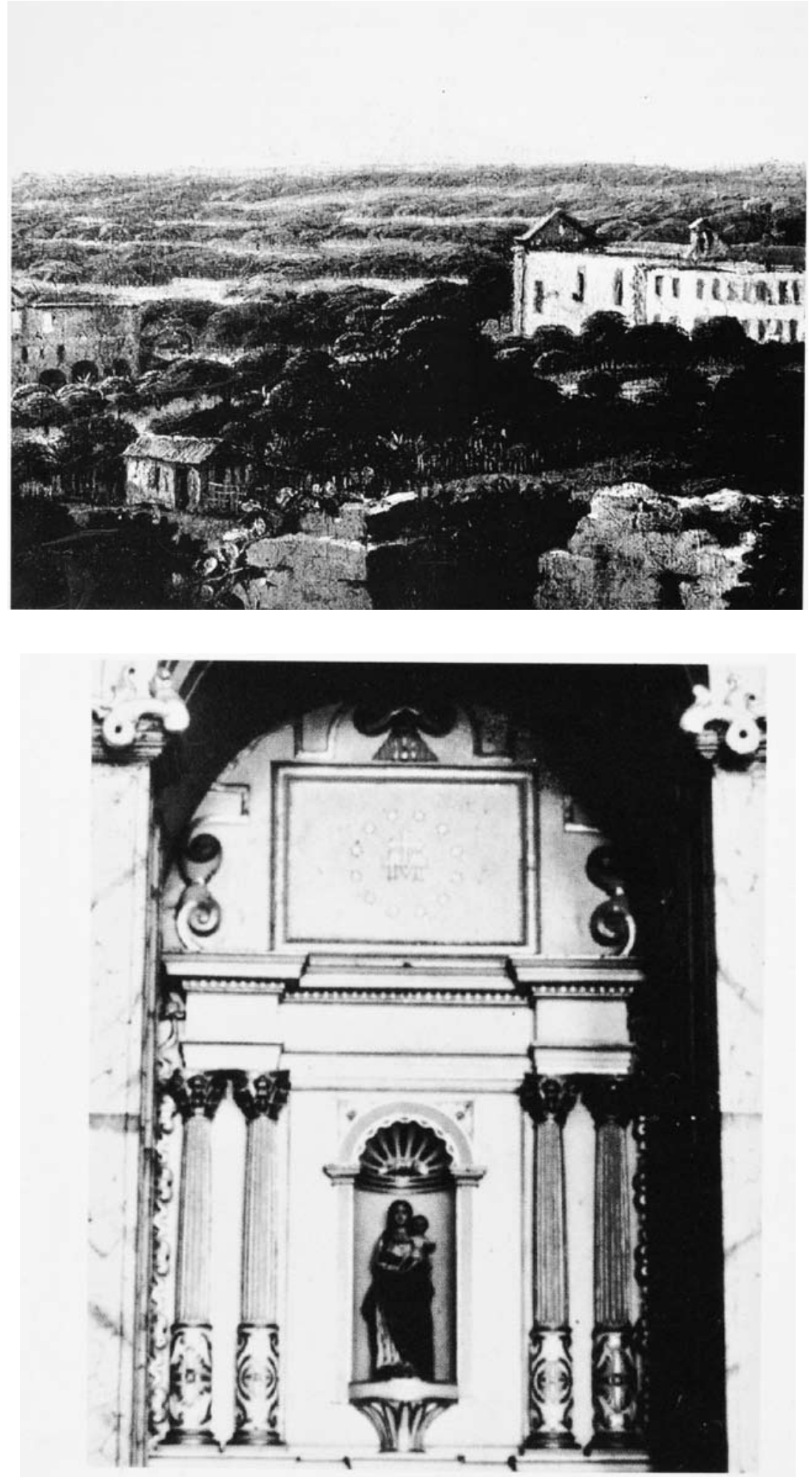
Finalmente, a nova igreja de N. Sra. da Graça, do Colégio de Olinda, cuja construção foi iniciada, em pedra e cal, logo após a inspeção do visitador, já em 1592 "estava coberta e pronta só faltava caiar", obedecendo o seu estilo, segundo informa o padre Pero Rodrigues, em 1597, "à traça de S. Roque".

Essa igreja quinhentista tem sido dada como "reduzida a cinzas" pelos holandeses, considerando-se o edifício atual uma reconstrução de fins do século XVII, destituída de maior interesse. Os estudos efetuados pelo Serviço do Patrimônio Histórico e Artístico Nacional mostram, entretanto, de forma inequívoca, que essa igreja é, de fato, a primitiva. Com efeito: $1^{\circ}$ ) os altares colaterais são contemporâneos da construção de fins do século $\mathrm{XVI}$, conforme se poderá constatar adiante, quando tratarmos com mais vagar da arquitetura interna das igrejas jesuíticas; $2^{\circ}$ ) o risco da igreja, tanto pelo seu interior como pela fachada, baseia-se, efetivamente, na "traça" da igreja de São Roque, da Casa Professa dos Jesuítas, em Lisboa, cujo frontispício - a única parte do prédio que sofreu com o terremoto - foi, ao que parece, reconstruído com aproveitamento do material primitivo (fig. Ic); $3^{\circ}$ ) no panorama de Olinda, de Franz Post, aqui reproduzido (fig. 5), observa-se muito claramente que os danos causados pelo incêndio - da mesma forma que em Lisboa com o terremoto - não foram de molde a desmantelar o edifício. O fogo, ateado, é de presumir-se, no altar-mor, que, este sim, desapareceu, teria passado ao forro e ao madeiramento da cobertura; daí ao coro e às janelas da fachada principal, janelas cujos vãos foram recompostos já em desacordo com o estilo da construção quinhentista. A preservação dos altares colaterais explica-se muito naturalmente, porquanto, pela disposição da planta, ficam isolados do altar-mor e resguardados ao fundo de dois arcos de alvenaria de pedra com pés-direitos e arquivoltas de cantaria (fig. 5).

Esta igreja de Olinda, projetada pelo arquiteto jesuíta Francisco Dias, um dos colaboradores de Filipe Tersi - o arquiteto levado de Roma para Lisboa pelos jesuítas, especialmente para construir a igreja de São Roque - é, pois, a única igreja jesuítica quinhentista, com pedigree, ainda existente no Brasil, uma vez que a autenticidade do arcabouço da de São Vicente, que de qualquer forma não terá filiação tão definida, ainda não está, apesar dos indícios, comprovada ${ }^{1}$.

Passemos agora a considerar, tanto no conjunto dos monumentos como nos seus pormenores, o partido, ou melhor, os partidos de preferência

1. Já se achava em provas este trabalho, quando dona Maria de Lourdes Pontual - funcionária do SPHAN, incumbida pelo diretor do Serviço de estudar mais de perto esse caso da igreja da Graça -, submeteu à apreciação da Seção Técnica a adotados - quando não, criados - pelos arquitetos jesuítas, ou arquitetos leigos a serviço da Companhia de Jesus.

O partido arquitetônico tradicionalmente empregado pelas ordens religiosas nos seus mosteiros e conventos, ou seja, o de dispor os vários corpos da construção em "quadra", como então se dizia, formando-se assim um ou mais pátios, foi mantido também pelos jesuítas. Convém, entretanto, 
admirável descrição da igreja de São Roque, de Lisboa, contida no tomo $2^{\circ}$ da Cronica da Companhia de Jesus, de Baltazar

Teles. Verifica-se, por esse valioso documento, que na igreja de Lisboa havia nichos laterais destinados aos confessionários e encimados por janelas ou tribunas, semelhantes, portanto, aos existentes na igreja de Olinda, nichos que foram mais tarde (Baltazar Teles escreve antes de 1642) desmanchados, embora "alguns a julgassem d'antes por mais engraçada" para se abrirem no lugar deles mais quatro capelas profundas, naturalmente já por influência da igreja de São Vicente de Fora, então em construção. Consequentemente, a igreja da Graça corresponde ainda à feição original da nova igreja de São Roque - o que mais acentua a importância histórica desse monumento -, ao passo que a do Salvador já corresponde à versão ampliada seiscentista. desde logo notar que, em consequência talvez da vida ativa dos padres, atividade esta decorrente do "espírito" mesmo da Companhia e da sua Regra, faltam quase sempre nesses pátios - nos colégios brasileiros, pelo menos aquela atmosfera de sossego e de recolhimento, peculiar aos claustros dos conventos das demais ordens religiosas.

Além do antigo Colégio da Bahia, de que já tratamos, e do de Belém do Pará, descrito por Bettendorf, são também dispostos em quadra, entre outros, o Colégio de Olinda, os do Espírito Santo e do Estado do Rio, o de Embu - este com pátio bem modesto - e, ainda, diferente de todos os demais pelo seu aspecto sombrio e pesado de praça-forte, o de Paranaguá.

Um dos "quartos" da quadra era sempre ocupado pela igreja, cujo frontispício, mantido no alinhamento do quarto contíguo, formava com este, em elevação, um plano só, correspondendo ao colégio uma linha horizontal contínua e ao corpo da igreja um frontão de empena, com a torre servindo de remate à composição (fig. Id). Essa disposição, clara e coerente, era geralmente adotada quando, de início, não fazia parte do programa a construção de uma segunda torre. O bem composto conjunto de Reis Magos (fig. 18) é uma das poucas exceções a esta norma.

Quando os planos previam a possibilidade de se vir a construir, futuramente, uma segunda torre, aquela que primeiro se fazia era a de ligação entre a ala do colégio correspondente ao terreiro e a igreja, como nos colégios do Castelo, no Rio de Janeiro e de São Paulo. Torres que, na maior parte das vezes, não foram concluídas ou nem mesmo sequer iniciadas, ou que só se fizeram depois da expulsão, muito mais tarde, sem se atender então, de qualquer forma, às características da construção primitiva; já não diremos quanto ao estilo - o que, aliás, nunca sucedia - mas quanto ao equilíbrio plástico da composição, como, por exemplo, na igreja já demolida do Colégio de Vitória (fig. Ie).

No que se refere à planta baixa das igrejas, o partido aqui adotado pelos jesuítas foi, quase exclusivamente, o de uma só nave. Apenas em dois casos, a documentação até agora coligida mostra solução diferente. Na igreja de São Pedro d'Aldeia (fig. 32), construção muito "pura”, tanto do ponto de vista técnico como plástico, onde se vê, na sua forma mais rudimentar, o partido de três naves tão apropriado às igrejas missioneiras (os esteios centrais, aliviando o peso da cobertura, permitem maior amplitude e daí a possibilida de de abrigar um maior número de fiéis) (fig. If) - e na da antiga Reritiba. Nesta, a sustentação do madeiramento da cobertura e consequente separação do corpo da igreja em três naves - ou pseudonaves - é feita por duas ordens de arcadas, disposição que parece ser a original; não só porque as colunas apresentam características de trabalho muito antigo, como também porque, considerando-se a largura desusada do corpo da igreja, a pouca 
Fig. I
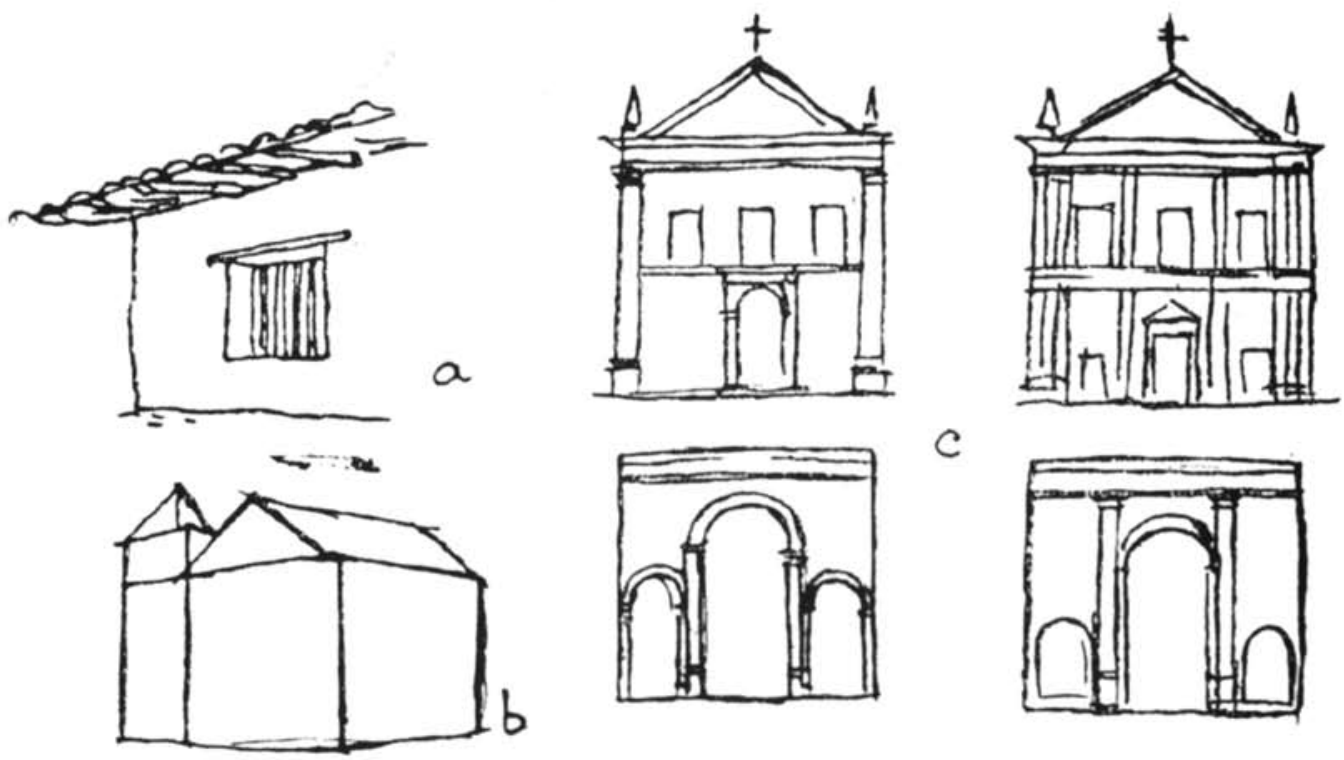

c
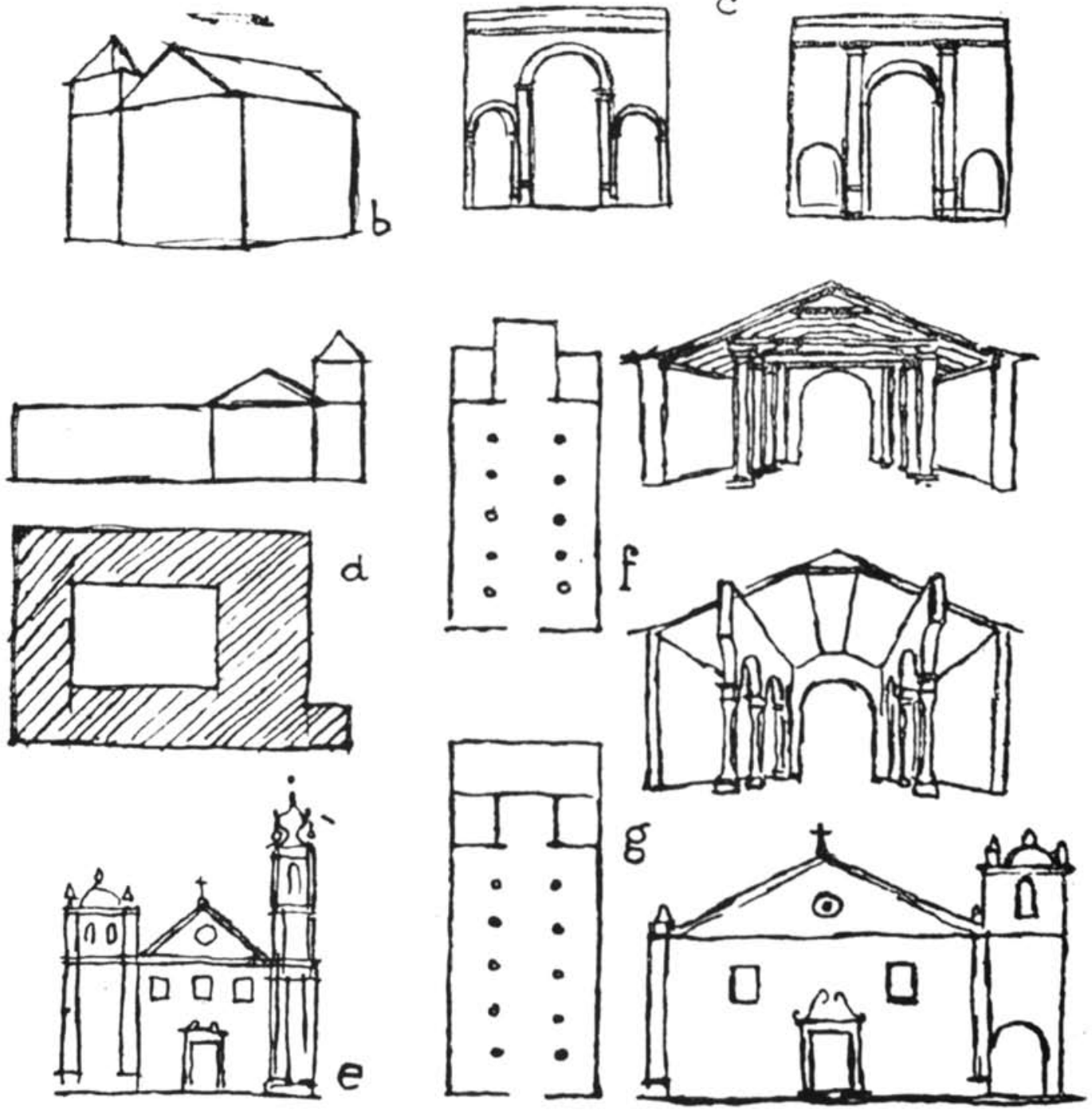
Fig. 6: Retábulo do altar-mor da igreja de

São Lourenço dos

Índios, em Niterói.
Fig. 7: Casticais da primitiva banqueta do altar-mor da igreja de São Lourenço dos Índios.

Fig. 8: Sacrário e uma das colunas do retábulo do altar-mor da igreja do antigo Colégio de São Vicente.
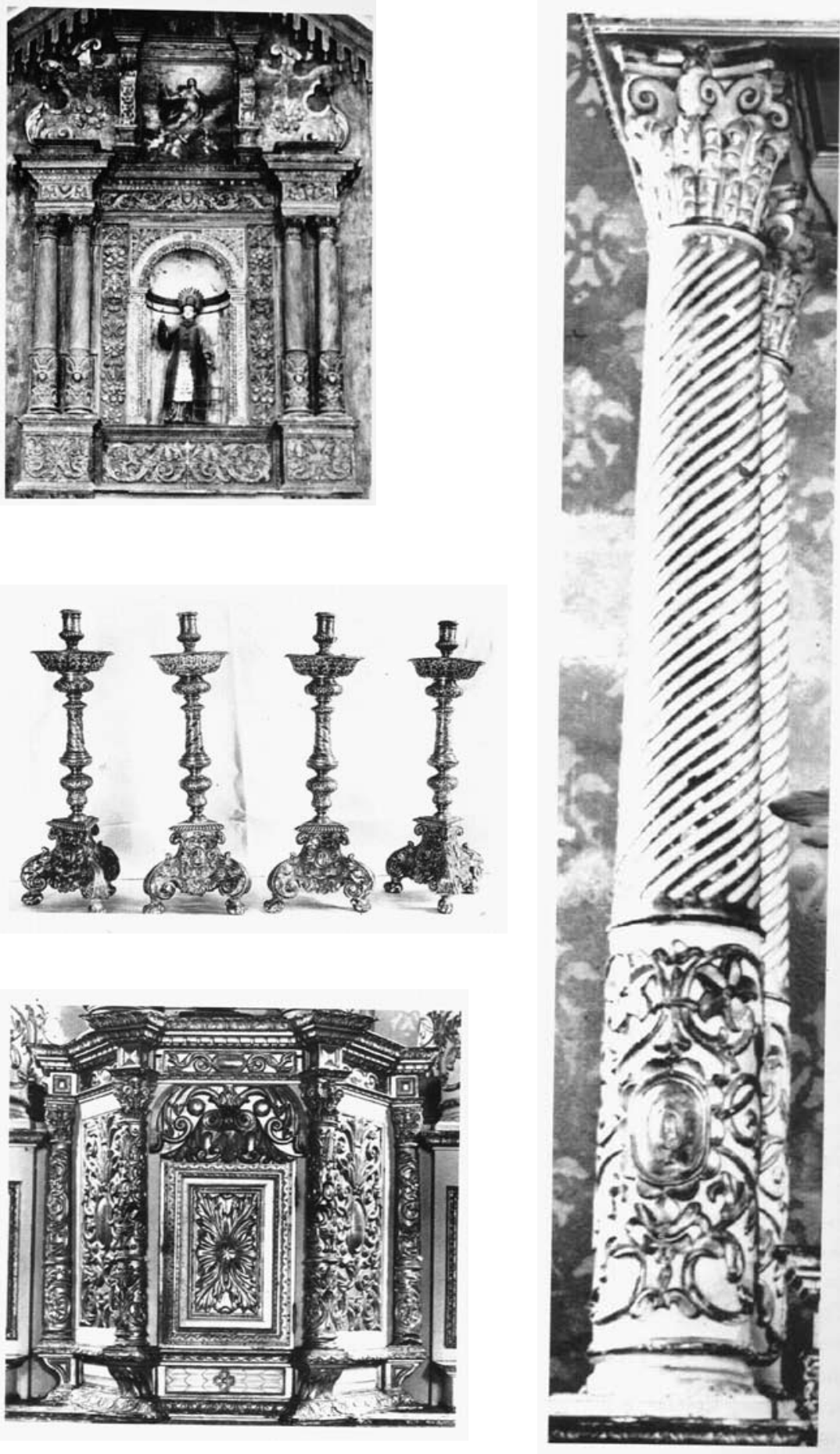
espessura das paredes dos oitões parece indicar não terem sido feitas para resistirem, sozinhas, aos esforços laterais resultantes do sistema de armação adotado na cobertura (fig. Ig). O que, aliás, não seria de estranhar - tratando-se, ao que parece, de uma igreja seiscentista - porquanto as três naves da velha Matriz de São Sebastião, no antigo morro do Castelo, aqui no Rio, embora já estivessem reformadas por ocasião da demolição, correspondiam, ainda à descrição da igreja quinhentista de Mem de Sá: "Fiz a Sé de três naves, também telhada e bem consertada".

O partido geral de uma só nave inclui, no caso das igrejas jesuíticas brasileiras, plantas de quatro tipos diferentes.

Primeiro o tipo mais singelo, que teria sido o das capelas rudimentares dos primeiros tempos e no qual a capela-mor e a nave constituem um mesmo corpo de construção dividido convencionalmente em duas partes por um arco "cruzeiro” (fig. IIa). Essa forma primária, hoje muito rara, é a que vamos encontrar na já referida capela de Santo Antônio, do segundo século, que, apesar da invocação e do fato de ser uma capela particular, não deixa contudo de ser, também, uma capela de inspiração e de gosto jesuíticos, conforme teremos ocasião de verificar depois. E ainda, possivelmente, na de Voturuna, de que só resta a parte correspondente à capela-mor, cujo retábulo - uma versão de sabor popular dos nobilíssimos retábulos jesuíticos do primeiro período - é, por essa mesma razão, uma peça de valor excepcional (fig. 13).

Depois o partido tão generalizado, próprio das igrejas mais antigas e daquelas que, embora relativamente recentes, obedeceram a um programa mais modesto de construção: igrejas onde aparecem perfeitamente diferenciadas a nave e a capela-mor propriamente dita, de largura e pé-direito menores (fig. IIb), partido claro e franco de composição, que depois se desenvolve em Minas Gerais.

O terceiro grupo reúne as igrejas cujo traçado corresponde a uma acomodação entre essa forma singela mais geral e o partido já o seu tanto complexo das igrejas maiores do século XVII. Nessas igrejas, mantêm-se ainda os três altares usuais do modelo anterior, com a particularidade, porém, de se criarem, também para os colaterais, pequenas capelas apropriadas, de maior ou menor profundidade, como no caso da igreja de Olinda, onde tais capelas formam conjunto com a capela-mor (fig. IIc). Nesta igreja, os dois nichos localizados acima dos arcos dessas capelas (fig. IId) parecem acréscimos ao traçado primitivo, contemporâneos da reforma do segundo século e, possivelmente, criados com o objetivo de nele se colocarem as imagens de Santo Inácio e São Francisco Xavier, já então canonizados, porquanto esse mesmo tema ocorre por várias vezes em igrejas jesuíticas desse período. Vamos, por exemplo, encontrá-lo na importante igreja do Seminário de Belém 
de Cachoeira, onde os nichos são em número de quatro, dois de cada lado do altar-mor (fig. IIe), e também em igrejinhas modestas, como a de Vinhais, no Maranhão (fig. IIf). Na igreja de Socorro, em Sergipe, os padres adotaram o partido, bem mais frequente, de dispor as duas capelas no sentido transversal, repetindo-se, assim, a velha norma de planta em cruz latina (fig. IIg). O arco de uma dessas capelas, em cantaria e ricamente ornamentado, parece único, no seu estilo, em todo o país (fig. 31).

Na do Colégio de São Luís, no Maranhão, o partido é o mesmo, embora, pelas proporções, esta igreja talvez se enquadrasse melhor entre as do último tipo - o das igrejas maiores seiscentistas, já influenciadas pelo padrão de planta então corrente da igreja jesuítica romana de Gesù. Pertencem ou pertenceram a esta categoria, além da igreja do Colégio do Salvador, espécie de "matriz" da Companhia, as de São Paulo de Piratininga e de Belém do Pará. Em vez dos três altares - caso mais geral nas igrejas do tipo anterior - contam-se aqui numerosos altares dispostos em capelas laterais, sendo que as duas mais próximas da capela-mor faziam-se quase sempre mais largas e mais altas, quando não também mais profundas, com aquele mesmo objetivo de marcar, em planta, o cruzeiro (fig. IIh).

Consideremos a seguir o aspecto propriamente plástico e de modenatura desses monumentos.

Na construção de suas igrejas os padres, embora acompanhassem, como os demais religiosos, a evolução normal do estilo de cada época, atuaram em numerosos casos como autênticos renovadores, apoiando e adotando as concepções artísticas mais modernas e "avançadas"; não somente com o barroco ainda classicista da primeira fase da Contra-Reforma, quando, fora da Itália, as formas ornadas do primeiro Renascimento ainda prevaleciam, como depois, na época de maior eloquência do estilo barroco, com as inovações, nem sempre aceitáveis, de alguns artistas, mesmo jesuítas.

Correspondendo grande parte das construções jesuíticas brasileiras definitivas ao período do domínio espanhol, - quando a personalidade obstinada e sombria de Filipe II já se desenhava, com tamanha nitidez, na arquitetura austera e despojada, quase penitente, do seu "palácio-convento" desmedido - nada mais natural que as construções da Companhia, conhecidas as ligações dela com o monarca, refletissem, nessa fase melhor que nas demais, também aqui, pelas suas proporções e modenatura, o gosto severo e frio próprio do estilo de Herrera, tanto mais que as dificuldades locais impunham mesmo à nossa arquitetura um certo comedimento.

Essas afinidades não se limitaram, porém, a influências de natureza assim tão vaga: tiveram uma origem bem mais precisa. É que Filipe II encontrara também em Portugal, na pessoa de Terzi - o arquiteto dos jesuítas - um artista da nova escola, capaz de lhe traduzir, de forma condigna, 

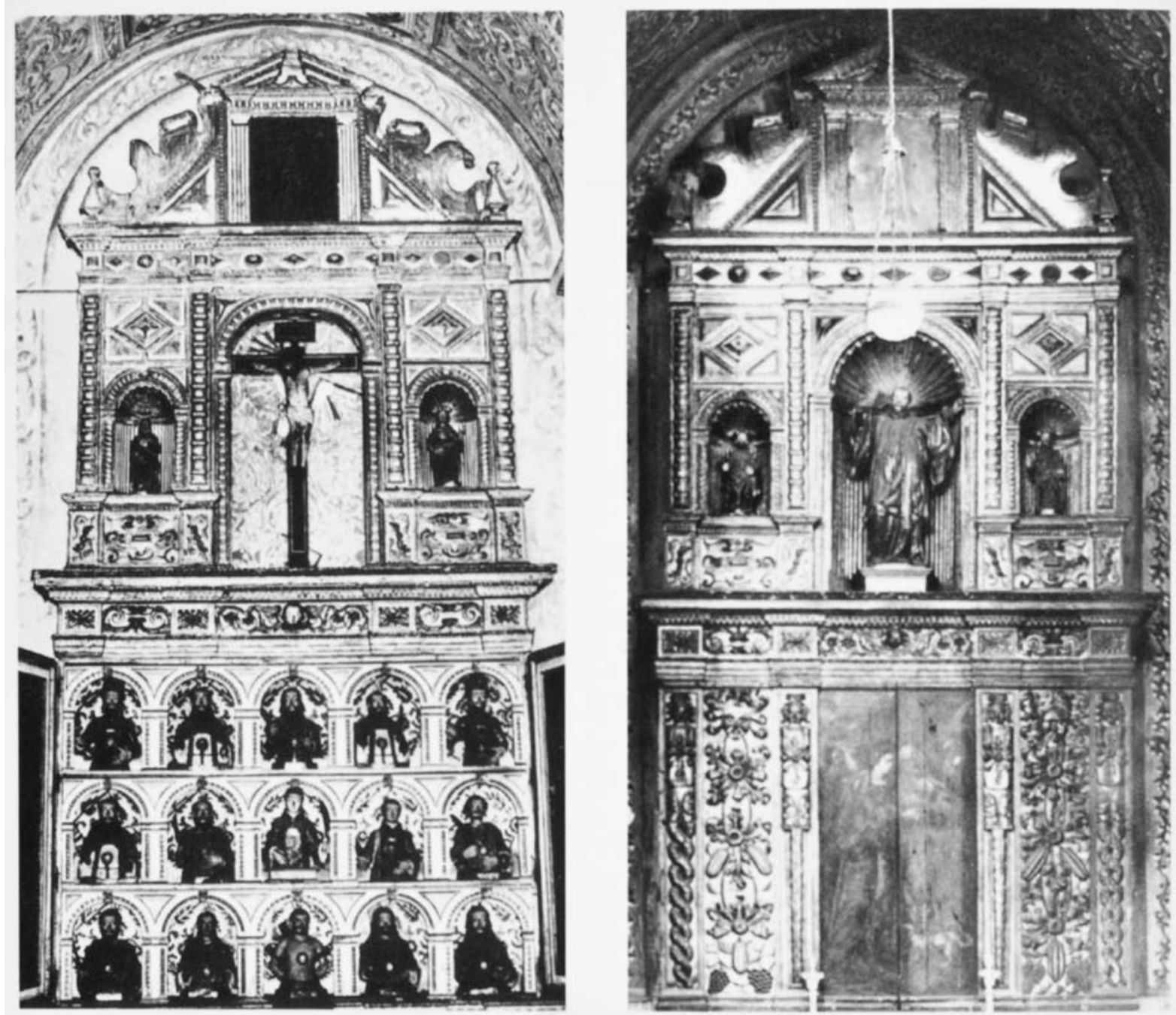

Fig. 9: Retábulo da capela dos Santos Mártires e das Virgens Mártires, na igreja do antigo Colégio da Bahia. 
Fig. II
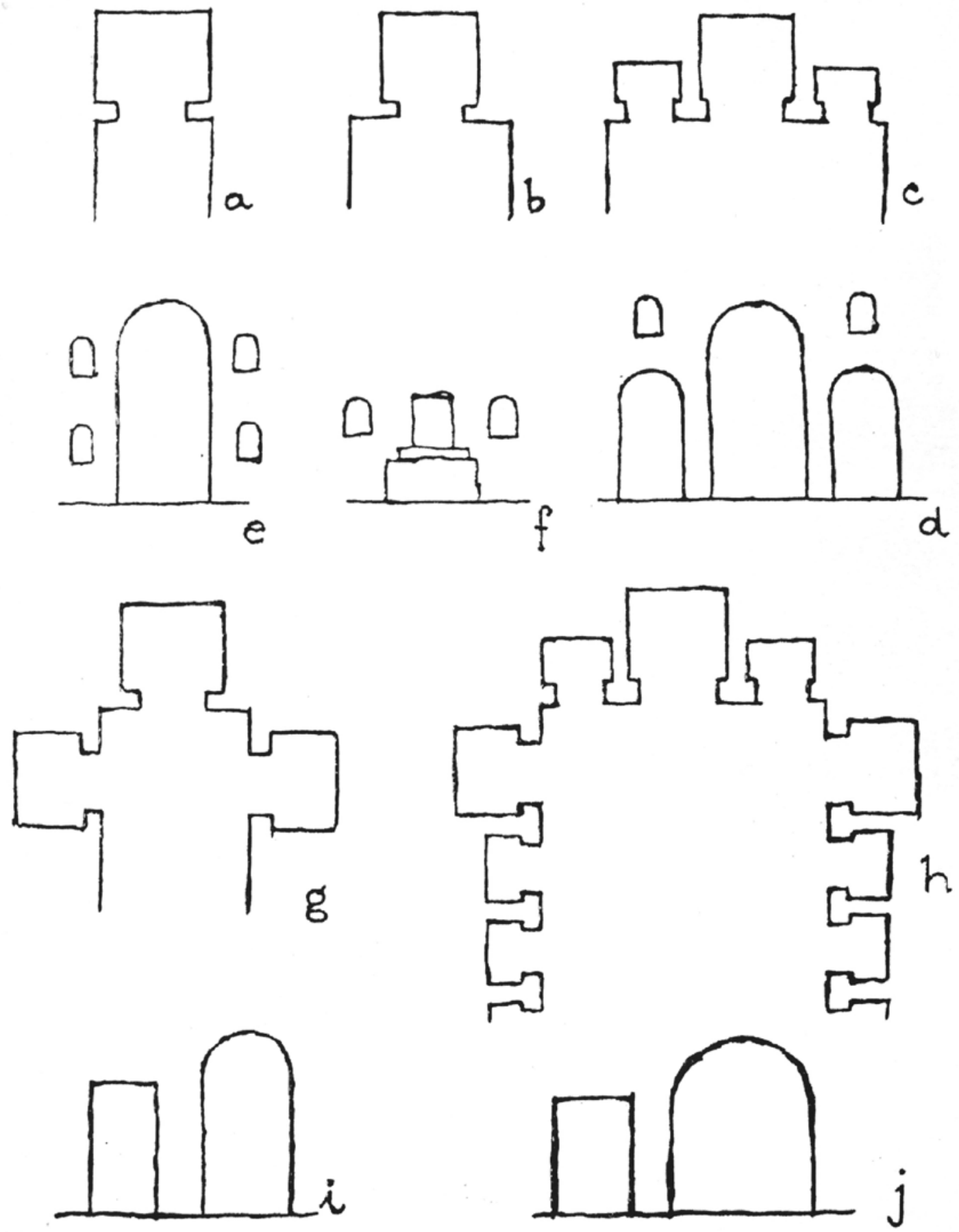
Fig. III
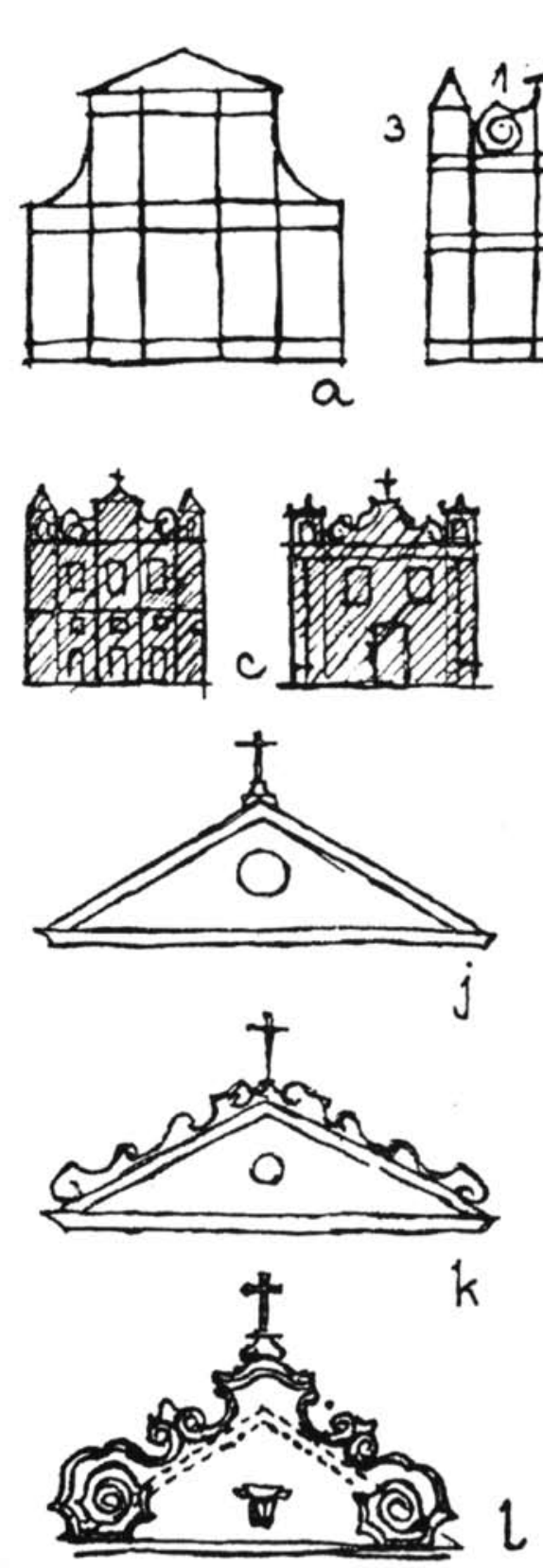
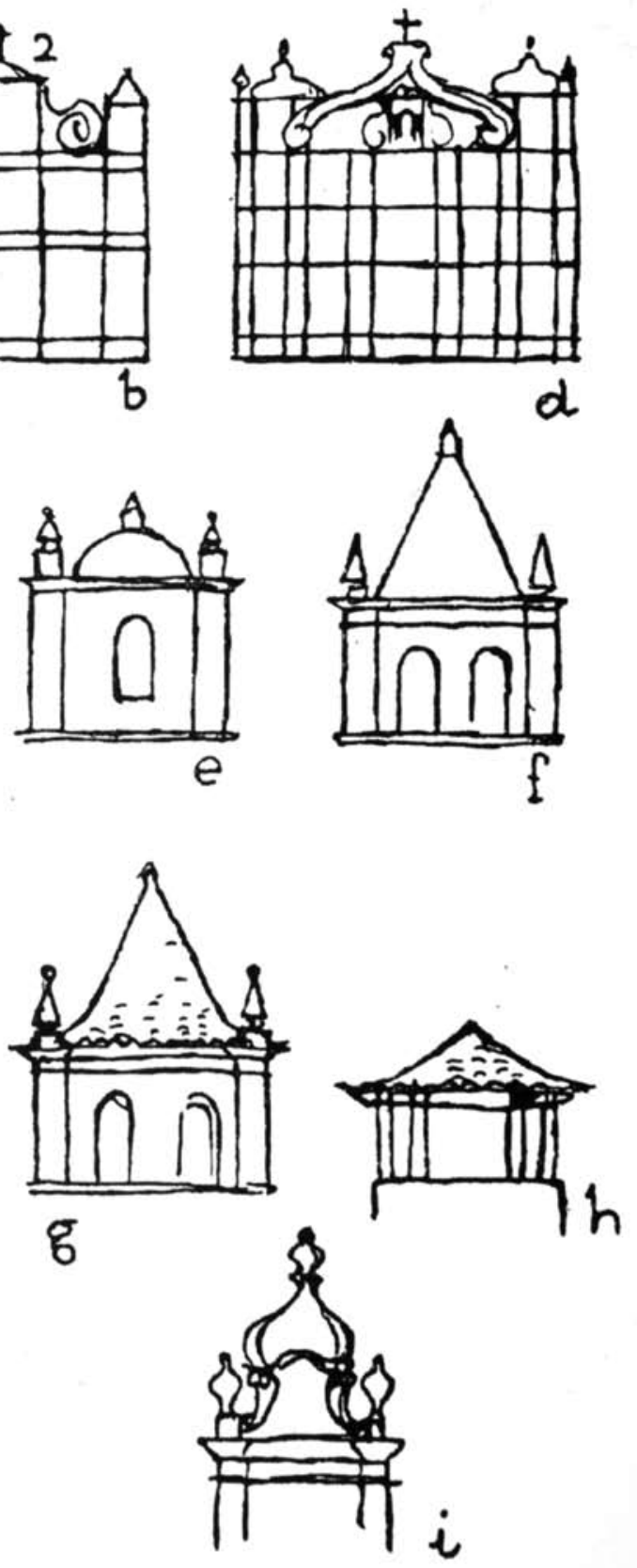
2. À vista das informações do padre Baltazar Teles, referidas na nota anterior, conclui-se não ter sido ainda esse primeiro risco, que presumimos houvesse feito o irmão Francisco Dias para a igreja baiana, o da igreja atual e sim outro, mais conforme com tanto a altivez e orgulho congênitos, como o puro ideal de paladino tenaz da Contra-Reforma. Confiou, efetivamente, o rei a esse artista, as obras dos Paços da Ribeira e apôs, em 1590, o seu visto às famosas plantas da igreja de São Vicente de Fora, na mesma cidade de Lisboa.

Ora, foi precisamente esse estilo sóbrio e de formas geométricas definidas, de Herrera em Madri e de Terzi em Lisboa, estilo ali, então, "ultramoderno" e que destoava violentamente da atmosfera local, saturada ainda de reminiscências manuelinas e platerescas, que veio para o Brasil quinhentista, trazido de primeira mão - novo em folha - pelo arquiteto Francisco Dias, colaborador de Terzi na construção de São Roque, conforme ficou dito anteriormente. Estilo cujas características aristocráticas ainda se podem observar nos três arcos de pedra, o da capela-mor e os colaterais, da igreja do antigo Colégio de Olinda, infelizmente recobertos com obra de talha mais recente, e que, até há pouco, também aqui no Rio podíamos apreciar no elegante portal da igreja do Castelo (figs. 5 e 2).

A presença de um arquiteto profissional de sua categoria no Brasil daquele tempo foi sem dúvida decisiva, não só no sentido de fixar, de forma definitiva e logo de início, as características de estilo próprias da nossa arquitetura jesuítica, como também no de influir nas construções contemporâneas não jesuíticas.

Aliás, a própria igreja seiscentista atual do Colégio da Bahia, cuja planta obedece igualmente à de São Roque, deve ser baseada em risco de autoria dele, porquanto, vindo ao Brasil especialmente para projetar e dirigir a construção daquele colégio, e já encontrando, feita de novo por Mem de Sá para os padres, uma igreja relativamente modesta, que ficou formando um dos corpos da quadra desse colégio definitivo - isto provisoriamente, pois que era apenas "grande bastante por agora" - por certo terá incluído no seu plano de conjunto, como não podia deixar de o fazer, o risco da nova igreja, aquela que deveria ser, juntamente com o colégio, definitiva. Tanto assim que em 1604 já se estava providenciando a obtenção de material para a construção dessa nova igreja que "ainda não havia sido iniciada", e que ele, Francisco Dias, ficou definitivamente no Brasil, onde morreu aos noventa anos de idade, em 1632, aqui no Rio de Janeiro. Só o benemérito jesuíta, Dr. Serafim Leite, no desenvolvimento da sua obra notável, poderá esclarecernos convenientemente essa importante questão ${ }^{2}$.

Torna-se ainda necessário observar que a composição da fachada dessa igreja baiana denota ter havido, da parte do arquiteto que a projetou - ou dos que o sucederam durante o andamento das obras - uma certa hesitação na escolha do partido definitivo. Hesitação resultante do desejo, aliás mal sucedido, de conciliar a solução tradicional de duas torres, com o 
aquela traça de São Roque que the era familiar. 0 que, ainda assim, não exclui a hipótese de esse mesmo arquiteto ter elaborado, mais tarde e já então convenientemente informado do novo partido de composição em voga na

Europa, um segundo risco - projeto que teria servido de base para a construção definitiva. traçado erudito em voga desde que Vignola e Giacomo della Porta, e depois Maderna, nas igrejas de Jesus e de Santa Susana, respectivamente, fixaram o novo padrão de frontispício sem torre, geralmente conhecido por "jesuítico" (fig. IIIa). Assim, por exemplo, (fig. IIIb) enquanto as volutas da empena desenvolvem-se livremente (1), o frontão que remata o corpo central ficou reduzido a proporções exíguas (2) e as torres, vistas de frente, mal cabem na fachada (3), parecendo mais sineiras que propriamente torres, a ponto de o conjunto reproduzir, feita abstração dos pormenores e da escala monumental, a silhueta das pequenas capelas de duas sineiras, comuns tanto na metrópole como na colônia (fig. IIIc).

Muito curioso é também o confronto desse frontispício com o da igreja de Santo Alexandre, em Belém do Pará - as duas igrejas jesuíticas do Brasil cujas torres foram concluídas, de uma só vez, pelos próprios padres da Companhia. Aqui, porém, as volutas descomunais transbordam por sobre as torres atarracadas (fig. IIId) e, embora ambas as igrejas respeitem, em suas linhas gerais, o mesmo partido de composição compacta, aquilo que na do Salvador é medida, apuro e distinção, no Pará se traduz de uma forma tosca e meio bárbara, com certos elementos tão fora de escala que chegam mesmo a parecer brutais. $\mathrm{O}$ que, entretanto, não deixa de ter a sua beleza, assim como um autêntico fruto da terra, em contraste com a arquitetura mais recente da cidade, tanto religiosa como civil, arquitetura já da segunda metade de setecentos, toda ela requintada e cem por cento reinol.

Aliás, o que tem confundido, neste particular, os nossos críticos, a ponto de passarem, até hoje, despercebidos os poucos vestígios ainda existentes de monumentos e retábulos dos últimos decênios do primeiro século e começo do de seiscentos, é que as obras desse período apresentam geralmente proporções elegantes, mais "sobre o alto" (fig. Ili), e um apuro maior no desenho e acabamento, o que não lhes dá aparência de coisa muito velha. Poderão mesmo parecer, à primeira vista, obras relativamente recentes, em todo caso, mais "modernas" que outras reconhecidamente da segunda metade de seiscentos ou de começo do século XVIII, cujas proporções "sobre o quadrado" - consequentemente mais pesadas (fig. IIj) - e o aspecto tosco da ornamentação, impressionam como coisa "primitiva".

Assim, embora não se possa fixar, a rigor, um critério cronológico uniforme para a apreciação das nossas obras de arte jesuíticas, pode-se contudo esclarecer, desde logo, que esse ar excessivamente primitivo é, muitas vezes, indício de trabalho menos antigo - já do segundo período.

Anotemos ainda, antes de concluir, mais algumas das particularidades das igrejas jesuíticas aqui documentadas.

Quando a cobertura das torres era feita com tijolo - como nas igrejas 
do Espírito Santo e do Estado do Rio: Reritiba, Reis Magos, Santiago, São Pedro d'Aldeia, Campos, Itaguaí etc. - ficava sempre à mostra, pelo lado de fora, o acabamento natural do extradorso caiado, em forma de "meia laranja", indicando-se assim, sem rebuços, a boa influência da técnica moçárabe (fig. IIIe). Quando era feita com pedra e cal, como na igreja carioca do Castelo, prevalecia geralmente o acabamento em forma de pirâmide (fig. IIIf). Na igreja de São Paulo, conservou-se esse mesmo acabamento agudo, mas com telhado, por se tratar ali de uma estrutura de pedra e barro a exigir proteção adequada (fig. IIIg). Na curiosa torre sineira, tão atarracada, da capelinha do Município de São Roque, a cobertura é também de telha e no mesmo estilo, porque assenta sobre esteios de madeira, independentes do corpo inferior da torre, que é de pedra (fig. IIIh). Solução esta transferida depois, pelos próprios paulistas, para as capelas e igrejas matrizes de barro e madeira, de Minas Gerais.

Só mais adiante, já em pleno século XVIII, aparece, nesses coroamentos de torre, o perfil bulboso, aliás, como simples corolário barroco e não por um artifício de inspiração oriental, como tantos supõem (fig. IIIi).

Apesar dos exemplos importantes de Salvador, de Belém do Pará, de São Luís do Maranhão, e mais alguns outros, de igrejas já da primeira metade do século XVIII, o frontão reto (fig. IIIj) é o que melhor caracteriza as igrejas jesuíticas brasileiras, pois que elas não alcançaram o pleno desenvolvimento do barroco em meados e na segunda metade de setecentos. O tipo de transição entre essa forma regular e a forma livre barroca é o que apresenta volutas rampantes sobrepostas ao frontão clássico primitivo, mantendo-se assim, apesar da nova silhueta, a rigidez da empena retilínea, como nos mostra a igreja de São Pedro d'Aldeia (fig. IIIk).

No caso do Seminário de Belém de Cachoeira, o frontão caprichoso e bem lançado data já da segunda metade do século XVIII (fig. IIIl). O consolo existente em frente ao óculo do tímpano, e que teria servido de suporte a alguma antiga imagem, é o único vestígio do frontão reto primitivo, contemporâneo da porta e dos demais elementos seiscentistas ainda existentes. Enquanto em São Paulo, o frontão mais baixo do que a empena (fig. 28) era mesmo seiscentista, correspondendo ao ponto do telhado primitivo, cujo alteamento fora feito anteriormente a 1810, data em que já aparece alteado, na planta da imperial cidade de São Paulo, levantada pelo Capitão de Engenheiros Rufino José Felizardo da Costa.

Quanto às portadas, tanto se encontram frontispícios de uma porta só, como conjuntos formados por cinco vãos, partido que, depois da construção da igreja nova do Salvador, repetiu-se no Recife, em Belém do Pará e em numerosas igrejas de menor interesse, já de meados do século XVIII, inclusive na grande igreja inacabada do Castelo, com portais de mármore de Lioz, enquanto a igreja velha tinha apenas a porta central, com uma cercadura de 


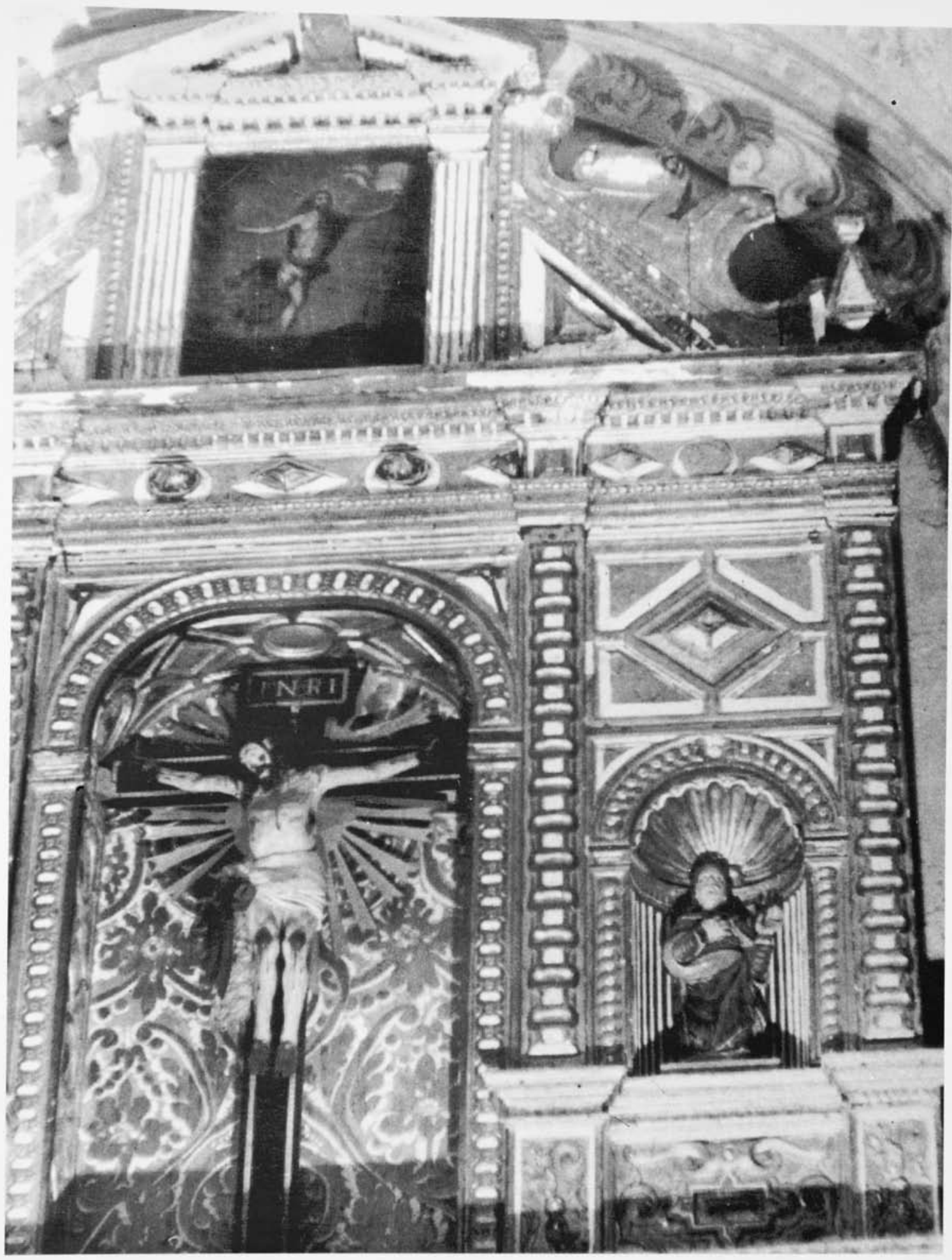


Na página anterior, Fig. 10: Igreja do antigo Colégio da Bahia. Pormenor do retábulo que teria pertencido à capela-mor da igreja construída por Mem de Sá para os padres da Companhia. granito do país, de risco severo, ainda com frontão inteiro, de fins do século XVI. Também, nas igrejas menos pretensiosas do século seguinte, era comum a porta única, como na do antigo Colégio de Vitória, já com frontão partido, de acordo com o estilo da época, e nas demais igrejas jesuíticas do Rio de Janeiro e do Espírito Santo, ou então, numa técnica diferente, o modesto mas importante portal de madeira, com inscrição de 1622, da capela paulista de São Miguel, que ainda conserva a porta e a ferragem primitivas (fig. 17).

Convém observar, entretanto, que no desenho de todas essas portadas, com exceção talvez das de Santo Alexandre, prevalece a linha elegante e o pormenor apurado e que são muitas vezes delicadamente ornamentadas, como ocorre com as da igreja do Espírito Santo, no Recife (fig. 31), prejudicadas pelas portas de um estilo muito mais moderno, que já não condiz com a da cantaria de 1689. Decoração classicista que vamos encontrar em outras portadas jesuíticas, como, por exemplo, na bela cercadura de pedra do chamado Engenho Retiro, em Sergipe (fig. 31), ou ainda, aberta na madeira, com boa técnica e muito gosto, no portal da capelinha do Município de São Roque, em São Paulo, conservado em bom estado porque a capela era alpendrada (fig. 31). E tudo sempre em completo desacordo com a ideia errônea, mas tão generalizada, dos que pensam descobrir no aspecto mais pesado, no menor apuro e na ausência de ornamentação dos elementos arquitetônicos, a característica das obras de procedência jesuítica.

Importa, ainda, chamarmos atenção aqui para a interessante casa de residência dos padres no antigo engenho hoje denominado do Colégio, em Sergipe, que, pelas particularidades do seu estilo, é exemplar talvez único no país e, por esse motivo, está sendo estudada pela Seção Técnica do SPHAN, juntamente com a arquitetura civil (fig. 32). Estudo em que se analisa também a parte que coube, de fato, aos jesuítas, não propriamente na criação de uma nova técnica ou de soluções novas, mas na divulgação pelo interior do país, através dos seus colégios e aldeias, das soluções e das técnicas de uso corrente, apreendidas primeiro por eles do próprio elemento civil e ajustadas, depois, às necessidades particulares do seu programa, também em grande parte residencial.

Da mesma forma no que se refere a obras de natureza especial, como, por exemplo, a tão conhecida ponte-represa jesuítica no rio Guandu, em Santa Cruz, obras que, conquanto de iniciativa de certo modo "privada", foram, em razão do seu caráter utilitário, incluídas, como as demais pontes, aquedutos, galerias subterrâneas e chafarizes, num estudo à parte sobre obras públicas.

Vê-se pelo exposto que a arquitetura da Companhia, no Brasil, foi quase sempre inimiga dos derramamentos plásticos, despretensiosa, muitas 
vezes pobre, obedecendo, em suas linhas gerais, a uns tantos padrões uniformes. E se devêssemos resumir, numa só palavra, qual o traço marcante da arquitetura dos padres, diríamos que foi a sobriedade. Sobriedade presente também nos retábulos, mesmo os mais ricos. Sobriedade que se impõe, apesar do gongorismo da obra de talha de um determinado período, como nos púlpitos esplêndidos de Santo Alexandre. Sobriedade que ainda souberam manter no mais pretensioso de seus templos, a atual Sé da Bahia.

Passemos a apreciar, agora, a composição das igrejas jesuíticas do ponto de vista de seus elementos de arquitetura interior, principalmente no que diz respeito às obras de talha. Antes, porém, vejamos qual foi, em suas linhas gerais, a evolução do "risco" dos nossos retábulos, considerados independentemente das características próprias ou das preferências de cada comunidade religiosa, de cada irmandade ou de cada região.

Do primeiro estilo - o mais caracterizadamente jesuítico - até ao estilo mineiro da última fase, cuja obra-prima é a capela-mor da igreja de São Francisco de Assis, em Ouro Preto, estilo apenas alcançado pelos padres, as transformações sucessivas repetem, curiosamente e na mesma cadência, as várias etapas que percorreu o conjunto da arte europeia, na sua evolução da Idade Clássica à Renascença, através dos estilos medievais românico e gótico.

Assim, por exemplo, encontramos de início os belíssimos retábulos, tão bem compostos e eruditos, de fins do século XVI e primeiros decênios do século XVI, - a nossa "antiguidade" - retábulos que, conquanto ainda não sejam propriamente barrocos, também já não são mais exclusivamente obras do Renascimento. Pertencem à fase de transição em que os traços renascentistas e barrocos se justapõem e confundem. Pós-renascentistas ou protobarrocas, as obras dessa fase formam, entre os dois movimentos, uma espécie de "terra de ninguém". Pareceu-nos assim mais razoável, uma vez que a nossa arte colonial se enquadra dentro do ciclo barroco, considerarmos aqui tais obras como um começo desse ciclo, de preferência a classificálas como sobras ou resto de "renascença" (fig. IVa).

Depois do período inseguro, confuso e sombrio de lutas e invasões, vamos encontrar retábulos de um estilo completamente diferente dos primeiros, tanto na composição como na talha, e cujo partido de colunas torsas repetidas em planos reentrantes, com arquivoltas concêntricas, recorda muito de perto o das velhas portadas românicas, apresentando ambos, apesar da distância no tempo, a mesma mistura de tradição romana e de inspiração oriental. O que talvez se explique por serem esses retábulos mais comumente franciscanos - ordem que tem a seu cargo, desde longa data, a guarda do Santo Sepulcro.

Esse estilo, rico, severo e bonito, generalizou-se e, muito embora tenha perdurado até começos de setecentos, pode ser considerado o estilo 
seiscentista por excelência. Inclusive da Companhia de Jesus (fig. IVb).

Já para fins do século, porém, a trama regular que serve de fundo à opulenta ornamentação desses retábulos vai perdendo a sua concisão. As colunas se afastam para dar lugar às imagens, os arcos se abrem para receber o dossel sobre o trono; multiplicam-se os anjos, as volutas, os florões e as linhas mestras do desenho quase que se perdem, levadas pelo ímpeto e pela profusão de formas que irrompem, uma a uma, por toda parte (fig. IVc).

Ainda se conservam magníficos exemplares desse estilo, característico principalmente, da primeira metade do século XVIII.

Estilo também das grandes matrizes mineiras, e já tratado pela nova geração modernista da segunda metade daquele século, isto é, dos artistas que ergueram as igrejas de irmandades - como "antigo" e de "gosto gótico", conforme se vê, entre tantos outros documentos, na importante memória feita pelo $2^{\circ}$ vereador da Câmara de Mariana, em 1790, e que, transcrita na sempre citada biografia de Antônio Francisco Lisboa, de Rodrigo Bretas, passou muito tempo despercebida, tendo mesmo confundido certos críticos.

Esse novo etilo, "moderno", como então se dizia, data da segunda metade do século XVIII, e já não é quase mais, portanto, contemporâneo dos jesuítas. Corresponde a um verdadeiro renascimento, com a volta às composições mais claras e arrumadas da primeira época. $\mathrm{O}$ lindo desenho e a primorosa talha, aliviados de tanto ornato e de tanto ouro, desenvolvem-se desafogadamente, elegantes, cheios de invenção e de graça, levando o capricho e a sutileza dos "achados" muitas vezes até ao requinte, senão mesmo ao enfado (fig. IVd).

Do exposto, resulta que se pode razoavelmente falar de um "classicismo barroco", de um "romanicismo" e de um "goticismo" barrocos e, finalmente, de um "renascentismo barroco", sem pretender significar com essas expressões semelhança formal, - embora ela de fato exista, algumas vezes, nas linhas gerais ou num ou noutro pormenor, - senão uma concordância no processo evolutivo muito curiosa e, principalmente, muito útil para permitir às pessoas menos familiarizadas com o assunto apreenderem mais facilmente o que há de fundamental nessa evolução.

Seja como for - não se considerando o estilo neoclássico que sucedeu, na primeira metade do século XIX, à dinastia barroca, os subestilos de transição, as variantes de caráter local ou a "maneira" própria de alguns artistas mais dotados -, podem-se distribuir as manifestações de arte barroca no Brasil, no que se refere à talha e composição dos retábulos, por quatro períodos essenciais, correspondendo a cada um deles um estilo determinado:

$1^{\circ}$. fins do século XVI e primeira metade do século XVII;

$2^{\circ}$. meados e segunda metade do século XVII e princípios do século XVIII; 


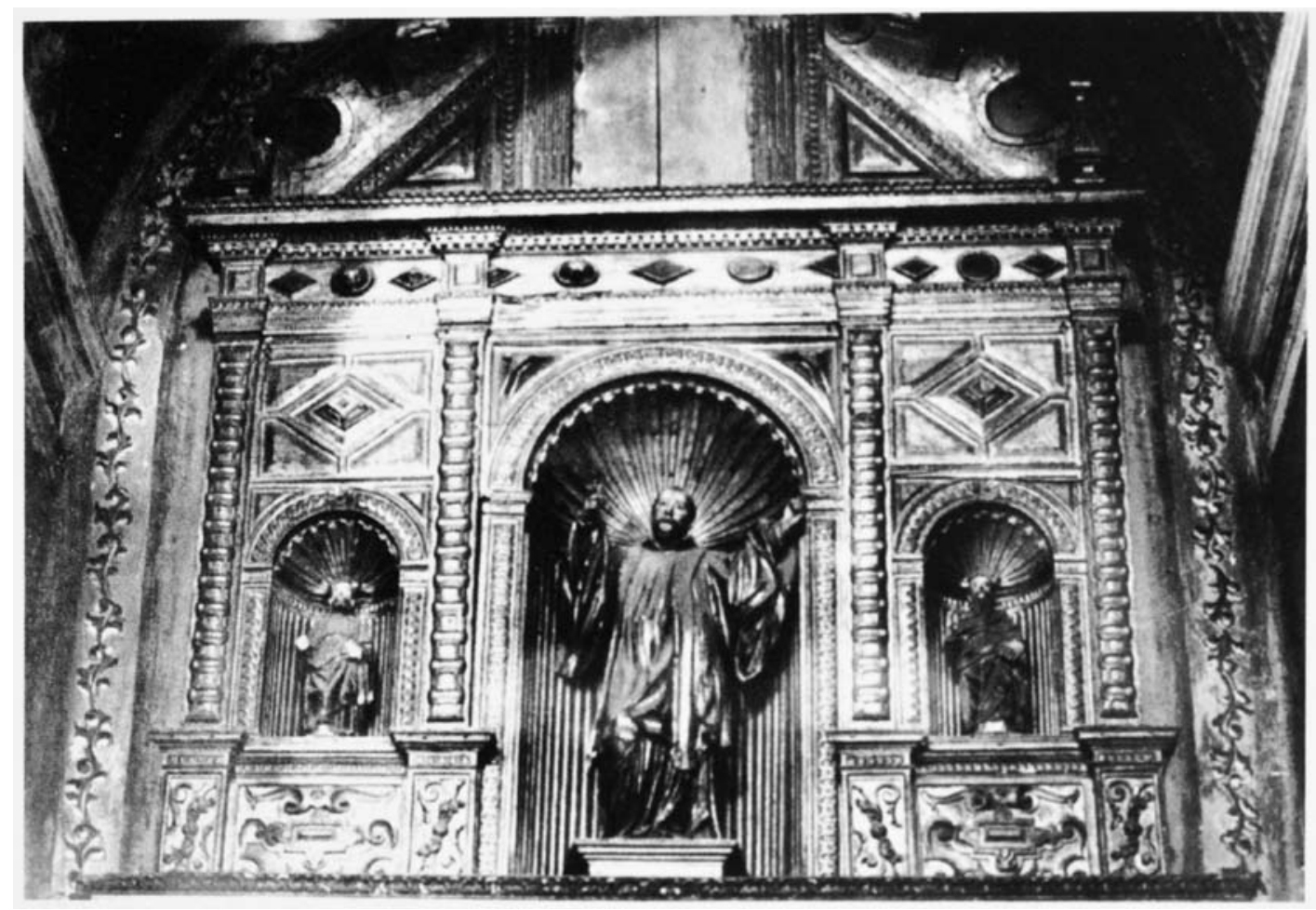

Fig. 11: Retábulo que teria pertencido à igreja construída por Mem de Sá para os jesuítas e corpo inferior do retábulo da capela dos Santos Mártires, ambos na igreja do antigo Colégio da Bahia.

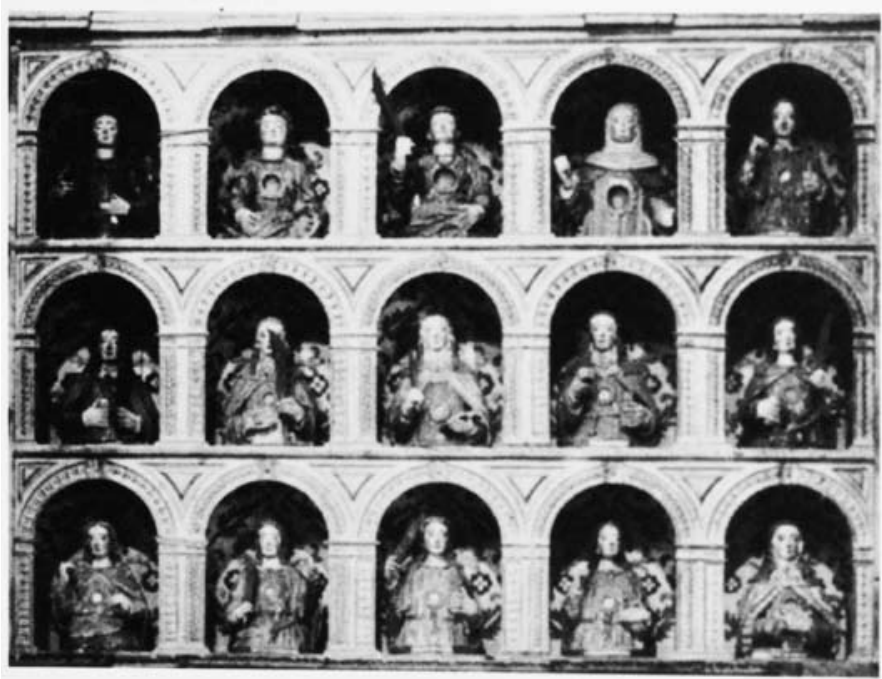


Fig. 12: Frontispício, retábulo e terca decorada da capela da antiga aldeia de Carapicuíba, no Estado de São Paulo.
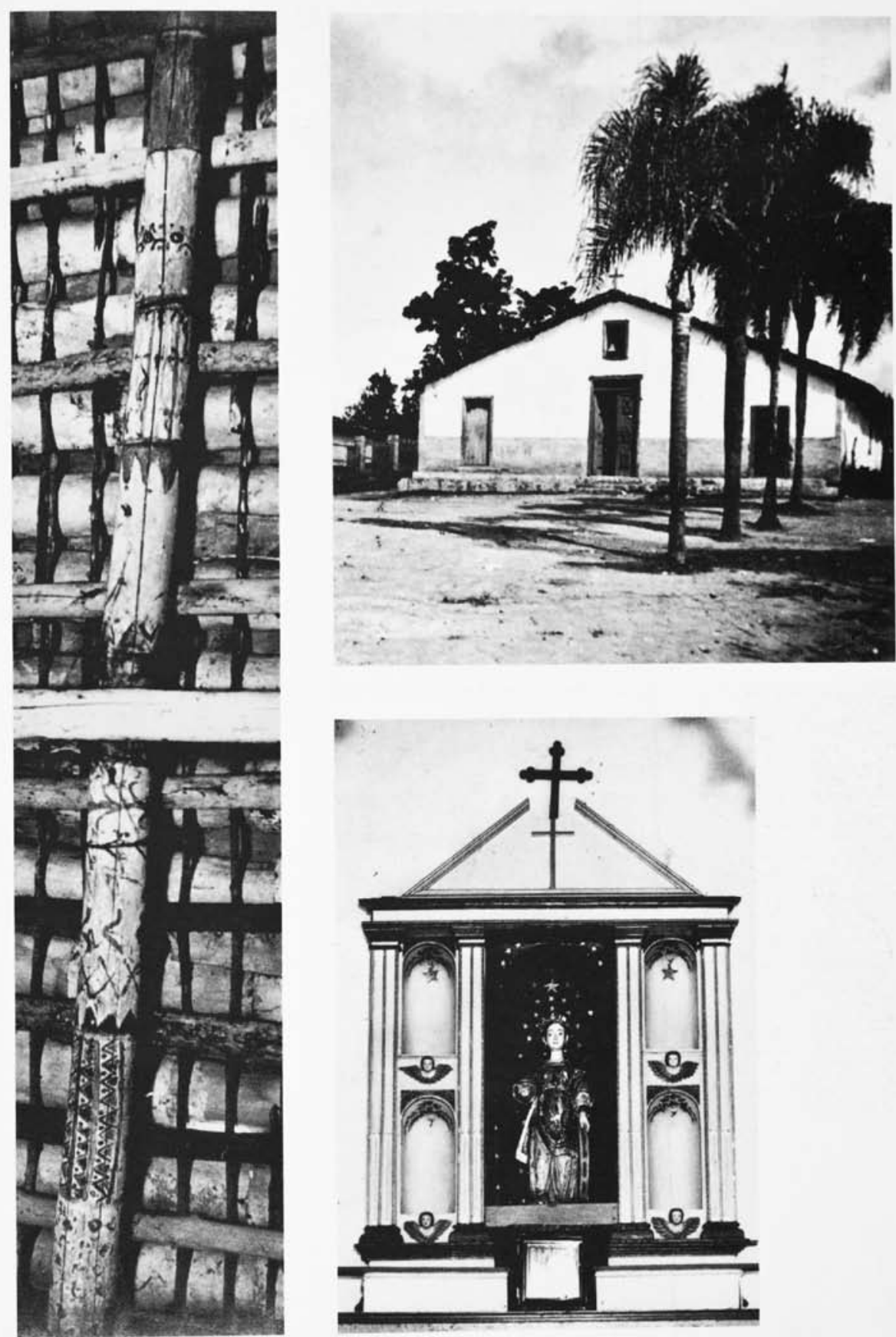
$3^{\circ}$. primeira metade e meados do século XVIII;

$4^{\circ}$. segunda metade do século XVIII e princípios do século XIX.

Delimitado desta forma o terreno, passemos então ao exame das obras que pertencem às igrejas da Companhia.

Graças às pesquisas efetuadas pelo Serviço do Patrimônio Histórico e Artístico Nacional, foram identificados e devidamente classificados vários retábulos jesuíticos do primeiro período, figurando aqui, pela primeira vez, a respectiva documentação fotográfica.

$\mathrm{O}$ valor dessas peças como raridade e o seu interesse histórico e artístico são de tal ordem que é muito de se estranhar - acessíveis como se encontram - não tivessem elas ainda despertado a atenção dos nossos entendidos em arte colonial.

A relação dos retábulos é a seguinte: $1^{\circ}$ ) os que pertencem aos três altares da igreja do antigo Colégio desta cidade, hoje guardados na igreja da Misericórdia, salvos à última hora de total destruição, quando do desmonte do morro do Castelo, graças à oportuna intervenção do então provedor da Santa Casa, Dr. Miguel Joaquim Ribeiro de Carvalho, e do engenheiro da mesma casa, Dr. Miguel Calmon Du Pin e Almeida; acham-se em perfeito estado de conservação, muito embora no retábulo do altar-mor faltem o arco central e o corpo inferior correspondente ao riquíssimo sacrário e tenham sido discretamente repassados, todos eles, com retoques de pintura e verniz (figs. 3 e 4); $2^{\circ}$ ) o do altar-mor da igreja de São Lourenço dos Índios, em Niterói, infelizmente dourado e pintado de novo (fig. 6), mas ainda com a imagem do padroeiro, conservando-se também, procedentes dessa mesma igreja, conquanto guardados na matriz de igual invocação, oito belíssimos castiçais de prata, quatro deles da primitiva banqueta e cinzelados no mesmo estilo do retábulo (fig. 7), dois grandes tocheiros de madeira e uma valiosa cadeira de braços, com assento e encosto de sola lavrada - material carinhosa e incansavelmente defendido pelo "amigo de São Lourenço", Sr. Araribóia Cardoso, velho e apaixonado pesquisador da história local, há pouco falecido; $3^{\circ}$ ) quatro colunas e um sacrário do antigo Colégio de São Vicente, colunas posteriormente dispostas de forma a receber o atual dossel (fig. 8); $4^{\circ}$ ) os dos altares colaterais da igreja da Graça, do antigo Colégio de Olinda, que, apesar de um tanto desfigurados, ainda conservam intactos os elementos identificadores essenciais (fig. 5); $5^{\circ}$ ) dois retábulos - os das capelas dos Santos Mártires e das Virgens Mártires - na igreja do antigo Colégio da Bahia e de que trataremos depois, juntamente com a arquitetura interior desse importante monumento (figs. 9 e 10).

Todos esses retábulos apresentam as mesmas características: o tratamento especial dos capitéis coríntios, um tanto repolhudos (fig. Va); os fustes estriados de preferência diagonalmente, vendo-se no terço inferior, ornamenta- 
ção ainda ao gosto dos grotteschi da primeira Renascença (fig. Vb), ou, então, cartelas de bordos recortados em tiras que se entrelaçam e enroscam (fig. Vc) (motivo muito em voga por toda parte naquela época, inclusive nos desenhos de arte gráfica, como, por exemplo, o da capa da Gramática de Anchieta, editada em 1595), (fig. Vd); as pinturas enquadradas acima do entablamento, entre mainéis recamados de folhas de acanto ou de escamas (fig. V e \& f); as volutas de desenho caprichoso (fig. Vg); os pináculos marcando a prumada dos fustes (fig. Vh); os dentículos, os óvulos, as caneluras. E tudo, neles, é tratado exatamente no mesmo estilo rico, elegante e bem articulado, dos altares portugueses e espanhóis de fins do século XVI e começo de seiscentos, quando a experiência "plateresca", banida das fachadas, refugiou-se nas obras internas de talha, conforme se poderá facilmente verificar confrontando-os com os retábulos reconhecidamente filipinos, reproduzidos na obra de Alfredo Guimarães, Mobiliário artístico português, volume II.

O desenho dessas peças, afinal uma transcrição em madeira do desenho das portadas quinhentistas espanholas "lavradas como prata", baseia ainda, como estas, a sua composição na dos altares sepulcrais do quattrocento italiano, dos quais se contam, entre os mais conhecidos, os de Andrea Sansovino, artista que viveu em Portugal no último decênio do século $\mathrm{XV}$, a serviço de D. João II, para quem teria executado, segundo Vasari, entre muitos outros trabalhos de que se não conhecem vestígios, também um altar.

Quanto à procedência daqueles nossos retábulos, parece mais verossímil - os da igreja do Castelo, pelo menos - que, muito embora fabricados com madeira do país, tivessem vindos já prontos da metrópole, pois a análise dessa madeira, feita pelo Instituto Tecnológico de São Paulo, revelou tratar-se de "freijó" ou louro amarelo, espécie vegetal abundante na bacia amazônica e, segundo nos consta, desconhecida aqui. Teria sido, na verdade, inadmissível que, dispondo à mão de material de primeira ordem, fossem os padres do Colégio do Rio de Janeiro recorrer à importação de madeiras de tão longe. Ao passo que a hipótese de os altares terem sido feitos em Portugal fica fortalecida quando se considera que esse comércio era feito, então, diretamente do extremo norte do país com a metrópole, utilizando-se os reinóis dessa madeira inclusive na execução de obras de marcenaria e de talha destinadas aos trópicos, pois que a experiência já desaconselhara o emprego das espécies europeias para esse fim.

Se essas peças, de estilo apurado e de aspecto tão scholar - verdadeiramente jesuíticas - parecem com efeito proceder de Portugal, outro tanto não se poderá dizer das interessantíssimas versões populares seiscentistas desses mesmos retábulos, agora identificadas pelo SPHAN em São Paulo, Estado que tem fama de ser pobre em arte colonial, mas que ainda conserva despreocupadamente - como joias de família, sem valor - os dois "únicos" 
exemplares do gênero existentes no país. São eles os dois retábulos das capelas já referidas de N. Sra. da Conceição, de Voturuna (fig. 13) e de Santo Antônio, esta no Município de São Roque (fig. 16), inventariadas ambas pelo Sr. Mario de Andrade para o SPHAN, desde 1937, mas que só recentemente puderam ser examinadas mais de perto pela Seção Técnica deste Serviço, até então empenhada no estudo de material de outras regiões.

Na composição do de Voturuna, foi simplesmente aproveitado o desenho dos frontões de coroamento dos retábulos originais, transferindo-se engenhosamente o nicho, do corpo inferior do retábulo, corpo este no caso inexistente, para a parte central do frontão (fig. Vi). Os pormenores de perfilatura e de ornamentação também reproduzem, de memória, os ornatos e perfis dos modelos portugueses, vendo-se, porém, entre as frutas amarradas por uma faixa - motivo europeu então na moda e já encontrado no frontão do retábulo da igreja de São Lourenço dos Índios e que encontraremos ainda, mais tarde, nos vestígios da cantaria da igreja de Santo Ângelo das Missões, no Rio Grande do Sul, - dois minúsculos abacaxis (fig. 14).

$\mathrm{O}$ aspecto tosco e vigoroso desta peça, verdadeiramente singular, contrasta, apesar da identidade do estilo, com a "maneira" mais delicada e graciosa em que foi tratado o retábulo do altar-mor da capelinha do Município de São Roque, observando-se aqui, no desenvolvimento geral do risco, liberdades maiores, como essa de se ampliar desmedidamente o clássico painel central que, das proporções modestas usuais, passou a dominar toda a composição, desfigurando assim a ideia fundamental do desenho primitivo e conferindo ao conjunto uma aparência bem diferente da do seu modelo original (fig. $\mathrm{Vj}$ ).

Convém, no entanto, desde logo reconhecer que não são sempre as obras academicamente perfeitas, dentro dos cânones greco-romanos, as que, de fato, maior valor plástico possuem. As obras de sabor popular, desfigurando a seu modo as relações modulares dos padrões eruditos, criam, muitas vezes, relações plásticas novas e imprevistas, cheias de espontaneidade e de espírito de invenção, o que eventualmente as coloca em plano artisticamente superior ao das obras muito bem comportadas, dentro das regras do "estilo" e do bon ton, mas vazias de seiva criadora e de sentido plástico real. Não são, pois, estes retábulos paulistas simples cópias inábeis mas, muito pelo contrário, legítimas "recriações", podendo ser considerados, juntamente com os esplêndidos e originalíssimos tocheiros antropomorfos que lhes pertencem (fig. 15) e com a banca de comunhão de São Miguel (fig. 17b), como das mais antigas e autênticas expressões conhecidas de arte "brasileira", em contraposição à maior parte das obras luso-brasileiras dessa época, que se deveriam melhor dizer "portuguesas do Brasil".

Interessa ainda assinalarmos aqui a existência nessa capela de San- 
to Antônio de uma velha pintura reputada ininteligível em virtude do seu estado precário de conservação, mas que é, para nós, não obstante, documento do maior interesse, pois representa um altar cujas colunas, nichos, frontão e mais pormenores do retábulo são em tudo semelhantes aos daqueles altares mais antigos das igrejas do Castelo, de São Lourenço, de São Vicente ou da Graça (fig. Vk). Esse retábulo, provavelmente da primitiva capela existente no corpo da casa, teria então servido de modelo ao retábulo seiscentista atual e, possivelmente em mau estado de conservação, por ser talvez fabricado com madeira europeia, terá sido assim "retratado" para se guardar a lembrança dele na nova capela.

Também podem ser incluídos nesse primeiro grupo os dois pequenos e elegantes oratórios com acabamento de azul e ouro, existentes na sacristia da capela de São Miguel (fig. Vm), no mesmo Estado de São Paulo, e ainda, conquanto já do começo do século XVIII, o pequeno altar tão singelo da igreja de Carapicuíba (fig. 12).

Antes de passarmos a tratar dos retábulos do segundo período, indicaremos aqui dois exemplares desse novo grupo, onde ainda se observam vestígios do estilo anterior: o do altar-mor da igreja dos Reis Magos, no Espírito Santo (fig. 18), com curiosíssimo frontão de risco caprichoso e painel pintado, - reminiscência dos retábulos mais antigos, que o alteamento do quadro, originariamente colocado entre as colunas, ainda mais acentua (fig. Vo), e os dos altares da igreja do convento franciscano de Cabo Frio, os quais, a julgar-se pelo estilo, parecem ter sido trabalhados por algum artista familiarizado com o gosto e as preferências dos jesuítas, pois, além de muitos outros indícios, ainda aparecem, arrematando a composição da talha, de encontro ao forro apainelado da capela-mor, volutas no gênero das que, embora de uso generalizado nos fins do século XVI e na primeira metade do XVII, caracterizam melhor, no Brasil, os primeiros retábulos da Companhia (fig. Vn).

Entre os principais exemplares do novo estilo, devem-se destacar: o esplêndido retábulo da capela-mor da igreja do antigo Colégio de São Luís, no Maranhão (fig. 27), de composição clara e perfeita, apenas prejudicada pelo novo camarim, já do começo do século XIX; o elegante retábulo do altar-mor da igreja do Colégio de Campos (fig. 27), hoje completamente desfigurado, mas cujo traçado obedecia, em suas linhas gerais, a um desenho semelhante, e que as referências contidas no Santuário Mariano confirmam datar do século XVII; e, ainda, dois dos altares laterais da antiga igreja do Colégio de São Paulo (fig. 28), peças de grande valor que, infelizmente, os responsáveis pela sua guarda não souberam conservar. É muito interessante o confronto destes últimos retábulos com os dois pequenos dos altares laterais da muito citada capela paulista de Santo Antônio, no Município de São Roque, onde, 
como ali, se reproduz, em baixo-relevo, à maneira de friso, o motivo simbólico ornamental da videira, já então incorporado ao estilo barroco, mas geralmente tratado em alto-relevo ao redor dos fustes torcidos das colunas salomônicas (fig. 30 e VIa). Resultou dessa interpretação menos erudita do velho tema bizantino-românico, como que uma volta à técnica dos modelos originais, parecendo, assim, estes nossos dois pequenos retábulos seiscentistas, coisa fabricada no décimo século.

Outros importantes exemplos desse período vamos encontrar nos dois notáveis altares colaterais de Embu, mais antigos que o altarmor e que ainda ostentam a águia dos Filipes (fig. 29). Embora esse emblema, que também se encontra no púlpito da capelinha de São Roque, tenha sido algumas vezes empregado, posteriormente à Restauração, como simples motivo ornamental, é possível que, no caso em apreço, ainda corresponda, efetivamente, ao domínio espanhol - aos últimos anos, pois, pelo estilo, os retábulos não podem ser muito anteriores a 1640 .

Exemplar belíssimo de transição entre o estilo desse período e o seguinte é o que se pode admirar no que ainda resta da magnífica igreja de Geru, em Sergipe, - infelizmente dilapidada por um padre insensato -, obra mestiça e vigorosa que se enquadra no importante surto de arte ocorrido de fins do século XVIII a meados de setecentos, naquela região, e que constitui, a bem dizer, uma escola à parte (fig. 33). O partido do desenho dos fustes das colunas robustas procede ainda, de certo modo, conquanto diferente, daquele que vimos nos fustes decorados do grande retábulo baiano (fig. VIb), mas os goticismos a que já nos referimos, no começo deste estudo, repontam aqui de forma inequívoca por toda parte. Observem-se, por exemplo, as estranhas figuras que dividem em painéis, de acordo com as normas usuais do estilo, o espaço da empena compreendido entre o arco cruzeiro e o forro, ou seja, o frontispício da capela-mor (fig. VIc). Observem-se, também, o aparecimento dos culs-de-lampe entre as colunas para receberem as imagens, dantes colocadas dentro de nichos (fig. VId).

No antigo altar-mor da igreja do Colégio de São Paulo, o dossel rompendo a arquivolta, sobre o camarim - traço característico do etilo do terceiro período - parece um acréscimo ao risco primitivo (fig. VIe). Ao passo que o esplêndido retábulo do altar-mor de Embu já pode ser considerado obra da segunda fase desse novo período (figs. 24 a 36). O reticulado preciso, formado pela prumada dos mainéis e colunas e pela molduração horizontal das cornijas, das arquitraves e dos plintos (fig. VIf), permitiu que a talha cobrisse a parede de um extremo a outro, como um tapete, sem prejuízo de uma boa "amarração", como dizemos na gíria profissional.

São também do terceiro período, além do altar do Santíssimo na 
Fig. IV
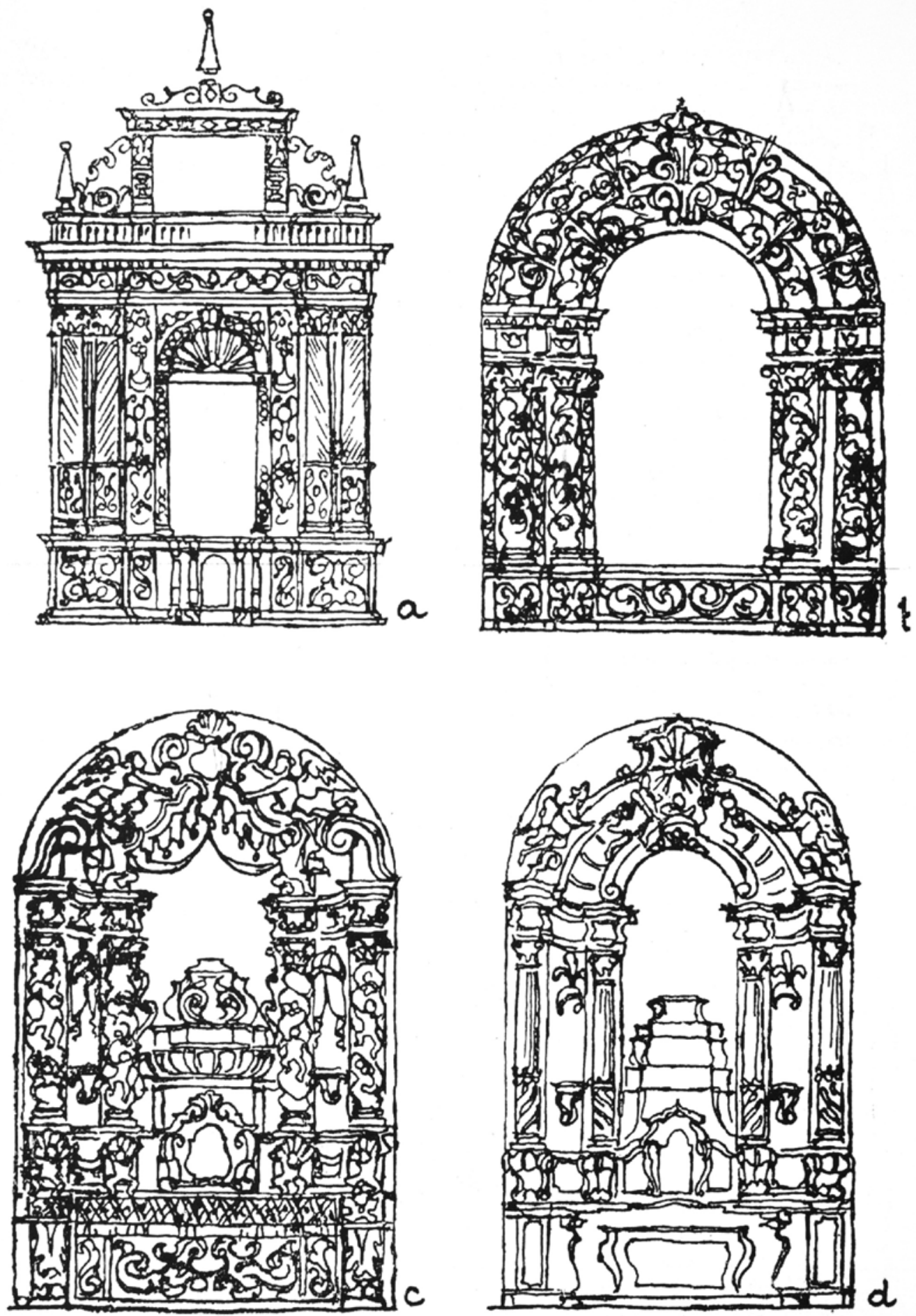
Fig. V
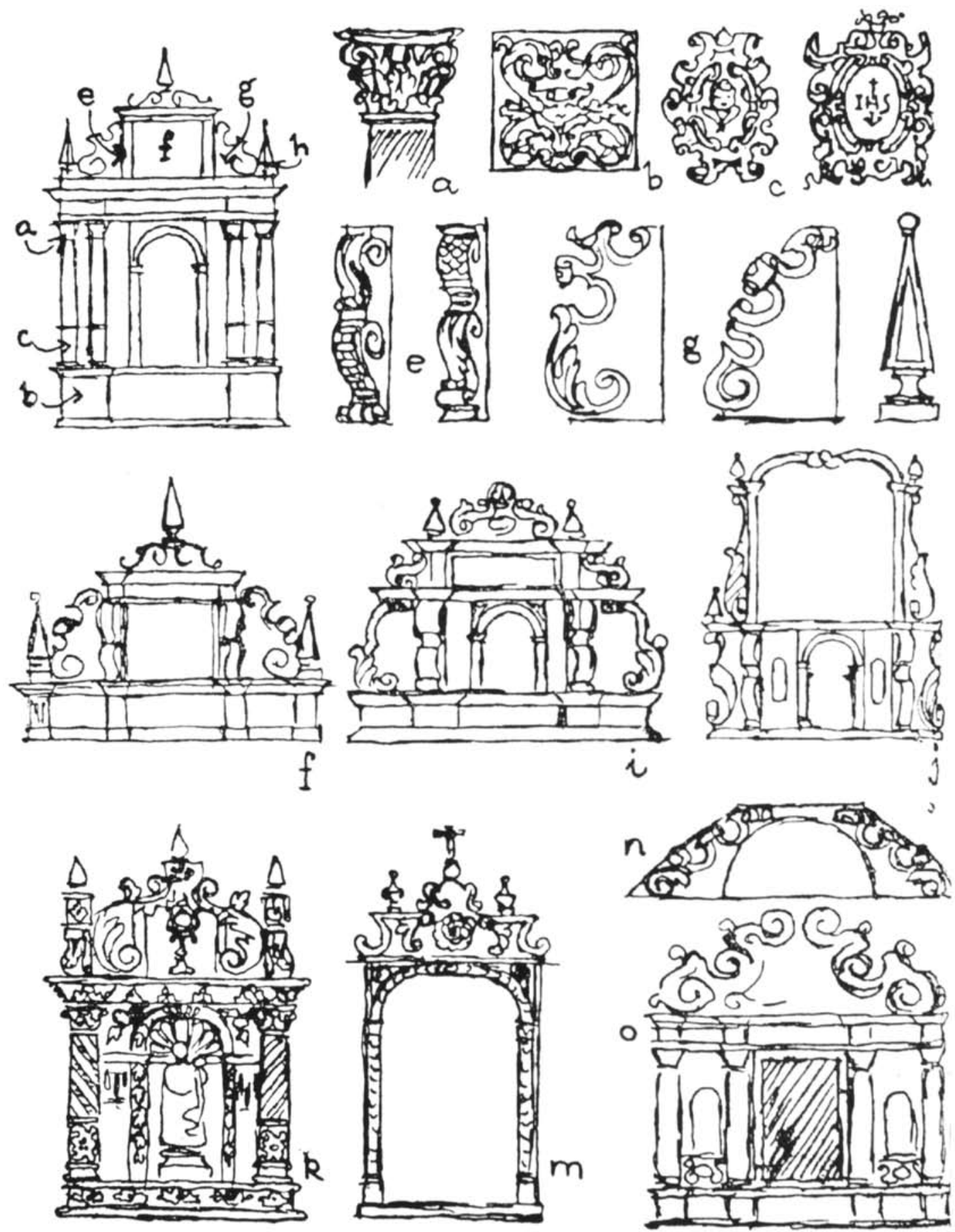
igreja da Bahia, de que trataremos depois, os numerosos altares e principalmente os púlpitos de Santo Alexandre, em Belém do Pará. Na composição e na talha de uns e de outros, observa-se o mesmo acento bárbaro referido anteriormente, quando aludimos à arquitetura dessa igreja. Mas, apesar da técnica grosseira, de que resultou, por vezes, um aspecto quase grotesco, apesar da falta de escala e de meia-tinta, o arrojo plástico e o sentido apaixonado da concepção dos púlpitos revelam um tal fervor, tamanho arrebatamento, que a sua análise não cabe dentro dos limites comedidos de uma crítica objetiva. A impetuosidade com que as formas irrompem pela parede acima tem mesmo qualquer coisa de telúrico, fazendo lembrar esculturas hindus talhadas sobre encosta de montanha (fig. 34).

Pode-se ajuizar melhor das características, sob certos aspectos antijesuíticos, dessas peças confrontando-as com os demais púlpitos jesuíticos, como, por exemplo, o de Embu, talvez o mais belo (fig. 1), ou com outros, mais modestos, simples caixas emolduradas sem sequer a "taça" de pedra ou madeira, ou mesmo com o elegantíssimo púlpito, munido de refletor de som, da igreja do Castelo, ou então, ainda dentro desse mesmo partido, mas em mármore, com os púlpitos de ar europeu, da Bahia.

Entretanto, é num dos altares laterais da igreja do antigo Colégio de Campos que a presença do nosso índio se manifesta, não apenas na maneira mais ou menos tosca de fazer ou de interpretar os modelos europeus usuais, como é o caso de Belém do Pará, ou mesmo, em parte, os de Voturuna, São Roque, Reis Magos e Geru, mas no próprio risco e na invenção do pormenor, senão mesmo até na técnica da talha (fig. 35). Essa obra brasileira, infelizmente mutilada em alguns trechos - faltam as duas volutas do frontão e, possivelmente, uma cornija de remate ao coroamento - data também do século XVIII, mas da segunda metade, e assim não terá sido, ao que supomos, contemporânea dos padres.

O bonito altar da sacristia da igreja baiana de Jaguaribe, valorizado em virtude do contraste com o estilo severo e mais antigo do arcaz e dos armários, e com o fundo branco da parede caiada, representa a transição entre esse terceiro período e o último - aquele que os jesuítas apenas alcançaram e cujos exemplares mais típicos são os dois retábulos das capelas de Santo Inácio e de São Francisco Xavier, na igreja do antigo Colégio do Salvador (fig. 37). Antes, porém, de considerá-los, tratemos dos demais altares dessa igreja que, por ter sido a "catedral" dos jesuítas na Província do Brasil, merece um mais detido exame.

Importa primeiramente apurar se teriam sido aproveitados na igreja seiscentista atual alguns dos retábulos dos três altares admirados, em 1583, pelo padre Fernão Cardim. 
O exame das características de estilo, próprias a cada um dos retábulos das dezesseis capelas dessa igreja, mostra muito claramente que os dois mais próximos da entrada (ambos de puríssimo desenho e de composição semelhante, senão mesmo, sob certos aspectos, mais renascentistas que a dos primeiros altares aqui estudados) são os mais antigos e também que foram adaptados ao pé-direito altíssimo das capelas onde estão colocados (fig. 9), pois o estilo do corpo inferior dos retábulos (fig. 21 ) já não é o mesmo da parte superior mais antiga (fig. 10), e sim contemporâneo da talha das extensas nesgas existentes nas extremidades da parede de fundo da capela-mor, onde se veem os mesmos motivos e a mesma técnica (figs. 20 e VIg).

Ora, se não foram feitos especialmente para a atual igreja e se são mais antigos que todos os seus demais altares seiscentistas, de onde poderiam eles ter vindo senão mesmo da igreja primitiva?

Ocorre, ainda, outra curiosa circunstância em relação aos belíssimos painéis do corpo inferior desses retábulos, de tanto maior interesse quanto neles aparecem representados, pela primeira vez, cajus em substituição às clássicas peras, indício de terem sido trabalhados no país (fig. 21). É que, embora simulem painéis fixos, são, na verdade, de abrir, encobrindo dois preciosíssimos relicários, um dos Santos Mártires, outro das Virgens Mártires, com quinze nichos cada um e outras tantas imagens, meios corpos de barro cozido. Muito embora o estilo da parte interna, isto é, dos nichos, pareça, de certo modo, contemporâneo do estilo do corpo superior dos retábulos, é evidente que não fazia parte integrante dele, pois a divisão dos nichos fez-se arbitrariamente, sem se levar na devida conta a prumada das pilastras que decompõem aquele corpo em três partes distintas (fig. VIh).

Conta, de fato, o padre Cardim, a propósito do Colégio da Bahia, que, por determinação do visitador, se fez ali, em 1585, um relicário assim descrito:

É grande, tem dezesseis armários com suas portas de vidraça, e no meio um grande, para a imagem de Nossa Senhora de S. Lucas; os armários são todos forrados dentro de cetim carmesim, portas da banda de dentro são forradas de sedas de várias cores, damasco, veludo, cetim etc. A madeira é de pau de cheiro de Jacarandá, e outras madeiras de preço, de várias cores de tal obra que se avaliou, somente das mãos, em cem cruzados. Fê-lo um irmão da casa, insigne oficial. Está assentado na capela dos irmãos.

Por onde se vê que não se tratava, ainda, do atual relicário. Como, porém, no Colégio do Rio, foi colocado na capela doméstica dos padres, em fins do primeiro século ou, em todo caso, antes de 1609 - o Dr. Serafim 

Leite, S. J. infelizmente não precisou a data -, um "relicário de mármore branco, com elegantes embutidos pretos de jacarandá" e "doze estátuas de santos, tendo cada qual, incrustada no peito, uma caixinha de cristal com a respectiva relíquia", - imagens portanto semelhantes às que nos interessam -, é de presumir-se que, depois da visita de Cristóvão de Gouveia, também à Bahia outras relíquias tivessem chegado, já então com os meios corpos de terracota, resultando daí a necessidade de se fazerem novos relicários de maiores proporções. E é possível que os dois altares mais antigos da sacristia, cujo mármore se mostra inexplicavelmente tão gasto, abrigassem inicialmente, ainda talvez na igreja de Mem de Sá, os meios corpos com as suas relíquias, até que fossem, uns e outros, transferidos para a nova igreja onde tiveram cada qual o seu destino.

Quanto aos demais altares dessa igreja baiana, podem ser classificados, de acordo com as particularidades de estilo dos respectivos retábulos, na seguinte ordem cronológica: $1^{\circ}$ ) o altar-mor (fig. 20), sendo que a parte superior do sacrário - espécie de "sobrado" (fig. 19) - parece ter sido aproveitada de outro sacrário, pois tanto a sua cornija, friso e arquitrave, como o embasamento, tornejam ligeiramente, uma segunda vez, depois do tornejamento maior correspondente às colunas geminadas, indício de ter havido ali um fechamento semelhante ao da parte de baixo (fig. VIi); aliás, esse segundo corpo encobre um grande arco destinado evidentemente a enquadrar a cúpula do sacrário propriamente dito, pois ainda se veem, no tímpanos desse arco, por detrás do referido "sobrado", meio escondidas, as clássicas cabeças aladas de querubins (fig. 19 e VIg); $2^{\circ}$ ) os altares de São Francisco de Borja (fig. 25) e de São Pedro (fig. 25), observando-se que a ornamentação corrida dos painéis laterais do corpo inferior desses retábulos foi mutilada no intuito de se abrir lugar para os culs de lampe com imagem e dossel (fig VIj); $3^{\circ}$ ) o altar de São José (fig. 25), no qual embora ainda se mantenha o mesmo partido de composição em painéis e, de um modo geral, o mesmo desenho (fig. VIk), a talha já perdeu no corpo superior aquela fatura miúda e delicada, de modelado baixo, com aparências de coisa cinzelada, que se observa na talha dos retábulos mais antigos, adquirindo, pelo contrário, maior largueza e volume, já no estilo generoso mais do agrado dos franciscanos; também aqui a ornamentação dos painéis do corpo inferior foi arrancada, recebendo eles inovações grotescas, do mesmo gênero das que foram introduzidas no nicho, onde apenas se conservam, isolados, uns poucos elementos primitivos, como as cabeças de querubins, nos tímpanos, e as impostas da arquivolta (fig. VIm); acresce, ainda, que a pintura do painel central também é recente e de qualidade inferior; $4^{\circ}$ ) os quatro altares, de

Fig. 14: Pormenor do retábulo da capela de Voturuna.
N. Sra. das Dores, N. Sra. da Conceição, Santa Úrsula (fig. 26) e Santa Ana (fig. 26), de fins do século XVII ou começo de setecentos, vazados no estilo 


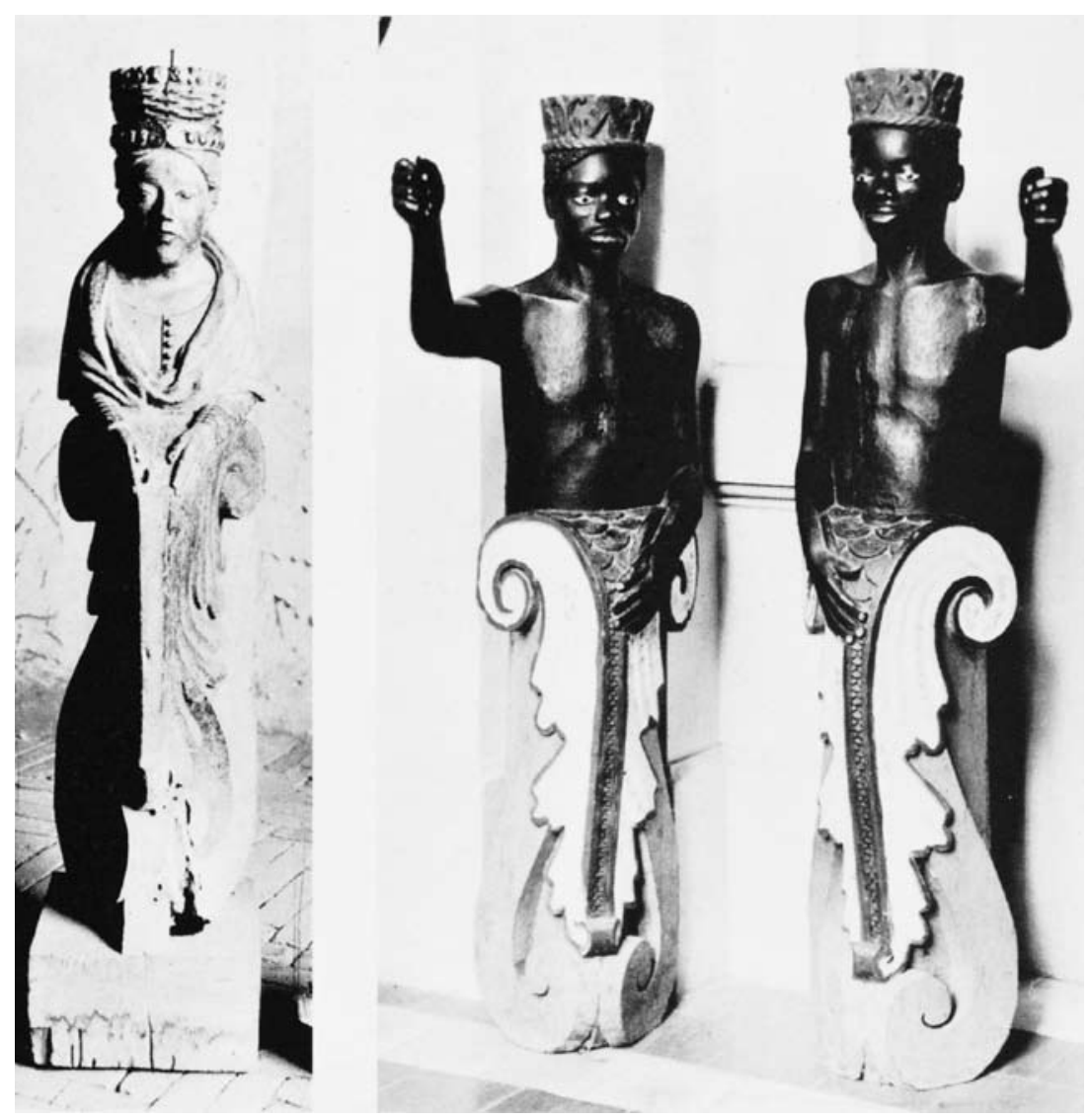

Fig. 15: Tocheiros antropomorfos, pertencentes, 0

primeiro

à capela de Voturuna e os dois últimos à de

São Roque. opulento e vigoroso característico da talha dessa época, que já não condiz com o estilo da igreja, e nos quais pode-se observar o abandono do partido de subdividir o retábulo horizontalmente em dois corpos, pelo de tratar-lhe a altura com uma única ordem de colunas (fig. VIl); $5^{\circ}$ ) o altar colateral do Santíssimo Sacramento, da primeira metade de setecentos, povoado de um número extraordinário de anjos, uns sustentando, sem grande esforço, o pesado dossel, outros, maiores, ocupando o lugar das colunas, sem contudo assumirem atitudes de cariátide; infelizmente o frontal, o sacrário e a grade de fechamento da capela destoam, pela vulgaridade do seu aspecto, do sentido triunfal que predomina na composição; $6^{\circ}$ ) finalmente, de meados do século XVIII - já de época próxima da expulsão - os dois retábulos, anteriormente citados, das capelas laterais dedicadas a Santo Inácio de Loiola e São Francisco Xavier (fig. 37), cujos entablamentos acompanham extravagantemente o arredondado dos fustes das colunas salomônicas (fig. VIn), onde já não mais se enroscam a vinha e os pelicanos, mas tão somente rosas, margaridas e palmas (fig. VIo); a silhueta ondulante das imagens, a doçura quase excessiva dos gestos e da expressão, a elegância sofisticada da com- 


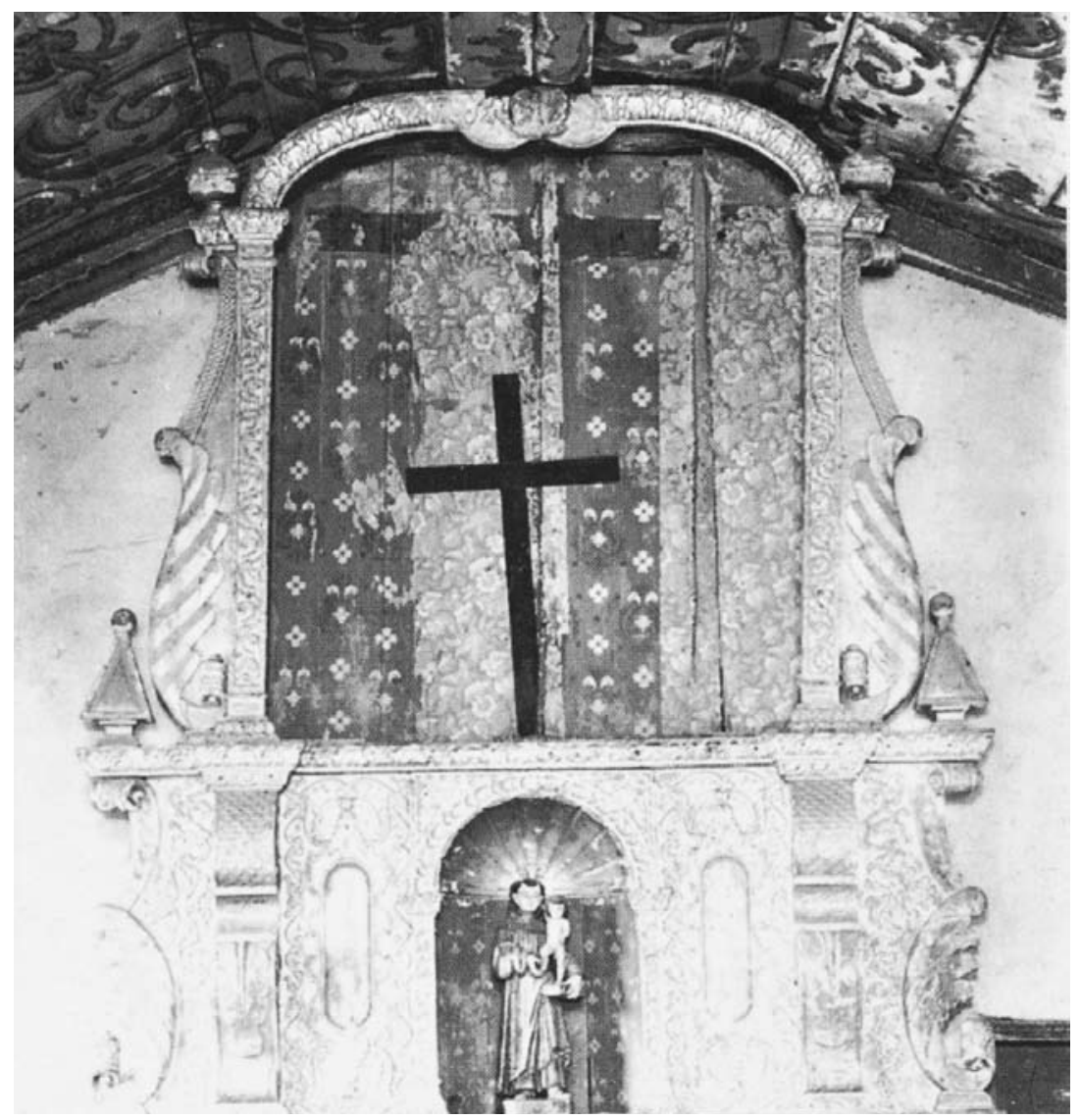

Fig. 16: Retábulo do altarmor da capela de Santo Antonio, no município de São Roque, em São Paulo. posição, no conjunto e nos pormenores, não possuem ainda o equilíbrio, a pureza de formas e a graça envolvente de tantas outras obras do mesmo gênero, existentes no país. Convém entretanto acentuarmos que o estilo destes retábulos, apesar de tão diferente do dos retábulos do primeiro período, tem com ele umas tantas afinidades, como, por exemplo, o modelado baixo da talha, certas delicadezas de técnica e o apuro bastante precioso e convencional do acabamento.

Apesar de toda essa prolixidade e riqueza, não se pode considerar a igreja do antigo Colégio da Bahia uma obra perfeitamente "realizada" do ponto de vista plástico. Concepção talvez pretensiosa demais, então, para o meio, nota-se, pela maneira por que foi tratado o seu corpo, internamente, um certo constrangimento, certa "pose", decorrente, ao que parece, da preocupação de manter atitude formalizada e solene.

Faltou-lhe, assim, um pouco daquela elegância fácil, daquele ar mais natural e ao mesmo tempo tão nobre e tão digno que caracteriza a belíssima sacristia (fig. 22), já descrita, em 1698, pelo Sieur Froger, 
Fig. 17: Frontispício, verga datada de 1622 e banca de comunhão da capela de São Miguel, em São Paulo.

Na outra página, Fig. 18: Frontispício, pormenor da torre e retábulo do altar-mor da igreja do antigo Colégio dos Reis Magos, atual Nova Almeida, no Espírito Santo.
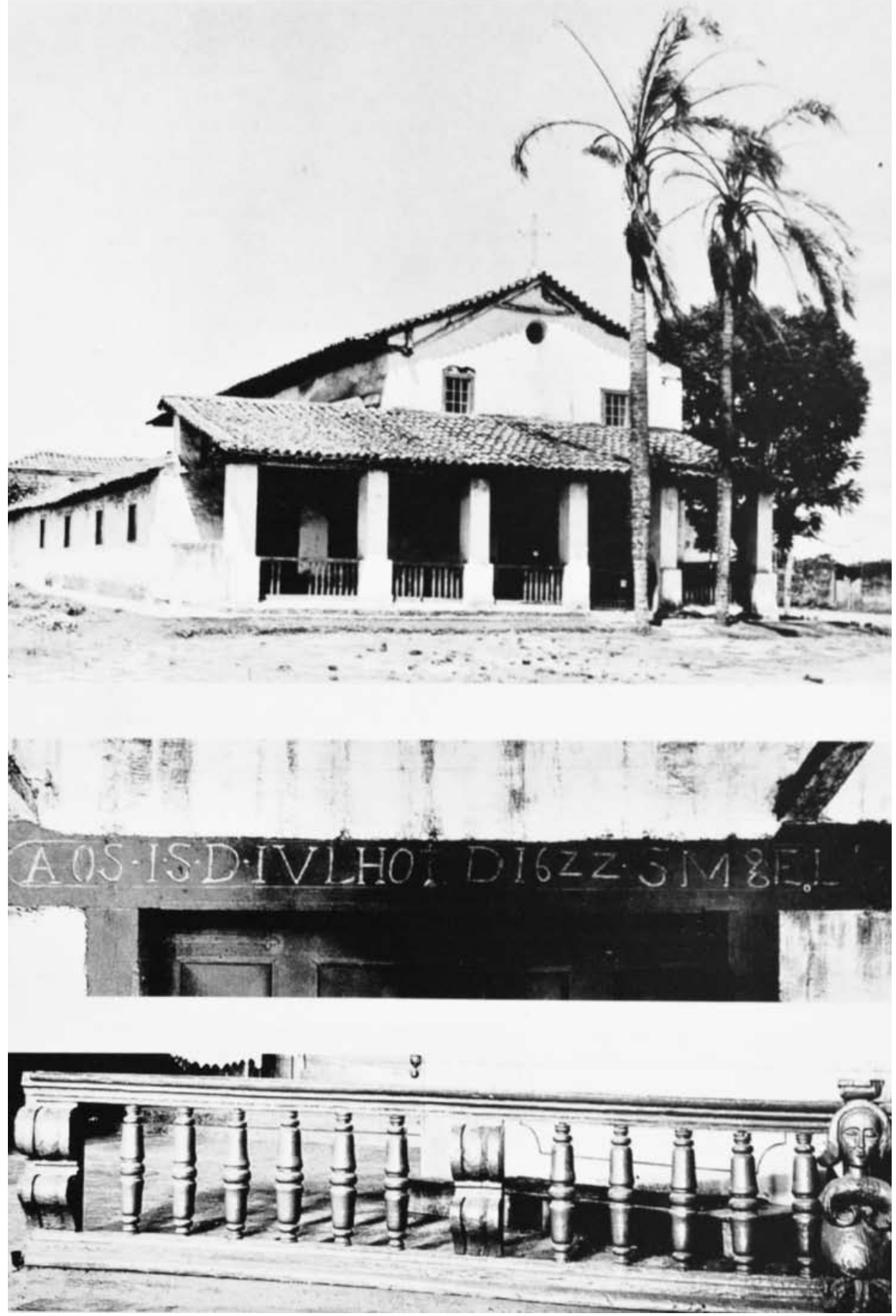

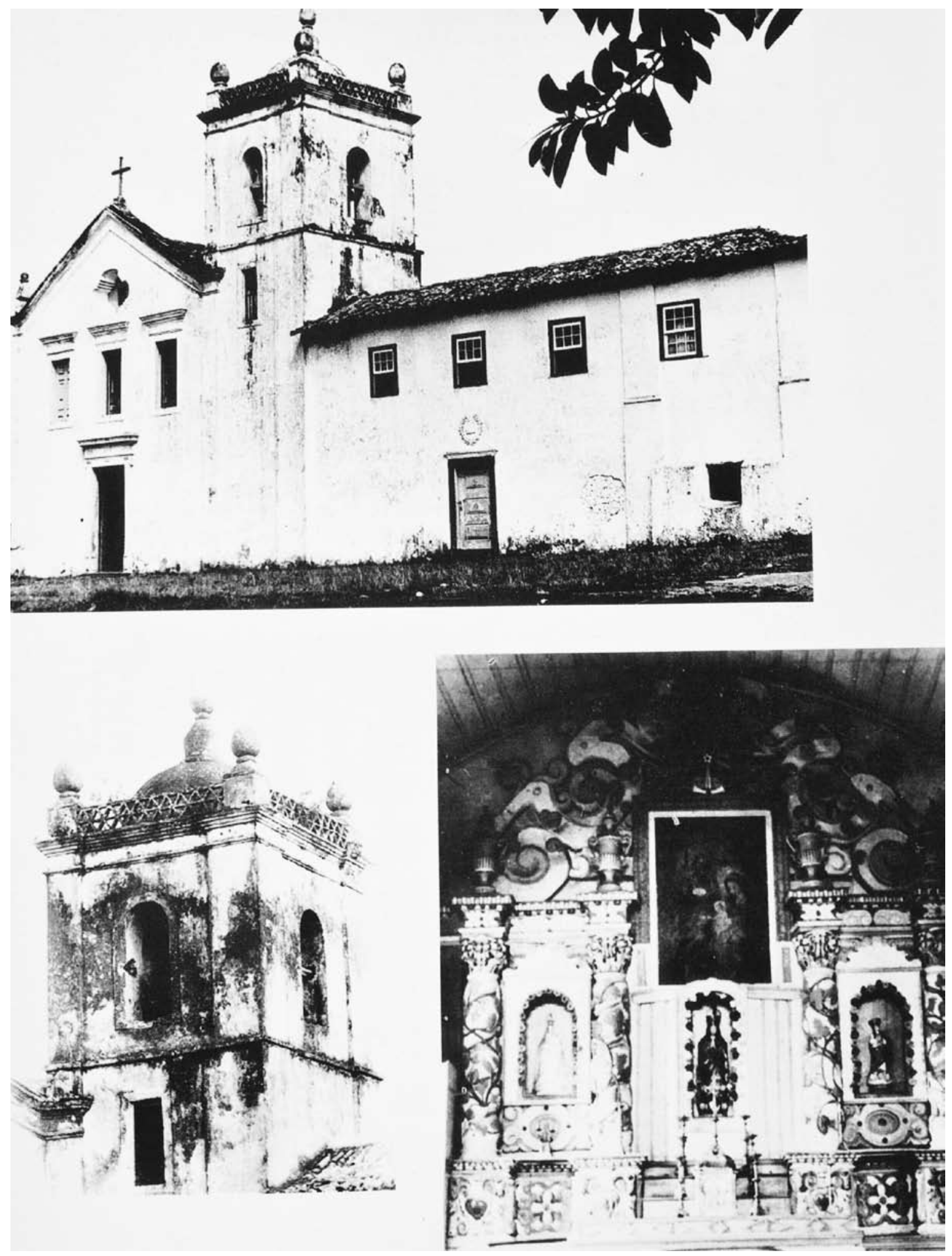


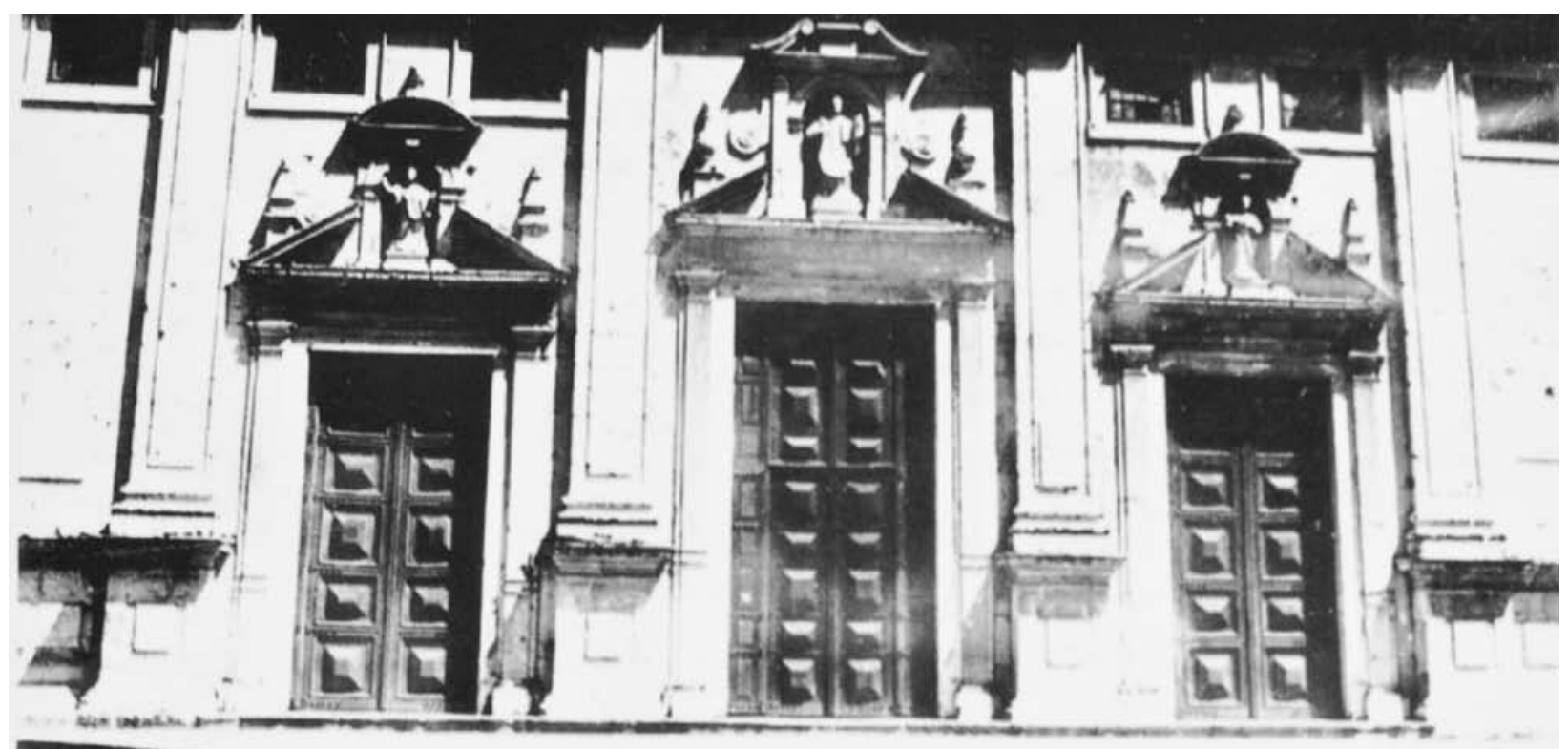

Fig. 19: Portada e Sacrário do altar-mor da igreja do antigo Colégio da Bahia.

Na outra página, fig. 20: Capela-mor da igreja do antigo Colégio da Bahia.

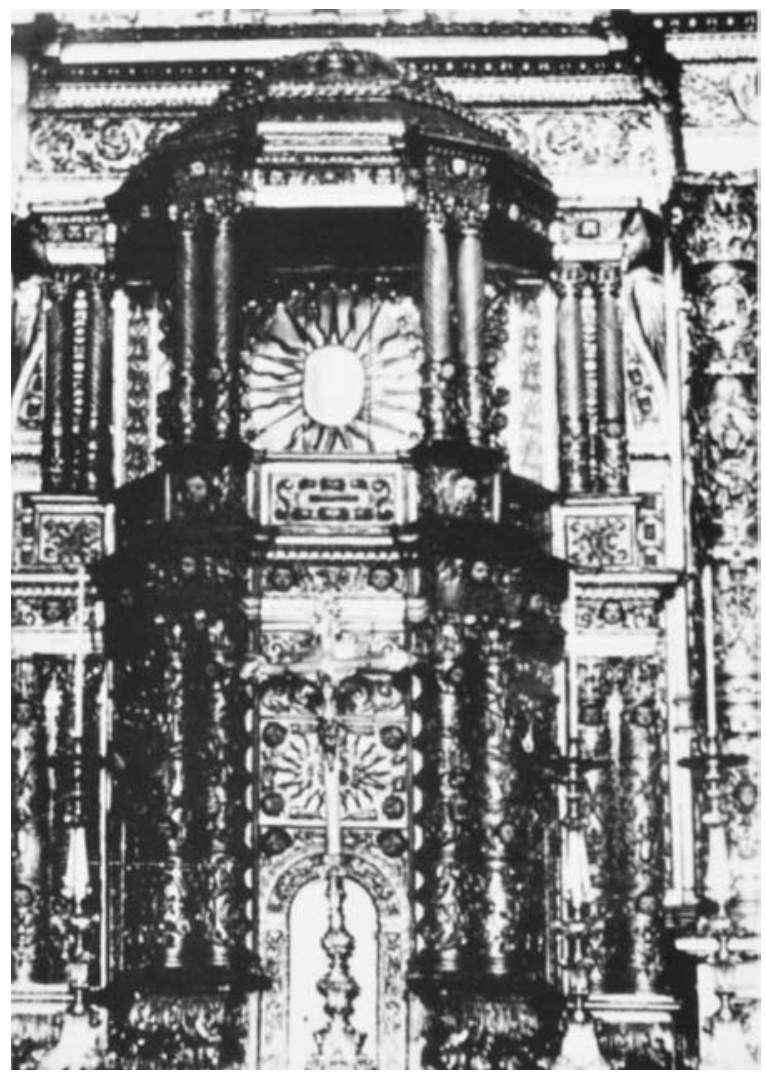




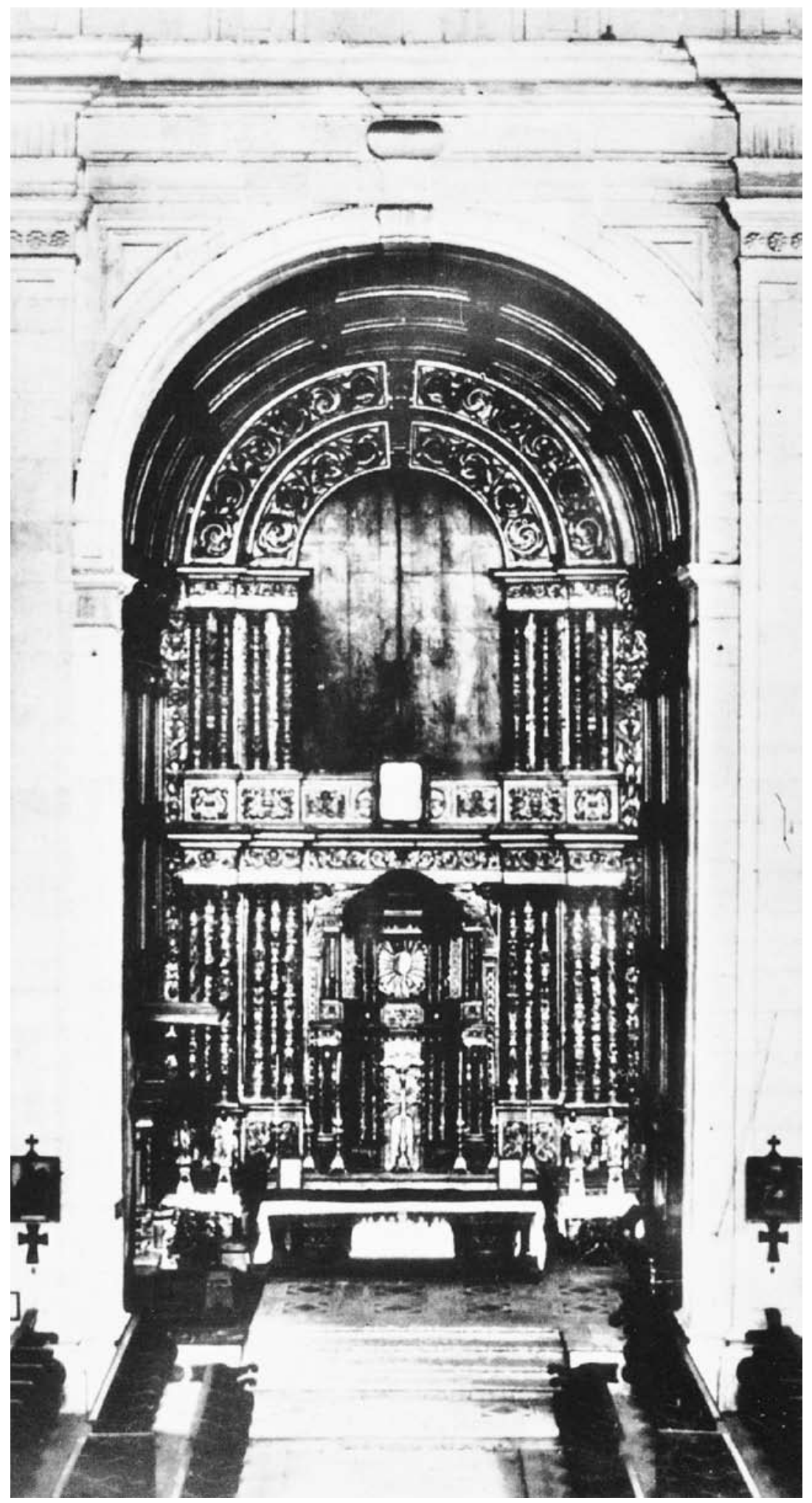


Fig. 21: Corpo inferior e pormenor do retábulo da capela das

Virgens Mártires, na igreja do antigo Colégio da Bahia.
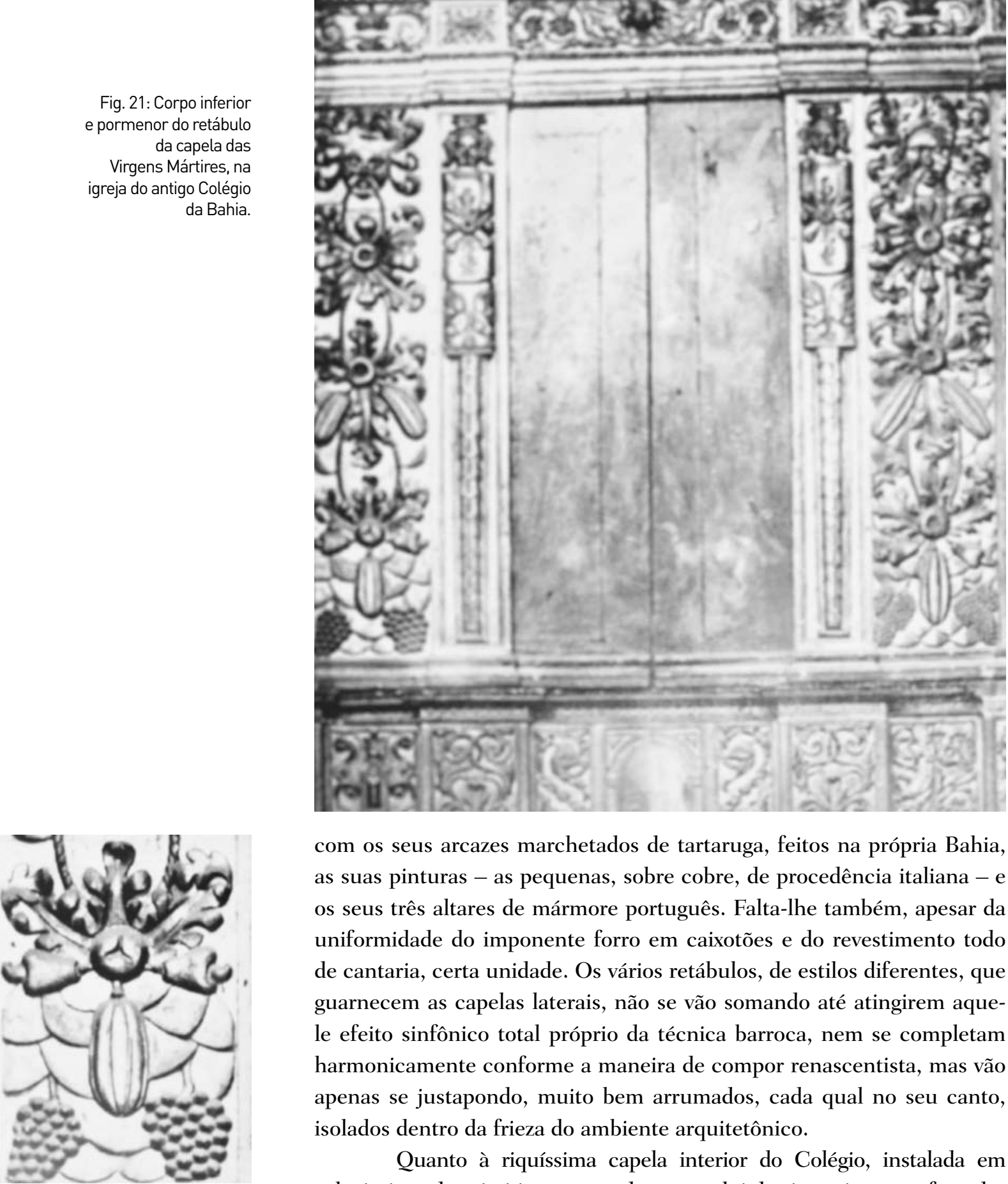

com os seus arcazes marchetados de tartaruga, feitos na própria Bahia, as suas pinturas - as pequenas, sobre cobre, de procedência italiana - $\mathrm{e}$ os seus três altares de mármore português. Falta-lhe também, apesar da uniformidade do imponente forro em caixotões e do revestimento todo de cantaria, certa unidade. Os vários retábulos, de estilos diferentes, que guarnecem as capelas laterais, não se vão somando até atingirem aquele efeito sinfônico total próprio da técnica barroca, nem se completam harmonicamente conforme a maneira de compor renascentista, mas vão apenas se justapondo, muito bem arrumados, cada qual no seu canto, isolados dentro da frieza do ambiente arquitetônico.

Quanto à riquíssima capela interior do Colégio, instalada em substituição da primitiva - segundo se conclui das investigações efetuadas recentemente pelo SPHAN - na própria igreja de Mem de Sá, depois de concluída a igreja atual, foi completamente destruída no incêndio de 1905. Figura nesta revista (fig. 23) uma fotografia dessa capela que, juntamente com a descrição minuciosa - verdadeiro levantamento - feita inspiradamente, dois anos antes do incêndio, pelo ilustre Prof. Brás do Amaral, dão-nos 

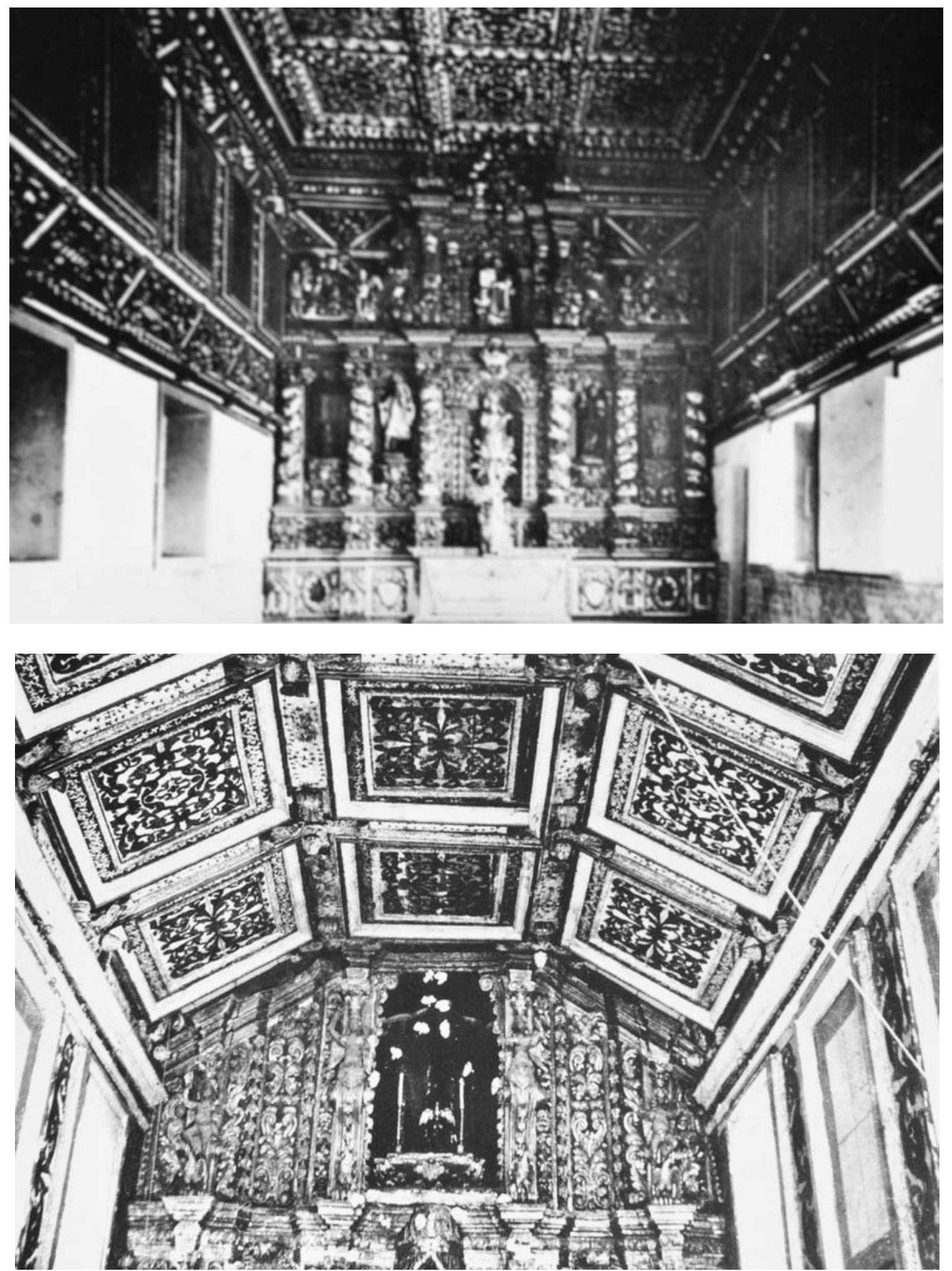
Na págia anterior, fig. 23: Capela interior do antigo Colégio da Bahia, incendiada em 1905 e que ainda aproveitava, ao que parece, o arcabouço da primitiva igreja, construída por Mem de Sá.

Fig. 24: Capela-mor da igreja da Companhia em Embú, São Paulo. porém, independente dos painéis também pintados sobre tábua, mas geralmente a óleo e emoldurados com talha ou desenho de arabescos, que guarnecem as paredes das capelas, das sacristias e os próprios retábulos, verdadeiros "quadros" que, muito embora façam parte da composição arquitetônica, apresentam, tanto do ponto de vista formal como de conteúdo, um sentido pictórico autônomo (fig. VIIb).

Ao segundo grupo correspondem as igrejas de meados e da segunda metade do século XVIII. Conquanto ainda perdure, então, a tradição dos painéis pintados nas capelas e sacristias, inclusive nos tetos, com a única diferença de apresentarem contornos cada vez mais caprichosos (o exemplo das capelas baianas de Santo Inácio e São Francisco Xavier é significativo (fig. VIIc), a pintura dos forros da nave e da capelamor transforma-se completamente, adquirindo enorme importância, de conformidade com a nova concepção ilusionista barroca, inaugurada na Europa no século anterior.

As preferências por esse partido, tão engenhoso, que consiste no emprego de elementos arquitetônicos pintados em perspectiva - balaustradas, colunas, platibanda etc. - procurando-se dar assim a impressão de que a nave se abre, da cimalha real para cima, diretamente para o azul do céu, onde aparecem os santos e Nossa Senhora, num resplendor de glória entre as nuvens e os anjos (fig. VIIe), são a melhor prova de que ainda havia nos artistas barrocos aquela mesma preocupação que atormentou os arquitetos medievais, isto é, a de conseguir exprimir, graças ao recurso de expedientes plásticos e técnicos apropriados, a ideia de ascensão. Apenas, de acordo com o espírito mais objetivo da época, em vez de recorrerem a malabarismos de estereotomia para manterem as ogivas equilibradas a uma grande altura, eles recorreram à pintura e assim atingiram, num salto, o próprio céu.

Essa nova pintura de caráter monumental, eminentemente decorativa, no melhor sentido da expressão, evoluiu do tratamento pesado e opressivo, onde prevaleciam a representação de formas arquitetônicas e o colorido sombrio (fig. VIId), até às igrejas claras, de aparência alegre - quase feliz - dos últimos decênios do século XVIII em Minas Gerais, nas quais Manuel da Costa Ataíde revelou-se mestre consumado (fig. VIIe). As figuras eram então empregadas, da mesma forma que os motivos arquitetônicos e ornamentais, como simples elementos plásticos de composição, um pouco no mesmo espírito das criações, chamadas impropriamente "abstratas", da arte moderna. É que se trata ali, na verdade, de um complemento da própria arquitetura. Sem ela, a igreja ficaria por acabar, já que os forros, em vez dos caixotões moldurados do período anterior, eram então feitos com tabuado corrido 

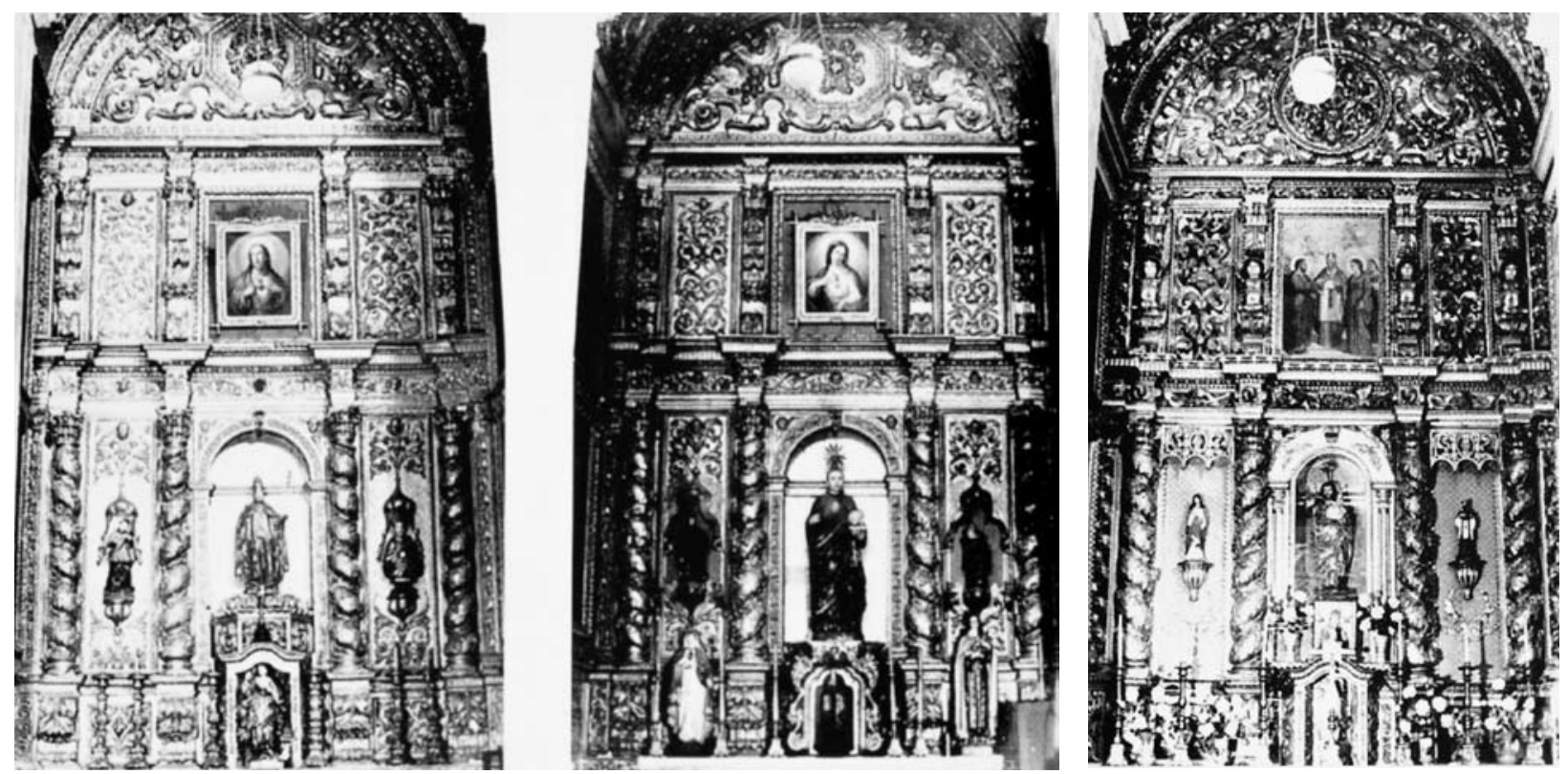

Fig. 25: Retábulo das capelas de São Pedro, São Francisco de Borja e São José, na igreja do antigo Colégio da Bahia. especialmente para receber esse gênero de pintura. E justamente por esse motivo, muitas vezes ela atinge o objetivo arquitetônico visado, sem contudo satisfazer do ponto de vista estritamente pictórico; enquanto noutros casos atende a essa finalidade, mas não corresponde, ou mesmo prejudica, ao partido geral de composição adotado, aquilo que, entretanto, deveria prevalecer, pois, na sua qualidade de pintura ornamental, ela desempenha, no conjunto arquitetônico interno das nossas igrejas da segunda metade do século XVIII, função equivalente à da ensamblagem e da talha.

Aliás, os artistas incumbidos da tarefa encarregavam-se também, geralmente, do douramento, estofagem e pintura dos retábulos e das imagens, assim como do fingimento em "faiscado" das cimalhas de madeira e dos elementos de cantaria que, por seu aspecto mais grosseiro, por ventura destoassem da atmosfera ideal convencionada.

As igrejas da Companhia correspondem principalmente ao primeiro grupo, porquanto a expulsão impediu que as construções iniciadas no século XVIII se concluíssem convenientemente.

No que respeita à imaginária, ainda não pôde ser devidamente recenseada a numerosa população de santos e de santas disseminados por todo o país.

Os jesuítas, particularmente depois da canonização de Santo Inácio e São Francisco Xavier, tiveram que organizar sob moldes eficientes a fabricação de imagens para atender às exigências dos seus numerosos es- 
Fig. 26: Retábulo das capelas de Santa Úrsula e de Sant'Ana, na igreja do antigo Colégio da Bahia.
Fig. 27: Retábulo dos altares-mores dos antigos Colégios de São Luís do Maranhão e de Campos, no Estado do Rio de Janeiro.
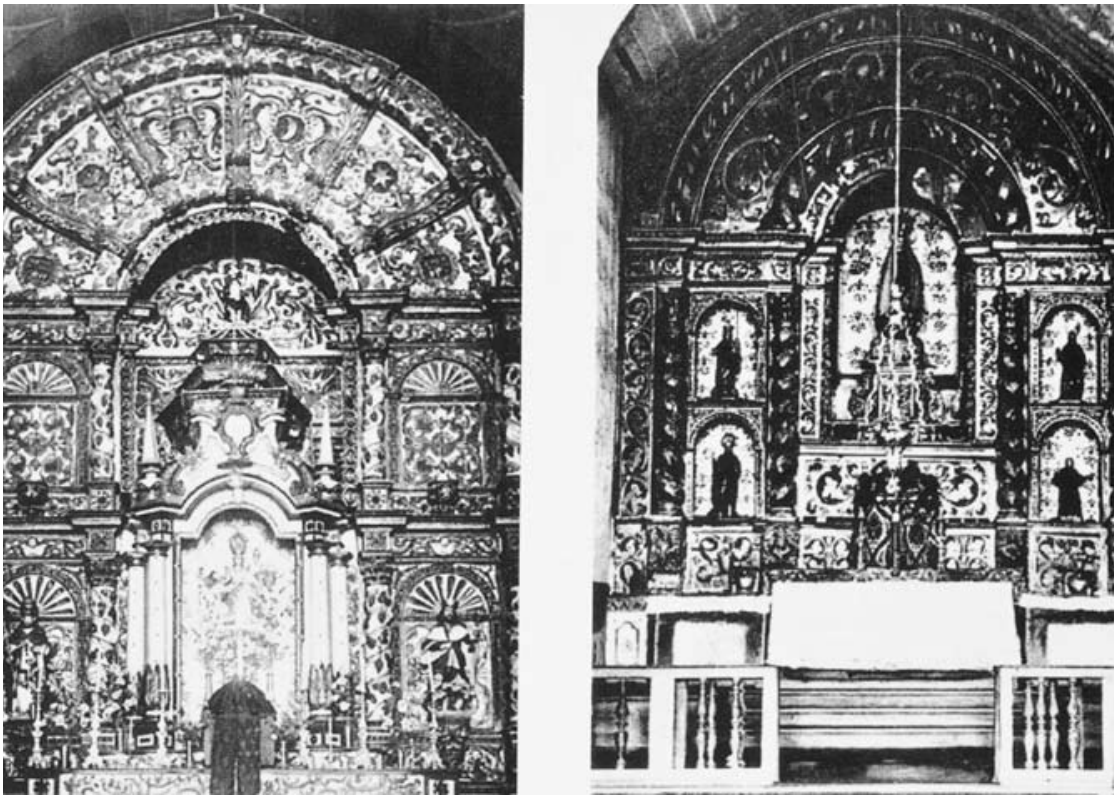

tabelecimentos espalhados pelo mundo. E muito embora as demais ordens também produzissem em grande escala, os padres talvez possam ser considerados como os precursores dos modernos processos de fabricação: a talha, a encarnação, o estofamento eram então feitos em série, o que não excluía, aliás, um grande apuro, tanto no feitio como no acabamento, conseguindose assim santos bonitos, apesar de copiados e recopiados seguidamente. Mas, se os modelos não mudavam de ano para ano, nem por isso deixaram de evoluir, acompanhando as variações do estilo, do gosto e da moda, passando gradativamente das atitudes hirtas iniciais (fig. VIIf) às de contornos esvoaçantes e sinuosos (fig. VIIg), conforme se pode observar nas imagens dos dois últimos retábulos baianos de Santo Inácio e São Francisco Xavier a que nos temos referido por mais de uma vez (fig. 37).

Conquanto os padres costumassem, de preferência, mandar vir as suas imagens da Europa - ao contrário do que sucedeu nos Sete Povos das Missões - muitas delas, inclusive, talvez, o belo Cristo morto em barro cozido da igreja de Geru, eram feitas mesmo aqui, por artistas portugueses ou brasileiros natos, como foi o caso do grande escultor seiscentista carioca, frei Agostinho de Jesus, cuja obra está sendo estudada, juntamente com a de outros notáveis artistas beneditinos, pelo erudito historiador dom Clemente Maria da Silva-Nigra , O. S. B., por incumbência especial do SPHAN.

Ao conjunto arquitetônico interno das igrejas barrocas, constituído principalmente pela obra de talha dos retábulos e pelas pinturas dos forros e paredes, e acessoriamente pelos demais elementos necessários ao culto - al- 


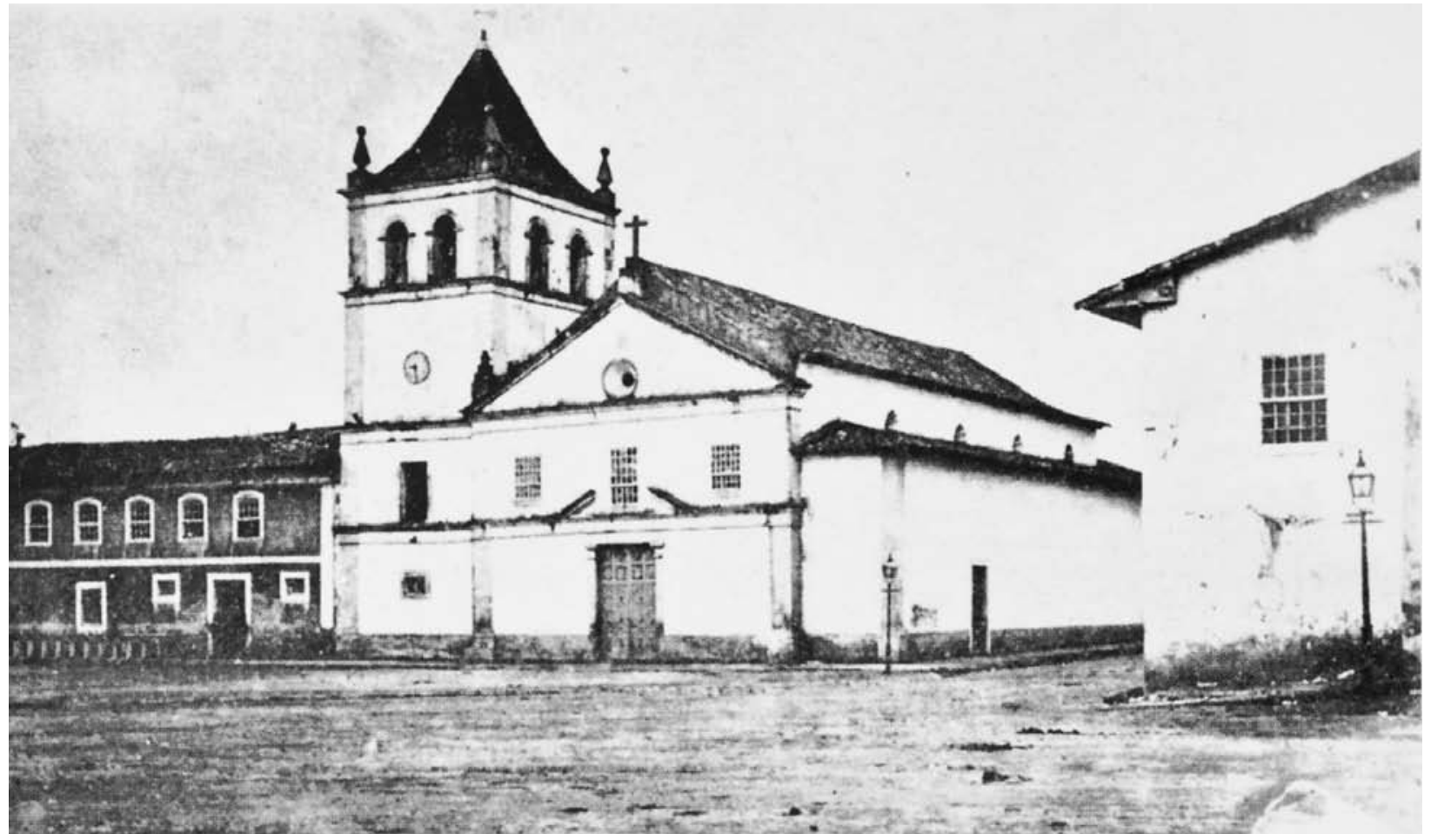

Fig. 28: Frontispício e retábulo de um dos altares das capelas laterais da antiga igreja do Colégio de São Paulo.

Fig. 29: (à direita) Retábulo de um dos altares colaterais da igreja jesuítica de Embú.

Na outra página, Fig. 30: Um dos pequenos retábulos dos antigos altares colaterais da capela paulista de Santo Antônio, no município de São Roque.
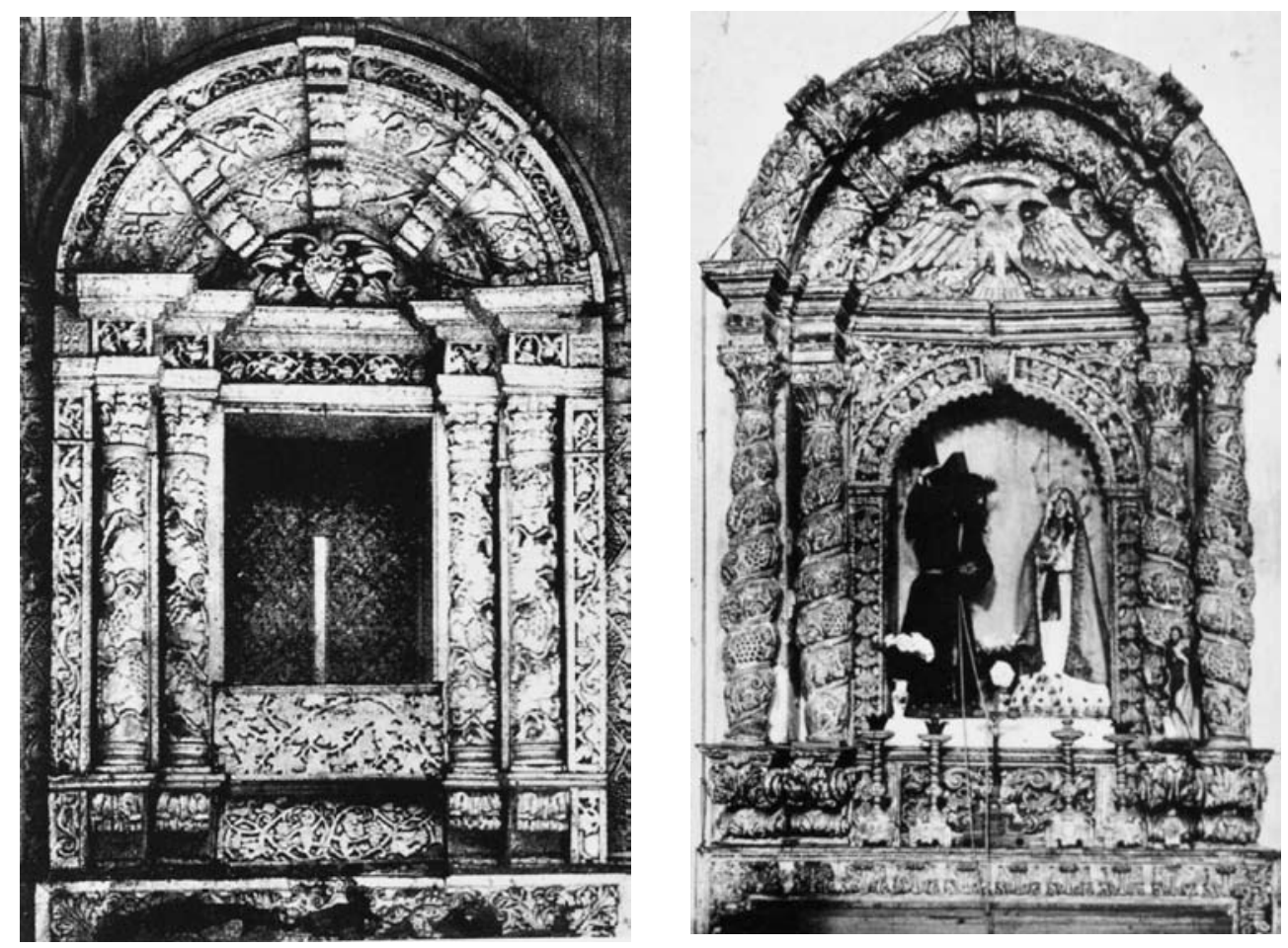


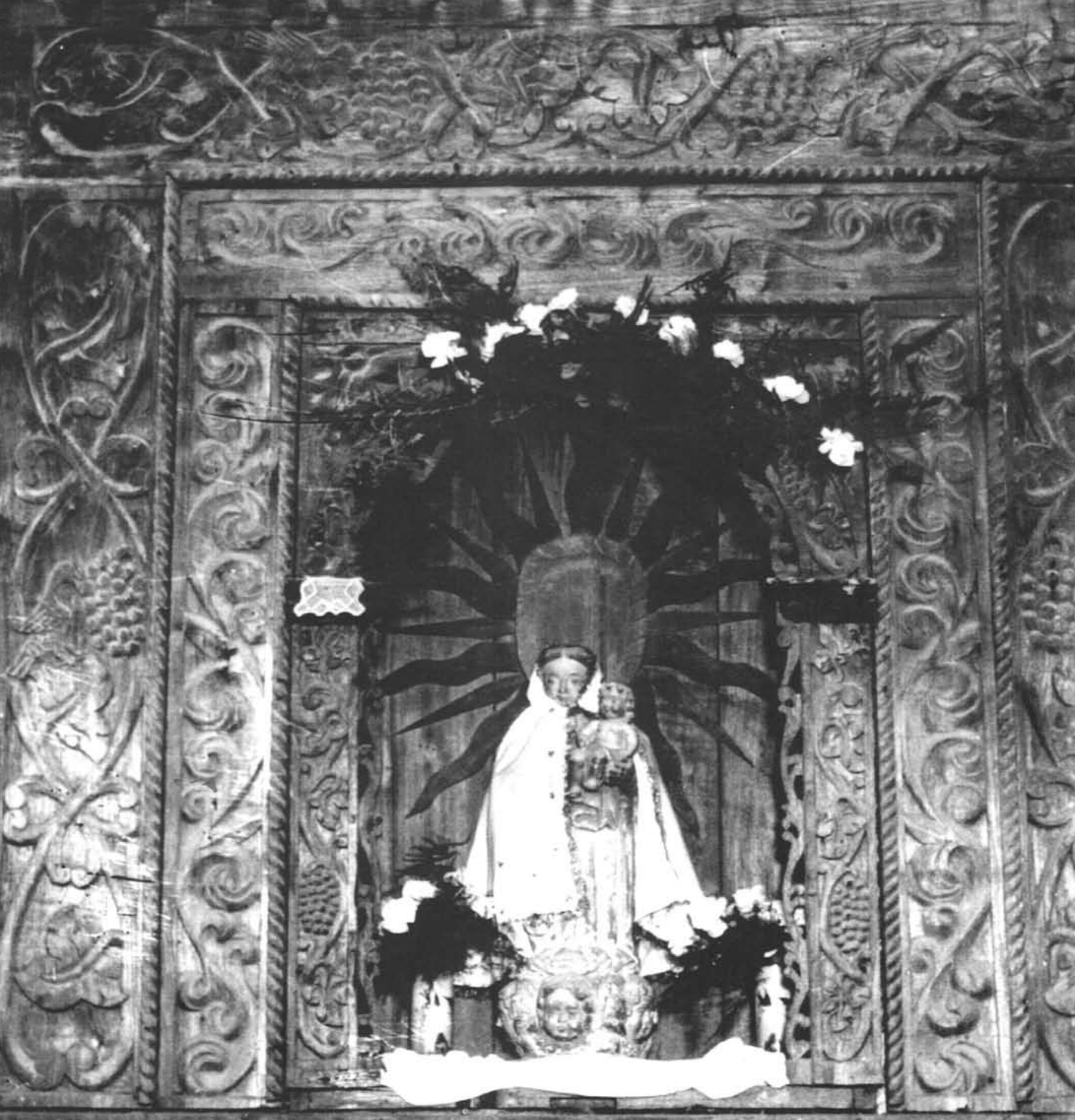

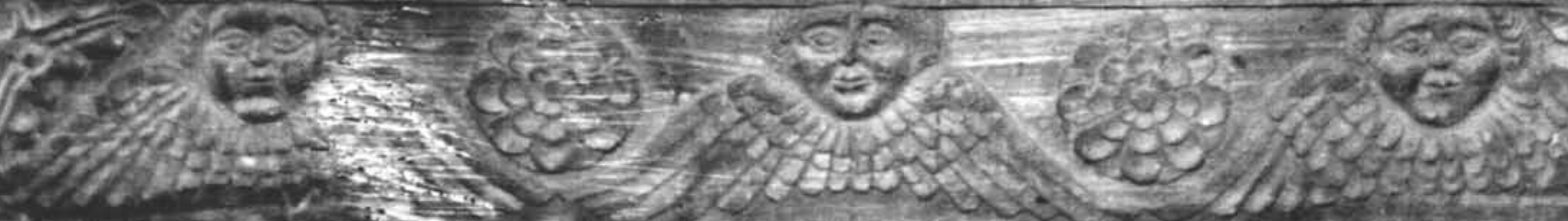



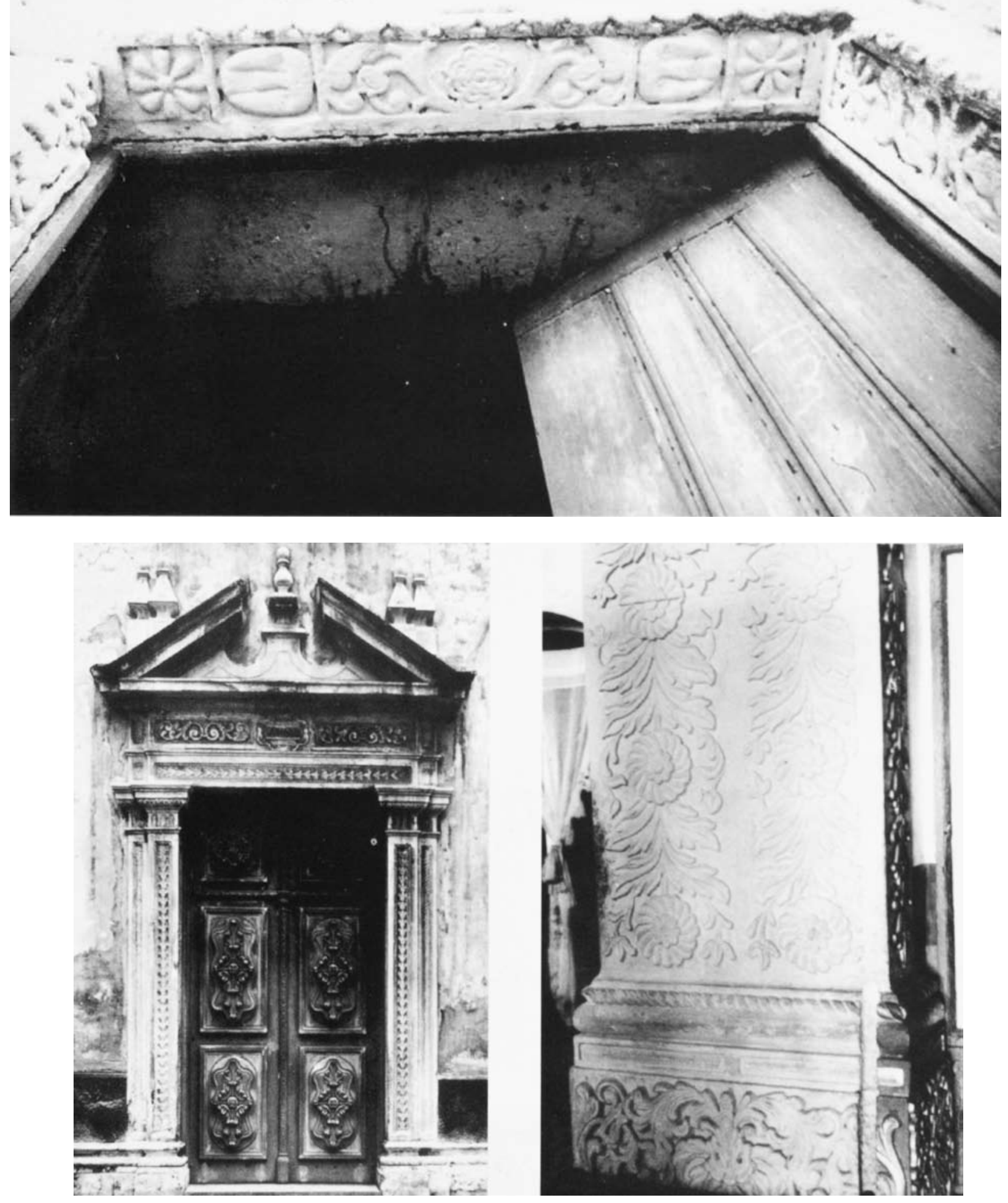
Na página anterior, fig. 31: Portais decorados da capela do chamado engenho Retiro e da igreja do Socorro, em Sergipe, e da igreja do Espírito Santo no Recife.

Fig. 32: Frontispício da igreja jesuítica de São Pedro d'Aldeia, no Estado do Rio e casa de residência dos padres no chamado Colégio em Sergipe.
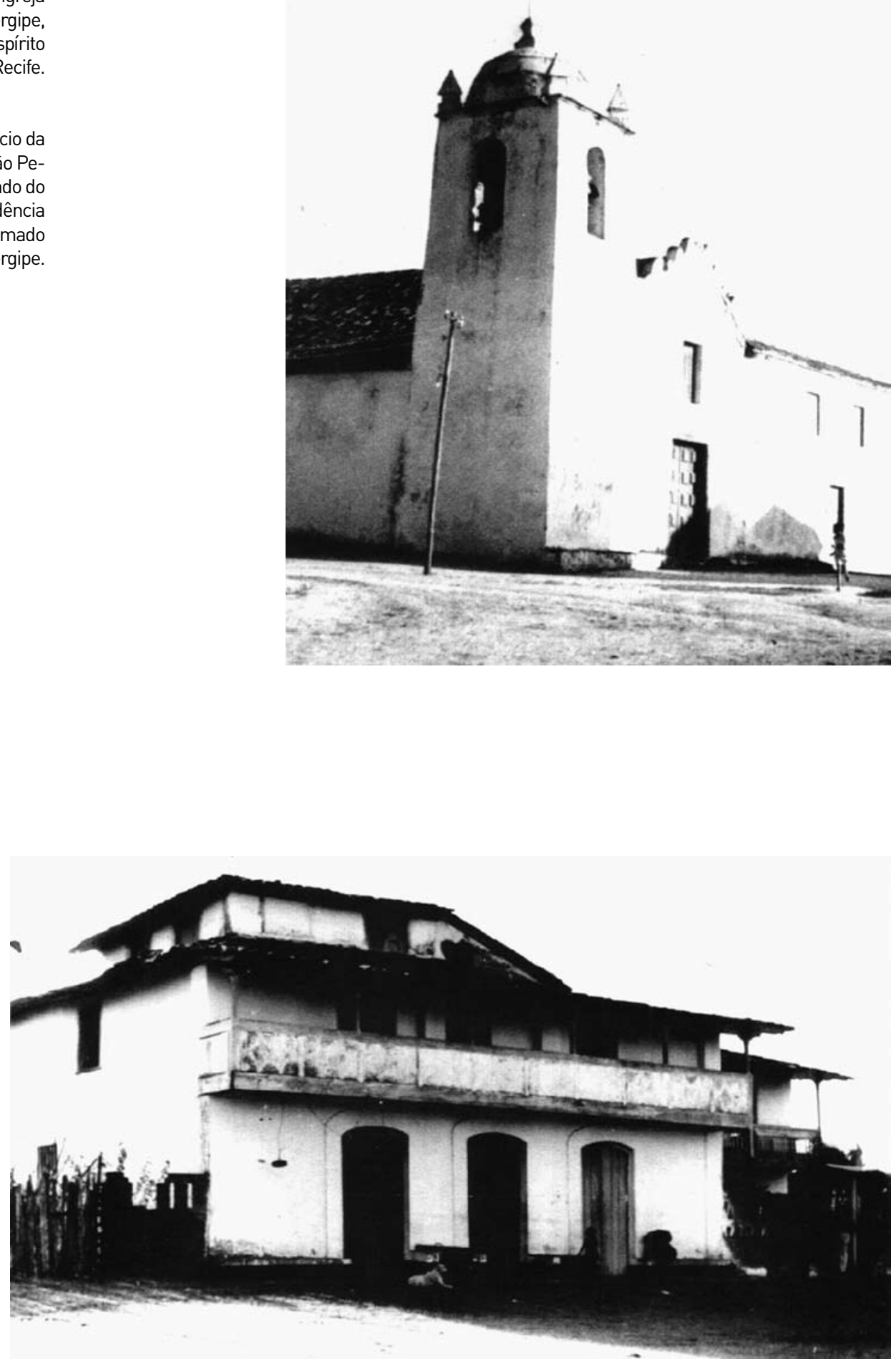


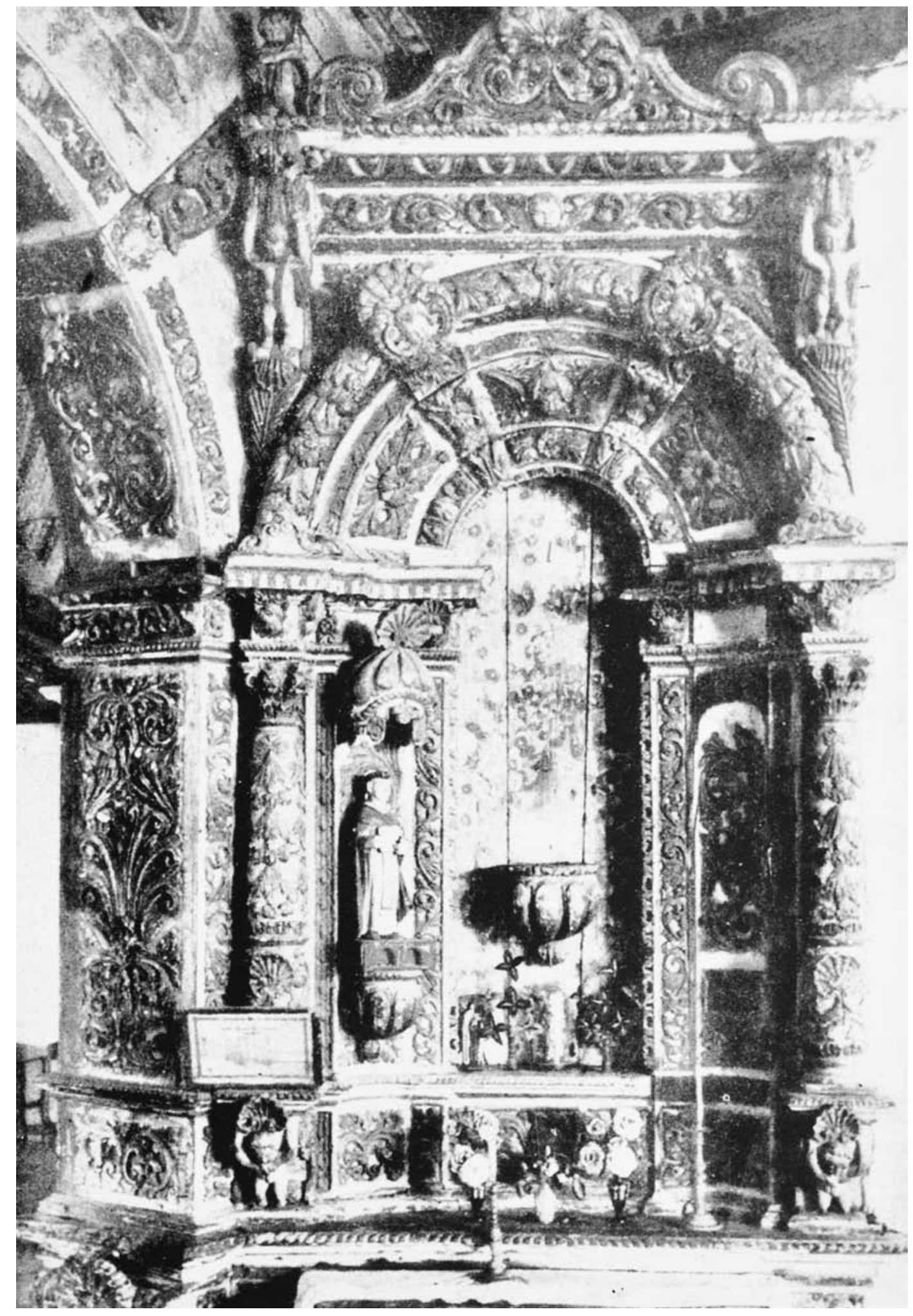


Na página anterior, fig. 33: Retábulo de um dos altares colaterais da antiga igreja de Gerú, em Sergipe.

Fig. 34: Púlpito da igreja de São Francisco Xavier, hoje de Santo Alexandre do antigo Colégio de Belém, do Pará.
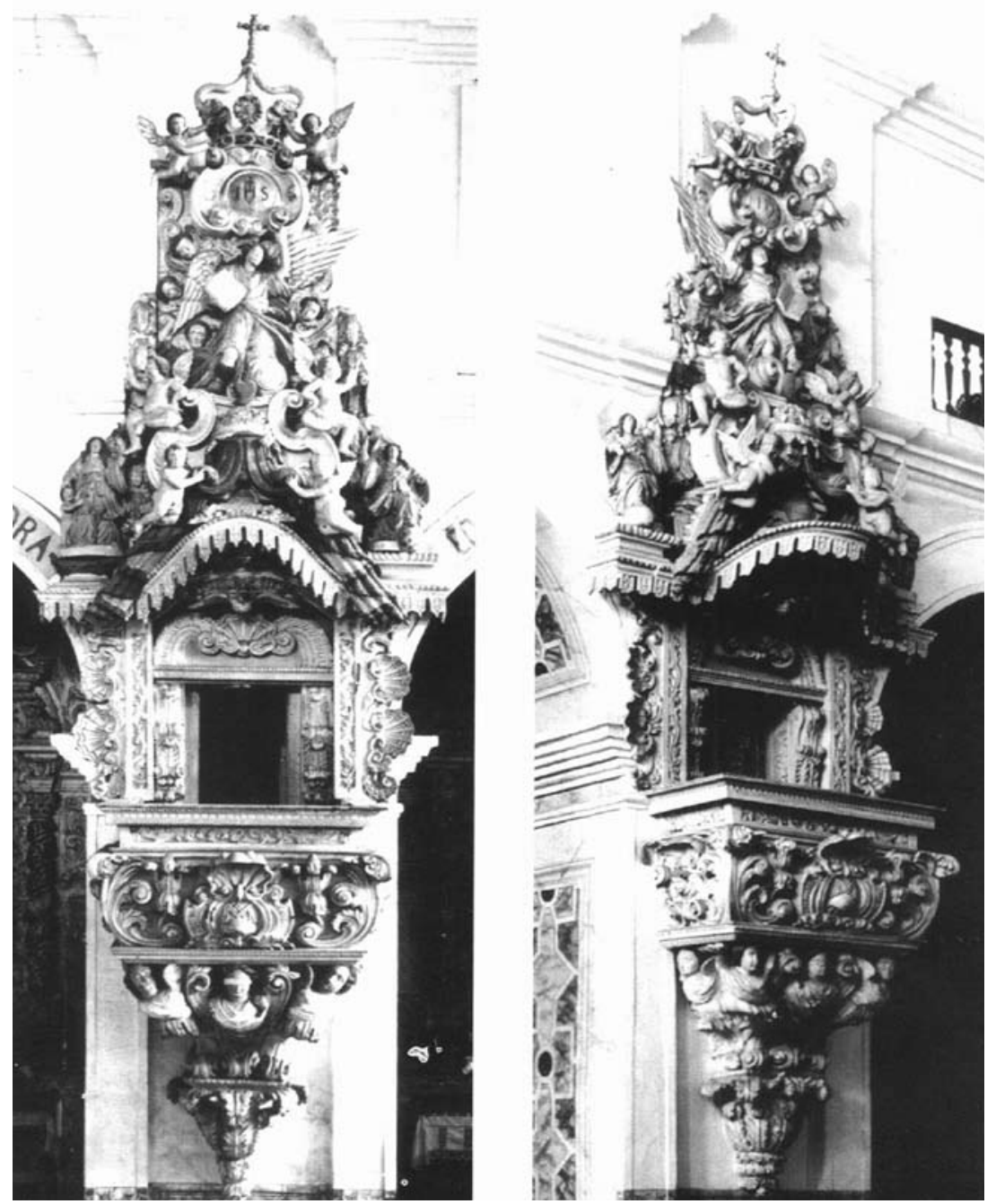

faias, imaginária etc. - conjunto a que se designa, às vezes, por "suntuária", expressão imprópria e antididática, por isso que atribui a elementos orgânicos fundamentais, tanto do ponto de vista plástico como funcional, da arquitetura interior das igrejas, um sentido de coisa supérflua ou acrescentada - a esse conjunto, costuma-se associar a ideia de teatro ou de salão.

Esta imagem, no fundo, afinal, pejorativa, não deve ser aceita assim sem maior exame, mormente no que diz respeito às nossas igrejas - muito particularmente às jesuíticas, geralmente concebidas dentro do melhor espírito litúrgico - a fim de restringi-las às suas devidas proporções.

Compreende-se, com efeito, que para o europeu de uma boa parte da Europa - habituado com o "partido" das igrejas medievais, onde o altar-mor fica solto e como que perdido em meio da nave, não 
Fig. 35: Altar colateral da igreja do Colégio, em Campos.

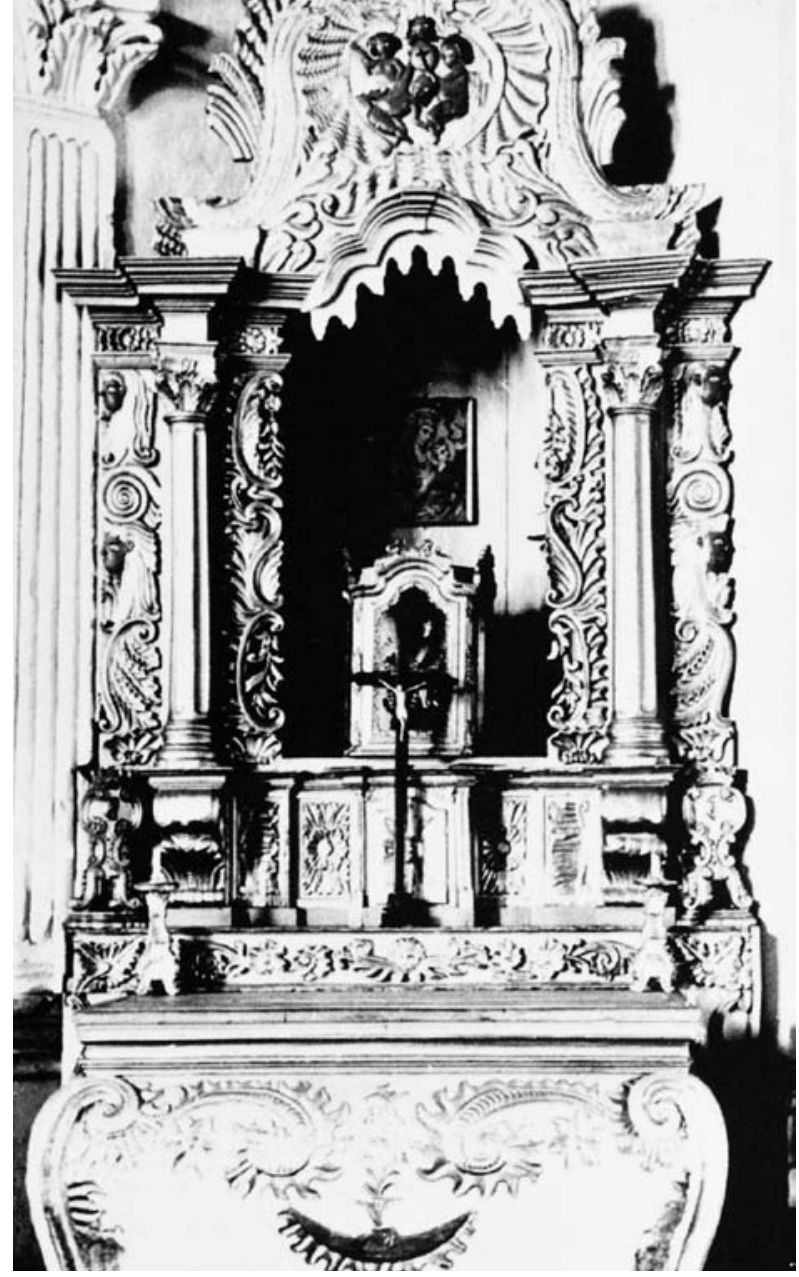

passando o retábulo de um biombo armado para lhe fazer fundo, pois que a igreja ainda continua, pelo avesso desse altar, com o coro, a abside, o deambulatório e as absidíolas - a primeira impressão ao entrar nas nossas igrejas seja realmente essa, isto é, a de um ambiente cenográfico e aparatoso, porque diferente da cenografia e do aparato que lhe são familiares. Tanto mais que, frequentador assíduo dos teatros de estuque dourado do século XIX, não lhe ocorrerá, de pronto, que o ouro das nossas igrejas já era "velho" quando o teatro dourado das suas reminiscências talvez ainda nem sequer estivesse construído.

Para nós, porém, a imagem parecerá sempre artificiosa e insincera, porquanto a nossa ideia de igreja não está, de forma alguma, condicionada à lembrança das igrejas góticas. Pelo contrário, igreja, para nós, é mesmo assim: é o coro logo por cima da entrada; é a nave com as suas tribunas e os púlpitos em evidência; é o arco cruzeiro; é o altar-mor com seu retábulo, bem resguardado lá no fundo da capela e para onde converge toda a composição, uma vez que a igreja acaba de fato ali.

Igreja barroca não é, portanto, nem salão nem teatro - é simples- 
mente igreja. E a "encenação" das nossas igrejas jesuíticas, como a de todas as demais, foi tão legítima quanto o foi a "encenação" das igrejas góticas, cada qual a seu modo, de acordo com a sua época. Porque o "estilo" das igrejas nunca foi uma coisa à parte, divorciada do estilo das construções contemporâneas comuns. Quando as catedrais eram "góticas", também eram góticos o edifício da municipalidade, a casa das corporações, o castelo e a cozinha do castelo. Quando as nossas igrejas se faziam de pau-a-pique, de taipa de pilão ou de pedra e cal, as casas dos governadores, as "casas de Câmara e cadeia" e as casas de morar de toda a gente também eram feitas com a mesma técnica, repetindo, umas e outras, os mesmíssimos pormenores e obedecendo à mesma comodulação. As diferenças de aspecto decorriam, muito naturalmente, das diferenças de programa, de proporções e de intenção. E se a igreja pretende, como sempre fez no passado, acertar o passo com os tempos - rumo a essa Nova Idade que deverá surgir da débacle atual - terá de construir as casas de Deus do mesmo jeito que se faziam, já desde 1854, os chamados "palácios de cristal" e como se fazem as fábricas hoje em dia, não para se tornar mais burguesa ou para se proletarizar, mas, simplesmente, porque foi naquelas estruturas de exposição e nestas de caráter industrial que a nova técnica de construir e o estilo dela decorrente puderam desenvolver-se sem compromissos, em toda a sua pureza, pela primeira vez. Daí concluírem apressadamente certos críticos e, com eles, a opinião pública, tratar-se de uma técnica menos digna e apenas tolerável, em edifícios "que se prezem" (as igrejas, por exemplo), escondida sob o arremedo de um estilo de outra época, ou então disfarçada pelo incrível decorativismo pseudomoderno, como se fosse possível o advento e a aceitação generalizada de uma nova técnica desligada do estilo que lhe é próprio.

E agora, ao finalizar, uma vez que se trata aqui de arquitetura jesuítica no Brasil, e não apenas do Brasil, não podemos deixar sem uma referência especial a grande obra realizada pelos padres nos chamados Sete Povos das Missões, obra que, pertencendo embora à Província Jesuítica do Paraguai, ficou definitivamente encravada em território nacional, constituindo assim um setor autônomo no conjunto dos monumentos coloniais brasileiros, verdadeira "minoria" - a única, uma vez que os holandeses, apesar das carpintarias vistosas de Boa Vista e de Freiburgo, pouco ou quase nada deixaram, neste particular, em troca do muito que destruíram ou impediram se concluísse, como se pode facilmente aferir ao simples exame dos panoramas de Olinda, pintados por Franz Post.

Essa arquitetura jesuítica nada tem a ver, de fato, com a arquitetura jesuítica da Província do Brasil, ao contrário do que, inadvertidamente, já se deu a entender. A nossa interferência no caso foi apenas demolidora: conseguimos desmontar, peça por peça, a obra singular criada pelo gênio co- 
13

$\infty 6$ 1.
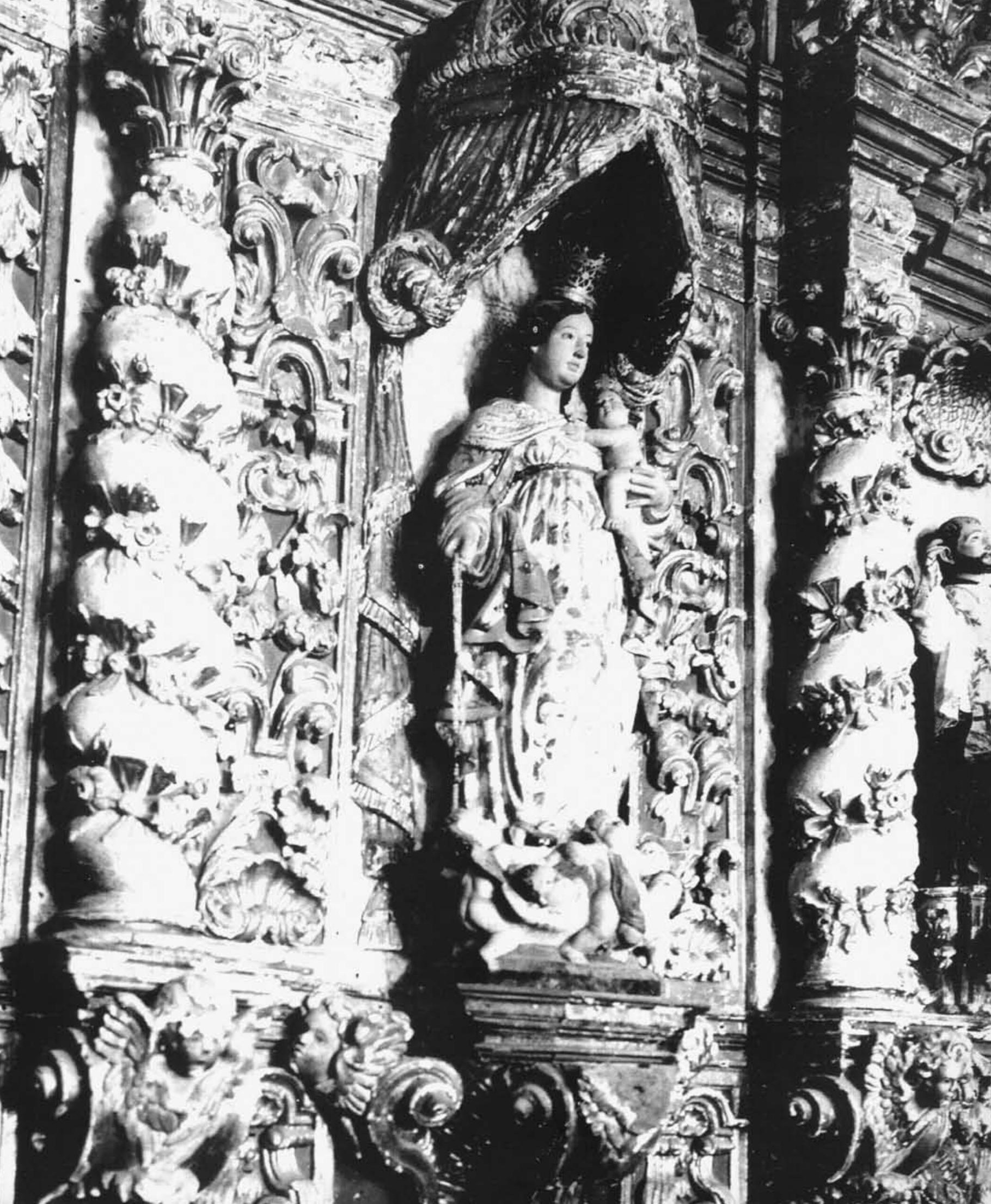

24inte

\section{$-17$ \\ करत को}

\section{t.}

(1)

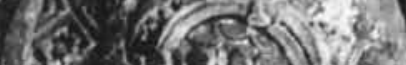

Q⿻日木

6

31) $\operatorname{lic}^{2}$

सै:

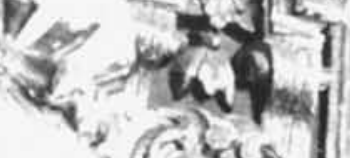

ixery

$\frac{2}{2} e^{\circ}$

tim

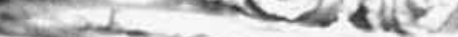

)

त) 3 (1)

.
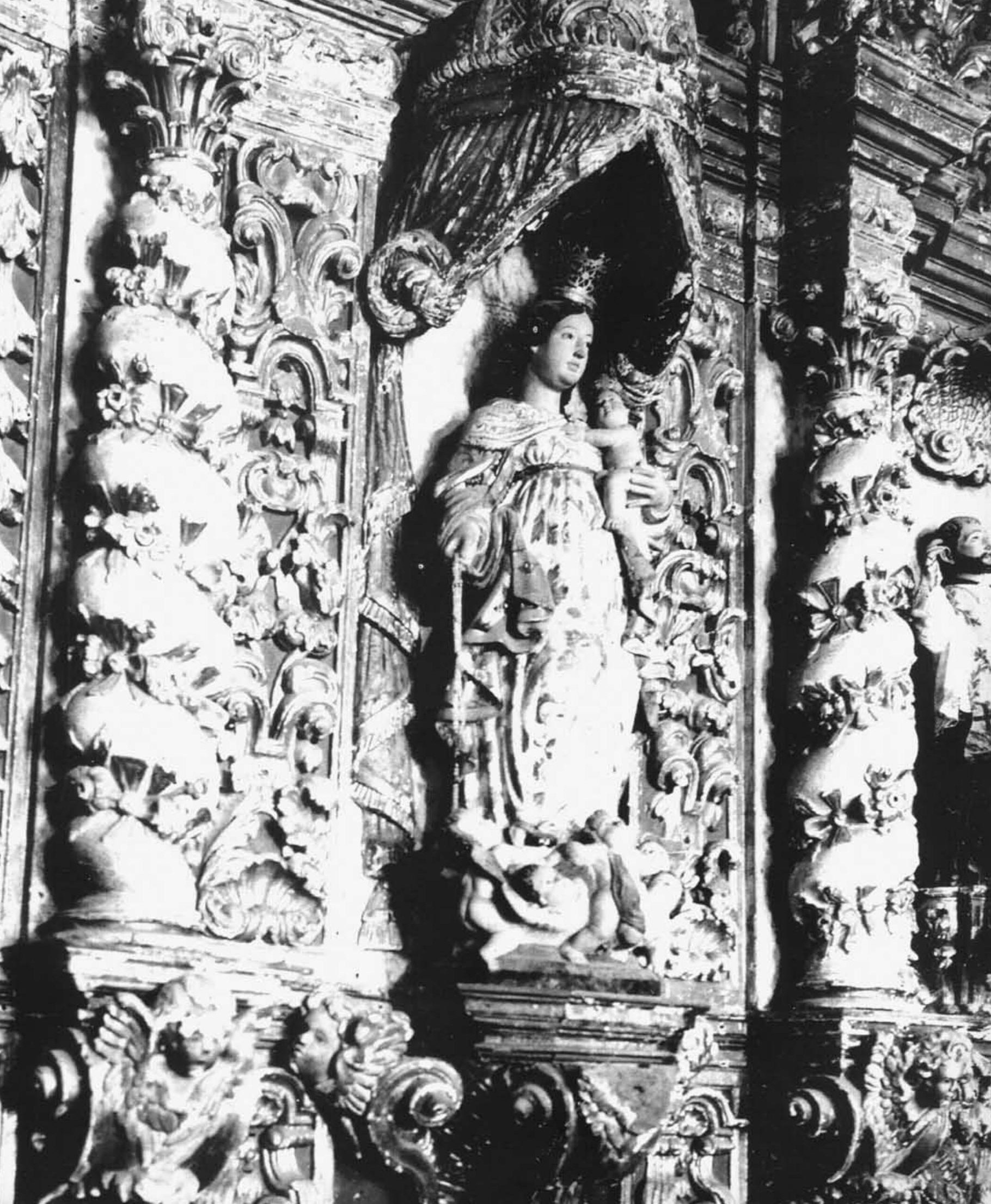

for

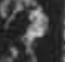


Fig. 36. Pormenor do retábulo do altar-mor da igreja de Embu, em São Paulo. lonizador e sob a tutela dos padres. E o arrasamento teria sido total, não fosse a intervenção de urgência procedida pela Comissão de Terras, em 1928, em São Miguel, e, finalmente, as obras de estabilização e recomposição do que ainda resta das ruínas desse povo, realizadas pelo SPHAN, desde 1938, com a reconstrução da torre desaprumada e do cunhal tombado do pórtico, pelo processo da dépose - que a experiência demonstrou ser, no caso, o único aplicável - recolhendo-se em seguida, a um pequeno museu local, as peças que, sobrevivendo à catástrofe, por assim dizer, "deram à praia": capitéis, cartelas partidas, ainda com o IHS, os três cravos e a cruz, imagens mutiladas e já sem cor - peças cuja vista nos deixa uma impressão penosa e certo mal-estar, como se realmente estivéssemos diante dos destroços de algum naufrágio.

Só mesmo quando se percorreram um a um, esses povos, repetindose a peregrinação feita em fins do século passado pelo Sr. Hemetério Veloso, simpático pernambucano, cujo depoimento é, hoje, dos mais valiosos, pois que ainda havia ali, então, muita coisa para ver; quando se estuda a história dramática da instalação das primeiras "reduções" e das lutas que antecederam ao definitivo abandono e, ainda, documentação antiga referente à arquitetura missioneira - é que se pode ajuizar e reconstituir mentalmente o que foram esses povos na época do seu florescimento, quando, como diz tão bem o Sr. Augusto Meyer, na bruma da manhã, cada dia, todos aqueles índios saíam das casas, atravessando o terreiro em direção da igreja: Santo Ângelo, São Luiz Gonzaga, São Borja - cidades que, não fossem a praça e uns poucos vestígios isolados, já teriam esquecido completamente o aspecto primitivo: São João Batista, São Miguel Arcanjo, São Lourenço e São Nicolau - ruínas perdidas naquele ermo da campanha riograndense, com uma ou outra casa próxima, construída com material antigo, ou certo número delas formando novo povoado.

Cada povo - isto é, cada burgo - era constituído pela igreja, que compunha com a residência dos padres, o asilo, a enfermaria, as aulas, as oficinas, as cocheiras etc., e também com o cemitério, um grande conjunto arquitetônico, servido por vários pátios, tudo murado, muro que se continuava para os fundos das construções, abraçando a enorme área ocupada pelo pomar e pela horta, ou seja, a quinta dos padres (fig. VIIh).

Em frente à igreja, havia um grande terreiro ou praça, em volta do qual eram dispostos numerosos blocos de habitação coletiva, composto cada um de muitas células de cinco metros por sete, aproximadamente, verdadeiros apartamentos com porta e janela e construídos com paredes de pedra ou de barro, morando em cada um deles uma família de índios. Um passeio alpendrado circundava esses blocos de habitação que constituíam assim, por si mesmos, verdadeiros quarteirões (fig. VIIi). Os primeiros blocos construídos eram os que formavam a praça; depois, à medida que o povo crescia, novos blocos eram edificados paralelamente aos primeiros, surgindo dessa forma, 


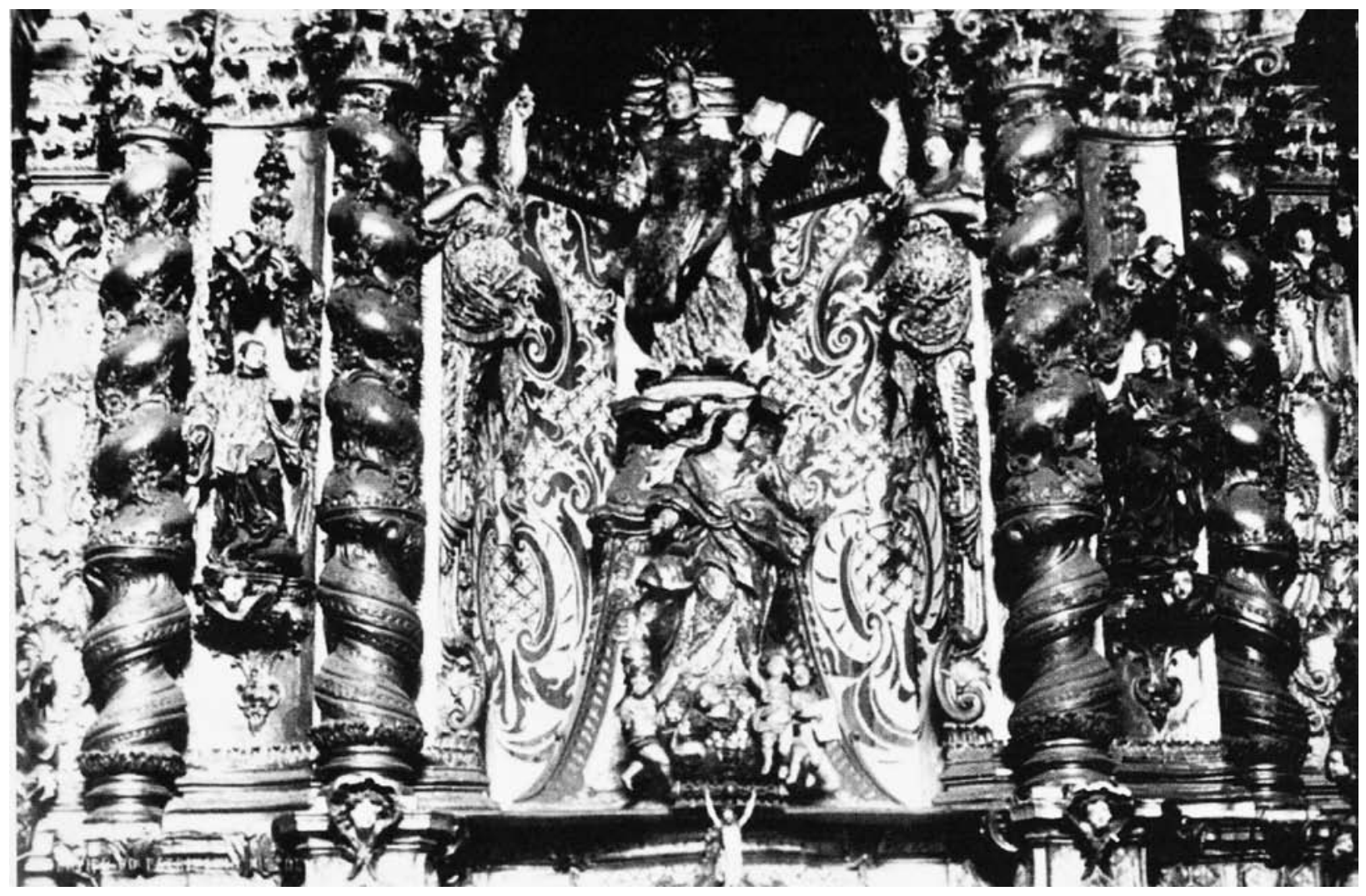

entre eles, numerosas ruas, todas em esquadro à moda espanhola, de conformidade, aliás, com o estipulado no Livro IV, Título Sete, das Leyes de Indias: De La población de las ciudades, Villa y pueblos. O edifício do Cabido ocupava, geralmente, a extremidade da praça oposta à igreja.

Esses povos, com as respectivas estâncias para criação de gado, ficavam a uma distância razoável uns dos outros, formando a sequência deles um todo orgânico e perfeitamente articulado.

Transcreveremos aqui, para concluir, alguns trechos do relatório feito em 1937, quando, por determinação da direção do SPHAN, visitamos seis destes povos:

A planta de todos eles obedecia a um padrão uniforme preestabelecido. Os quarteirões, com as colunas dos alpendres em fila e bem alinhadas, arrumavam-se como regimentos em volta da praça. Tudo se distribuía e ordenava com uma disciplina quase militar. Os jesuítas revelaram-se, nestas Missões, urbanistas notáveis, e a obra deles, tanto pelo espírito de organização como pela força e pelo fôlego, faz lembrar a dos romanos nos confins do império. Apesar do atual desmantelo, ainda se adivinha, nos menores fragmentos, uma seiva, um vigor, um "impulso", digamos assim, que os torna - estejam onde estiverem - inconfundíveis. 


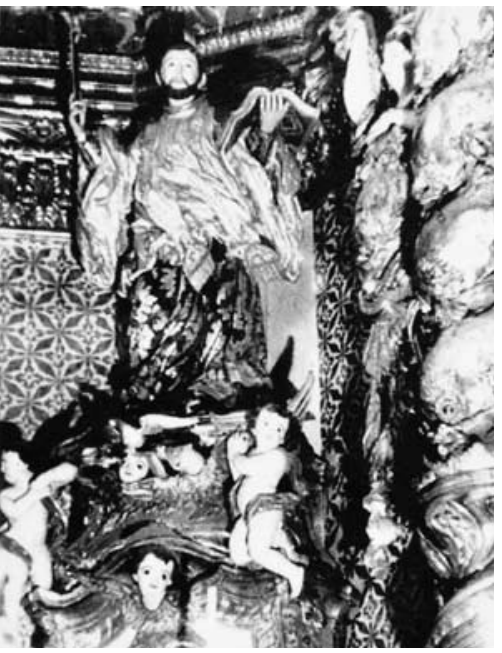

Fig. 37: Pormenores dos retábulos das capelas de São Francisco Xavier e Santo Inácio, na igreja do antigo Colégio da Bahia.
Enquanto na composição e na talha do único retábulo existente e em muitas das imagens, devido às proporções "diferentes" ou à expressão orientalizada, ainda se pode sentir, por detrás do convencionalismo europeu, o guarani, não encontramos nos elementos de arquitetura estudados, ao contrário do que se observa nos povos da outra banda do Uruguai, vestígios senão muito vagos de influência indígena. Aqui, o tratamento mais tosco de umas tantas peças, a aspereza do desenho de certos motivos e, por vezes, a maneira especial de "ornamentar" provêm não só da falta de experiência dos operatórios e daquela gaucherie que aproxima os "bárbaros" de qualquer raça quando pretendem reproduzir de "ouvido" os elementos da arquitetura greco-latina, mas, também, da colaboração de escultores do centro e do norte da Europa, que não foram poucos os que vieram juntamente com os italianos e espanhóis, trazendo com eles aquele renascimento retardatário e impregnado ainda de gosto gótico e até mesmo românico, que durante tanto tempo se manteve ali, lado a lado com o desenvolvimento da escola erudita e latina. Provêm, repito, talvez mais dessa mistura de procedências diversas combinadas com as deficiências do meio, do que, propriamente, da influência do elemento nativo. Este, vencida a primeira fase de rebeldia, deixou-se moldar com docilidade pela vontade poderosa do jesuíta. Parece mesmo não ter havido da parte dos irmãos, cientes da "superioridade" de sua própria técnica, compreensão e simpatia pelo que as interpretações dos indígenas pudessem apresentar de imprevisto e pessoal, e que desprezavam como "errado" tudo que fugisse às receitas do formulário europeu, estimulando, pelo contrário, as cópias servis e assim impondo, junto com a nova crença e a nova moral, uma beleza já pronta.

Com relação a São Miguel, cuja igreja foi construída em obediência a um projeto diferente do de todas as demais igrejas missioneiras, tanto no espírito como na forma (fig. 38), observamos, então, o seguinte:

[...] estranhei de ver em construção de tanto "estilo", uma fachada assim, com dois frontões, um no corpo da igreja e outro, maior, no pórtico, como indica a gravura de Demersay - redundância pouco aceitável em composição de arquitetura (fig. VIIj).

Ora, verificamos, logo da primeira visita, uma estranha particularidade, sobre a qual, entretanto, não havíamos encontrado a mais ligeira referência em nenhum dos autores que tratam de São Miguel, nem mesmo no relatório apresentado pelo Sr. João Dahne. É que as paredes do pórtico estão apenas "encostadas" ao corpo principal, sem qualquer amarração, morrendo de encontro aos capitéis, cornijas e arquitraves deste último, de qualquer jeito, tendo sido ele, portanto, construído depois de completamente pronta a fachada da igreja (fig. VIIk). O mais estranho, porém, é que a sua arquitetura, tanto no conjunto como nos pormenores, revela, da parte de quem a projetou e dos que o executaram, conhecimentos seguros de "modenatura" e proporção, senão mesmo muito apuro. Como compreender, então, que artistas assim "informados" incorressem naquela falta e tolerassem os remates grosseiros resultantes da superposição de perfis e motivos diferentes? $\mathrm{E}$, ainda para maior estranheza, não se vê, em toda a fachada, o menor 

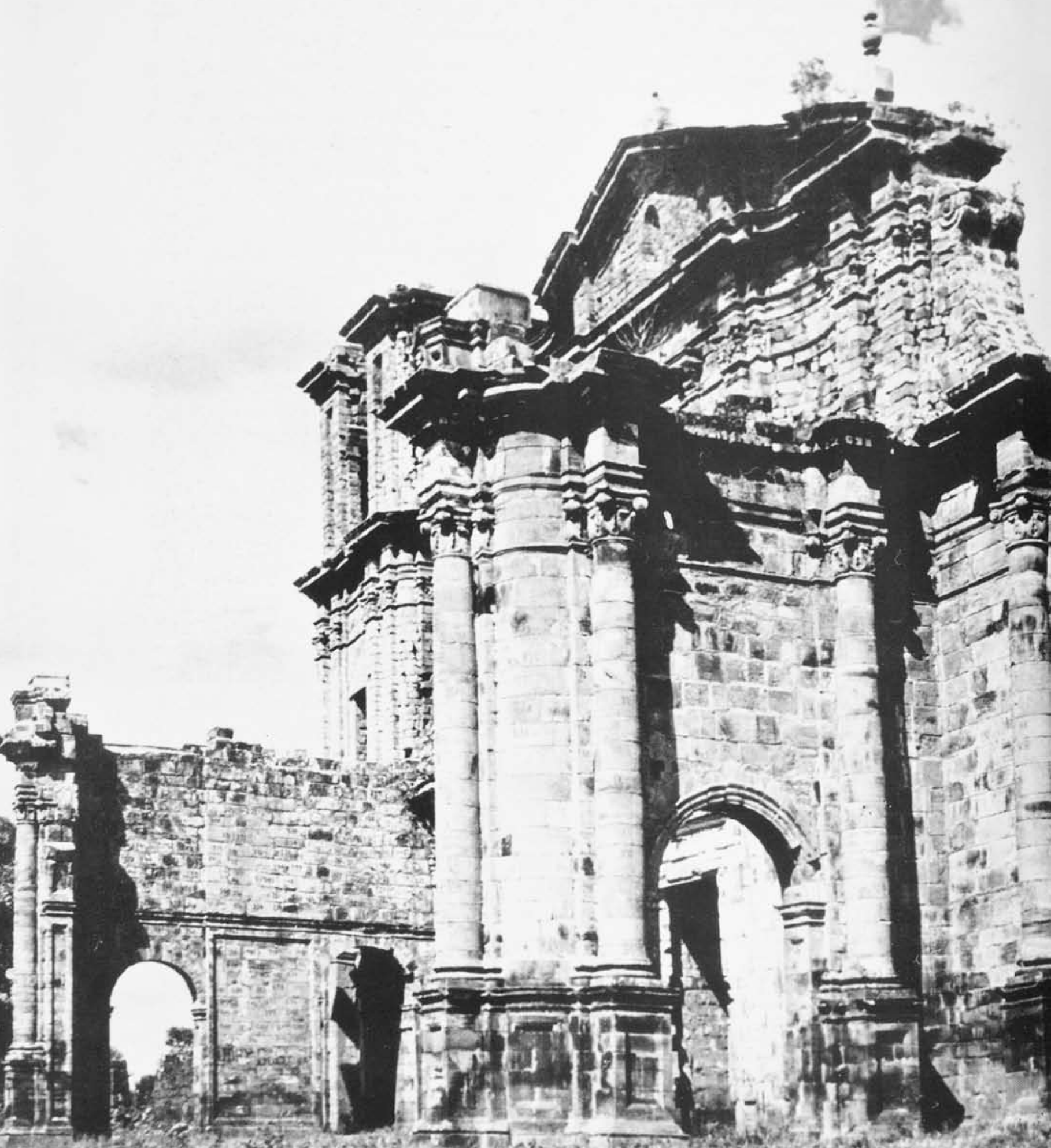

2.3. 3 i a

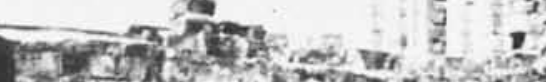

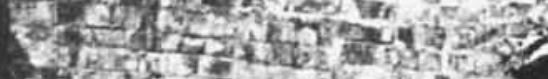

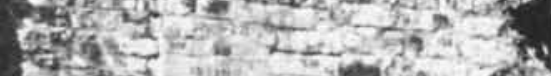
18 in B. जo A.

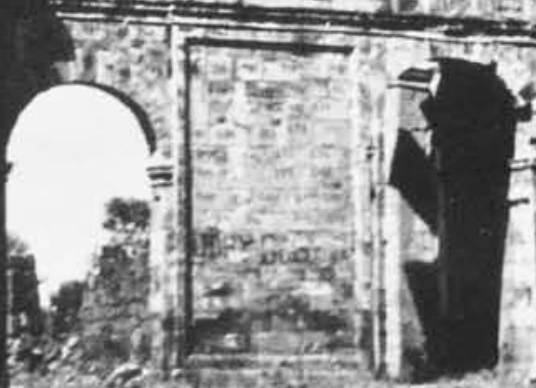

A.

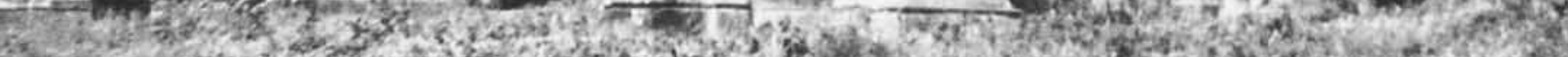

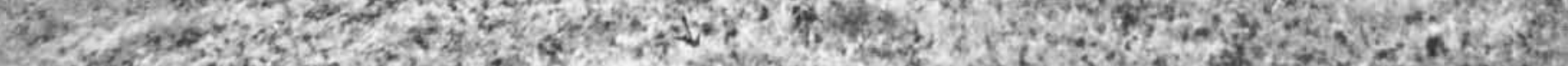

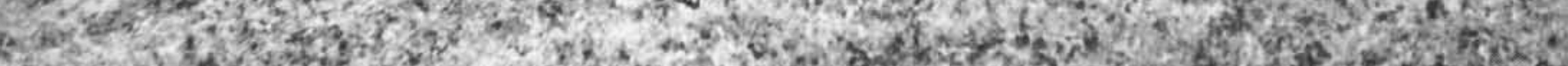

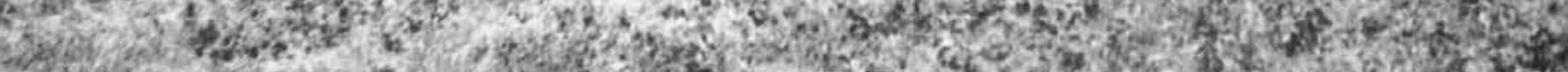


Fig. 38: Aspecto atual das ruínas da igreja do antigo Povo de São Miguel, no Rio Grande do Sul.

vestígio de amarração da cobertura do pórtico, a qual, apoiada sobre o primeiro entablamento, deveria forçosamente cobrir as bases e parte dos fustes da ordem superior de pilastras. Ou teriam sido os trabalhos interrompidos com as lutas (1752) que precederam a expulsão e o definitivo abandono? E qual teria sido a obra de João Batista Primoli o "irmão incomparável, infatigável [...] o arquiteto, o mestre, o pedreiro da obra [...] que anda sempre ocupado aqui e acolá a ver, a examinar, alevantar planos", conforme se lê na carta do padre Carlos Gervasoni ao padre Comini, de 9 de junho de 1729 - a igreja propriamente, como suponho, igreja cuja fachada apresenta muita semelhança com a da antiga catedral de Buenos Aires, de autoria dele e de Bianchi, e que, por sinal, não tem nártex, ou o pórtico que, pelos seus ares "neoclássicos", induziu o ilustre professor Sr. Miguel Solá a atribuir a todo o conjunto a classificação por demais vaga de "greco-romano", quando a igreja, na verdade, é toda ela de estilo barroco (fig. 39). Ou teria trabalhado em ambos - o que parece pouco provável, convindo, no entanto, apurar-se ao certo a data de sua morte, que ocorreu em terras missioneiras, como também a do irmão Carlos Frank, diretor das construções. Cabe, pois, aos estudiosos do assunto, entre os quais o douto Sr. Aurélio Porto e o padre Luiz Gonzaga Jaeger, S. J., elucidar em definitivo a questão.

Com certo constrangimento, verificamos ter sido todo o conjunto, tanto externa como internamente, revestido por reboco de tabatinga, de poucos milímetros de espessura e aplicado diretamente sobre o grés, encobrindo-se assim a textura e a cor. Revestimento que ainda se conserva perfeito em muitas partes protegidas da construção e é, sem dúvida, contemporâneo dela, pois o aparelho das pilastras da fachada mostra muito claramente, em alguns trechos, que não se pretendia deixá-lo aparente, notando-se, também, nos arcos da nave, de um lado, aduelas de cantaria com o perfil da arquivolta e, do outro, alvenaria de tijolo já sem moldura nenhuma.

Ao contrário das outras igrejas missioneiras, em que o peso da cobertura era aliviado por duas ordens de colunas de madeira ou de pedra, aqui ainda se acham relativamente bem conservados com as suas arcadas, a nave e os colaterais. Do colégio estão de pé alguns panos mal ajustados de paredes e encontram-se, espalhadas por toda a redondeza, inúmeras bases - todas com o característico encaixe quadrangular pertencentes aos pilares do alpendrado que circundava as casas dos índios e cujo intercolúnio era de $5 \mathrm{~m}$. 10, conforme observamos do lado direito da praça, na esquina mais próxima da igreja.

Em São Lourenço, foram encontradas duas peças do antigo lavatório da sacristia, o mesmo reproduzido numa gravura da obra já citada de Demersay e também descrito por Hemetério Veloso, que ainda o conheceu inteiro: a bacia alongada que constitui com o suporte central uma pedra só, e as duas cabeças de águia encimadas pela coroa - "marca registrada" da casa dos Habsburgs. Enquanto que na igreja de São Borja ainda se conserva, além da pia de batismo e de várias imagens, como também ocorre na de São Luís (fig. VII l), talvez o último dos numerosos retábulos das sete igrejas 


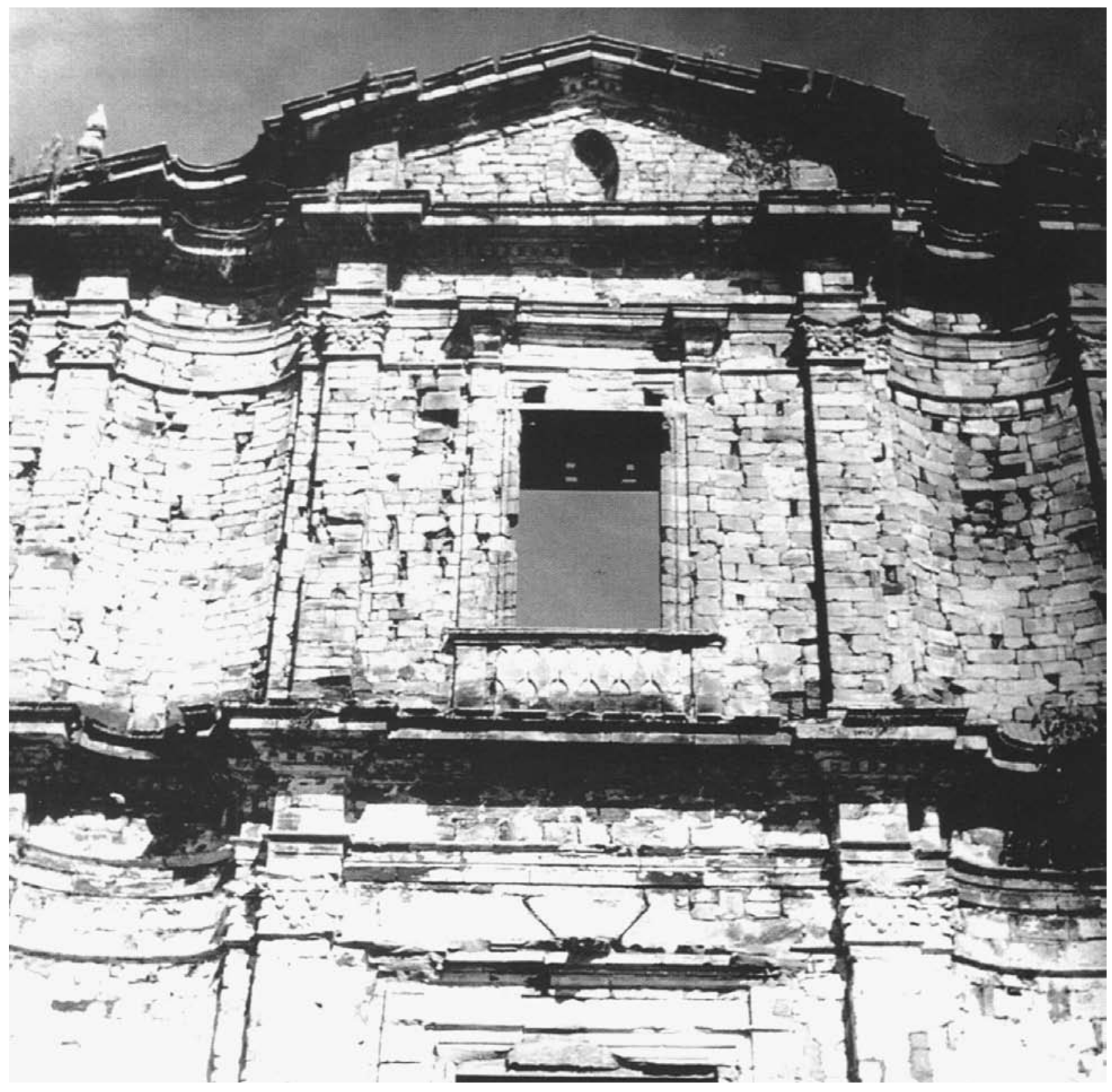


Fig. 39: Pormenor do frontispício barroco da igreja missionária de São Miguel.

Na próxima página, fig. 40: Antigo retábulo da igreja de São Borja das Mlssões.

missioneiras, pela valiosíssima não só por este motivo, como ainda, por ser de sabor a um tempo "crioulo" e jesuítico (fig. 41).

Finalmente, cabe uma referência ao curioso túmulo circular de São Nicolau, hoje desmoronado, de que a obra importante do padre Pablo Hernandez, S. J., reproduz uma fotografia tirada em 1904, com esta legenda: "Túmulo [...] que parece del tiempo de los jesuítas, y remeda um estylo egípcio ó incásico”, e sobre o qual o professor Miguel Solá, que seguramente não esteve em São Nicolau, faz as seguintes referências, aparentemente corretas: "[...] por su completo caracter indígena hemos mencionado el edificio circular que existe en el cementerio de S. Nicolás [...] flanqueado por dos figuras de talla primitiva. Las jambas y el dintel de la puerta son monolíticos y reticulados e impresionan en sentido incaico”. Estranhávamos que H. Veloso, sempre tão preciso e minucioso nas suas informações, deixasse de fazer qualquer menção a esse monumento. E, com efeito, apuramos tratar-se simplesmente do túmulo de um certo capitão Andrade e que foi construído, em fins do século passado, por um italiano conhecido pela alcunha de "gringo Ângelo”. Quem nos prestou estas informações foi o Sr. Alexandre Correia Machado, de 77 anos de idade; e como indagássemos se esse italiano era empreiteiro e se tinha operários índios a seu serviço, declarou-nos que o "gringo" fazia o serviço ele próprio com as mãos e afirmou categoricamente tê-lo visto trabalhar. E, realmente, Hermetério Veloso cita o caso "tristíssimo" do capitão Andrade, assassinado em 1886, juntamente com a esposa, tendo sido os criminosos queimados pela população enfurecida.

Aliás, esse túmulo, de aspecto grosseiro, não poderia mesmo ter qualquer relação com os grandes pedestais esplendidamente "perfilados” (fig. VIIm), últimos vestígios autênticos da igreja dos jesuítas.

Lúcio Costa (1902-1998) foi arquiteto, urbanista e professor. Pioneiro da arquitetura modernista no Brasil, ficou conhecido mundialmente pelo projeto do Plano Piloto de Brasília. Foi também colaborador e diretor do Instituto do Patrimônio Histórico e Artístico Nacional, o IPHAN. 



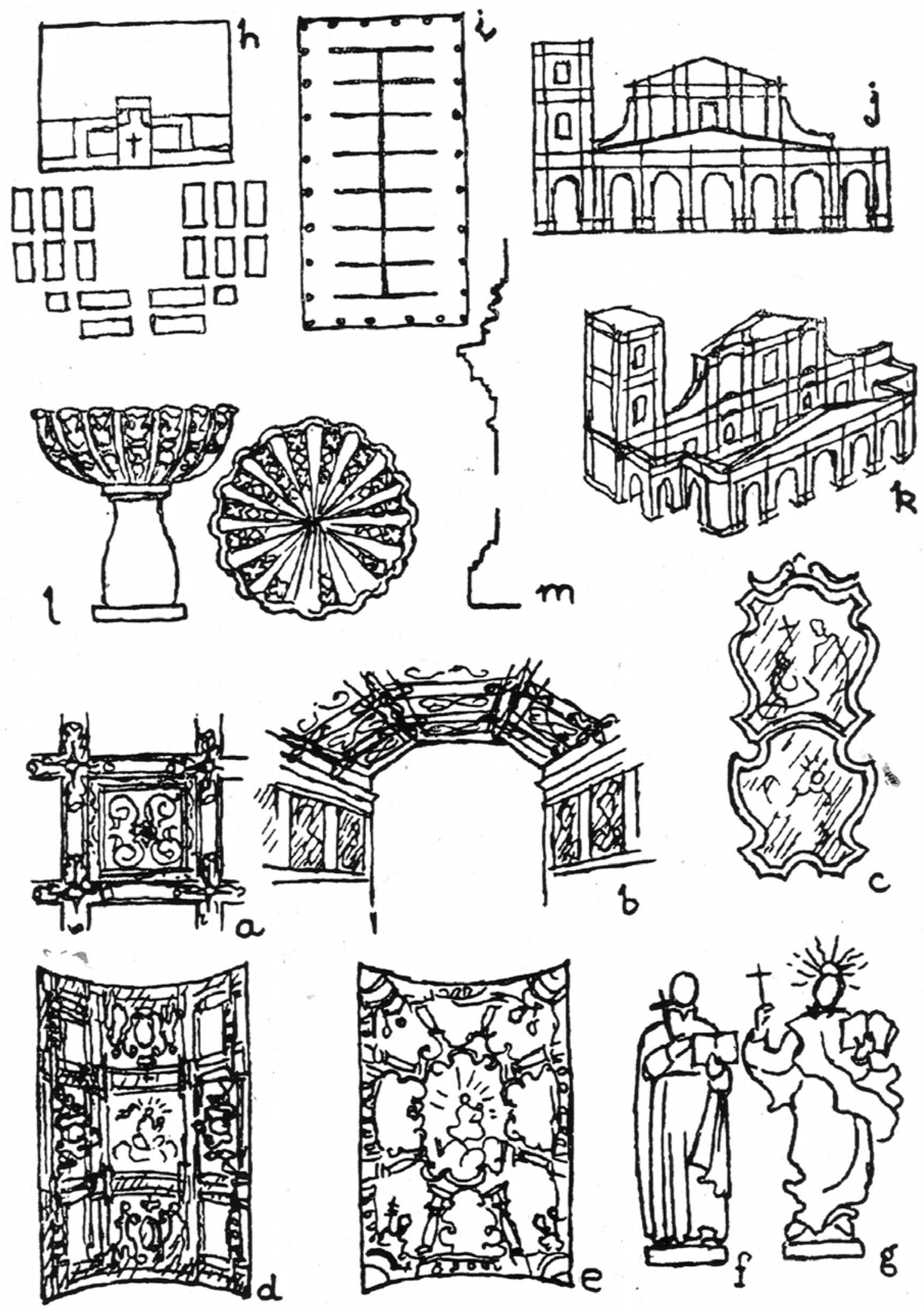

